\title{
Effect of SOFC Interconnect-Coating Interactions on Coating Properties and Performance
}

\section{Final Report}

U.S. Department of Energy

Office of Science Financial Assistance Program

Experimental Program to Stimulate Competitive Research (EPSCoR)

Building EPSCoR-State/National Laboratory Partnerships

DOE BES Project Manager: Timothy Fitzsimmons

Phone: (301) 903-9830

E-mail: tim.fitzsimmons@science.doe.gov

DOE NETL Project Manager: Briggs White

Phone: (304) 285-5437

E-mail: Briggs.White@netl.doe.gov

Participating DOE Laboratory

Pacific Northwest National Laboratory

Primary contact: Jeffry Stevenson

Contract Number: DE-FG02-08ER46497

Start Date: 15 June 2008

End Date: 14 June 2012

Jeffrey W. Fergus

Auburn University

Materials Research and Education Center

275 Wilmore Laboratories

Auburn, AL 36849

Phone: (334) 844-3405; Fax: (334) 844-3400

E-mail: jwfergus@eng.auburn.edu

05 September 2012 


\section{Executive Summary}

The high operating temperature of solid oxide fuel cells (SOFCs) provides good fuel flexibility which expands potential applications, but also creates materials challenges. One such challenge is the interconnect material, which was the focus of this project. In particular, the objective of the project was to understand the interaction between the interconnect alloy and ceramic coatings which are needed to minimize chromium volatilization and the associated chromium poisoning of the SOFC cathode.

This project focused on coatings based on manganese cobalt oxide spinel phases $(\mathrm{Mn}, \mathrm{Co})_{3} \mathrm{O}_{4}$, which have been shown to be effective as coatings for ferritic stainless steel alloys. Analysis of diffusion couples was used to develop a model to describe the interaction between $(\mathrm{Mn}, \mathrm{Co})_{3} \mathrm{O}_{4}$ and $\mathrm{Cr}_{2} \mathrm{O}_{3}$ in which a two-layer reaction zone is formed. Both layers form the spinel structure, but the concentration gradients at the interface appear like a two-phase boundary suggesting that a miscibility gap is present in the spinel solid solution. A high-chromium spinel layer forms in contact with $\mathrm{Cr}_{2} \mathrm{O}_{3}$ and grows by diffusion of manganese and cobalt from the coating material to the $\mathrm{Cr}_{2} \mathrm{O}_{3}$. The effect of coating composition, including the addition of dopants, was evaluated and indicated that the reaction rate could be decreased with additions of iron, titanium, nickel and copper.

Diffusion couples using stainless steel alloys (which form a chromia scale) had some similarities and some differences as compared to those with $\mathrm{Cr}_{2} \mathrm{O}_{3}$. The most notable difference was that the highchromium spinel layer did not form in the diffusion couples with stainless steel alloys. This difference can be explained using the reaction model developed in this project. In particular, the chromia scale grows at the expense of the alloy, the high-chromia layer grows at the expense of chromia scale and the high-chromia layer is consumed by diffusion of chromium into the coating material. If the last process (dissolution of high-chromium spinel phase) is faster than the second process (formation of highchromium spinel phase), the high-chromium layer may be consumed. The other important result of this mechanism is that it could result in a constant scale thickness if the scale forms at the same rate as it is consumed. This helps to explain the unexpected observation that the area specific resistance (ASR) of a SOFC with a $(\mathrm{Mn}, \mathrm{Co})_{3} \mathrm{O}_{4}$-coated ferritic stainless steel cathode becomes constant after long exposures.

The project also evaluated the possibility of reducing the chromium content in a stainless steel alloy using experimental alloys. The conclusion of this evaluation is that at least $17-18 \%$ chromium is needed for good oxidation resistance is needed even if the alloy is coated with a spinel coating.

Additional details on these findings are provided in a later section of this report and in the publications listed below. 


\section{Requested Information}

Number of graduate students trained: $\mathbf{2}$

- Yingjia Liu

- Yu Zhao (partial support $\sim 20 \%$ - also worked on NSF project)

Post-doctoral fellows who worked on the project: 3

- Kangli Wang

- Dileep Kumar C.J.

- Jason Ganley

Undergraduate students who worked on the project: 5

- Margaux Blanchard

- Adam Dekich

- Susan Matassa

- Lynne Riherd

- Alexander Smith

- William Tilson

\section{Publications}

\section{Journal Papers}

1. A. Purwanto, A. Fajar, H. Mugirahardjo, J.W. Fergus and K. Wang, "Cation Distribution in Spinel (Mn, $\mathrm{Co}, \mathrm{Cr})_{3} \mathrm{O}_{4}$ at Room Temperature," Journal of Applied Crystallography 43 (2010) 394-400.

2. J.W. Fergus, "Synergism in the Design of Interconnect Alloy-Coating Combinations for Solid Oxide Fuel Cells," Scripta Materialia 65 (2011) 73-77.

3. K. Wang, Y. Liu and J.W. Fergus, "Interactions between SOFC Interconnect Coating Materials and Chromia," Journal of the American Ceramic Society 94[12] (2011) 4490-4495.

4. Dileep Kumar C.J., A. Dekich, Y. Liu, W. Tilson, J. Ganley and J.W. Fergus, "Transition Metal Doping of Manganese Cobalt Spinel Oxides for Coating SOFC Interconnects," in preparation - to be submitted to the Journal of the American Ceramic Society

5. Y. Liu and J.W. Fergus, "Electrical Properties, Cation Distribution and Thermal Expansion of Manganese Cobalt Chormite $(\mathrm{Mn}, \mathrm{Co})_{3-x} \mathrm{Cr}_{x} \mathrm{O}_{4}$ Spinels," in preparation - to be submitted to the Journal of the American Ceramic Society 


\section{Book Chapter}

1. J.W. Fergus, "Solid Oxide Fuel Cells," in Electrochemical Technologies for Energy Storage and Conversion, R.-S. Liu, X. Sun, H. Liu, L. Zhang and J. Zhang (Eds.) (Wiley-VCH, 2012) 671-700.

(Although not a direct result of this project, work on the project contributed to the chapter)

\section{Presentations (with no proceedings paper)}

1. J.W. Fergus, "Alloys and Coatings for Solid Oxide Fuel Cell Interconnects," National Nuclear Energy Agency (BATAN), Serpong, Indonesia, 19 May 2009.

2. J.W. Fergus, "SOFC Interconnect Alloys and Coatings," Nanyang Technological University, Singapore, 22 May 2009.

3. J.W. Fergus, "Interconnect-Coating Interactions: Mn-Co Spinel Oxides," $10^{\text {th }}$ Annual SECA Workshop, Pittsburgh, PA, 15 July 2009.

4. J.W. Fergus, "Materials Degradation in Solid Oxide Fuel Cells," National Research Council, National Research Council Institute for Fuel Cell Innovation, Vancouver, BC, 28 April 2010.

5. J.W. Fergus, "Materials Degradation in Solid Oxide Fuel Cells," Invited presentation for Symposium on Assessing Environmental Degradation, 2010 ASM Annual Symposium, GE Global Research, Niskayuna, NY, 19 May 2010.

6. J.W. Fergus, "Interconnect-Coating Interactions: Transition Metal Spinel Oxides," $11^{\text {th }}$ Annual SECA Workshop, Pittsburgh, PA, 28 July 2010.

7. J.W. Fergus, Y. Liu and Y. Zhao, "Degradation of Manganese Cobalt Spinel SOFC Interconnect Coatings,"TMS 2011 Annual Meeting, San Diego, CA, 01 March 2011.

8. J.W. Fergus, "Interconnect-Coating Interactions: Transition Metal Spinel Oxides," $12^{\text {th }}$ Annual SECA Workshop, Pittsburgh, PA, 27 July 2011.

\section{Conference Proceedings Papers}

1. J. Fergus, K. Wang, Y. Liu, "Phase Equilibria in Spinel Coatings for Solid Oxide Fuel Cell Interconnects," Materials Science \& Technology (MS\&T) 2009 (2009) 312-321. (MS\&T 2009, Pittsburgh, PA)

2. J. Fergus, K. Wang and Y. Liu, "Interactions between $(\mathrm{Mn}, \mathrm{Co})_{3} \mathrm{O}_{4}$ SOFC Interconnect Coating Materials and Chromia," in Supplemental Proceedings: Volume 2: Materials Characterization, Computation, Modeling and Energy (The Minerals, Metals \& Materials Society, 2010) 473-480. (TMS 2010 Annual Meeting, Seattle, WA) 
3. J.W. Fergus, K. Wang and Y. Liu, "Effect of Titanium and Iron Additions on the Transport Properties of Manganese Cobalt Spinel Oxide," Ceramic Transactions 227 (2011) 33-37. MS\&T 2010, Houston, TX)

4. J.W. Fergus, K. Wang and Y. Liu, "Transition Metal Spinel Oxide Coatings for Reducing Chromium Poisoning in SOFCs," Electrochemical Transactions 33[40] (2011) 77-84. (217 ${ }^{\text {th }}$ Meeting of the Electrochemical Society, Las Vegas, NV, 2010)

5. Y. Liu, K. Wang and J.W. Fergus, "Effect of Chromium Doping on the Crystal Structure, Electrical Conductivity and Thermal Expansion of Manganese Cobalt Spinel Oxides," Advanced in Solid Oxide Fuel Cells VII: Ceramic Engineering and Science Proceedings 32[4] (2011) 125-129. (8 ${ }^{\text {th }}$ International Symposium on SOFC, Daytona Beach, FL, 2011)

6. J.W. Fergus and Y. Zhao, "Low-Chromium Alloys for Solid Oxide Fuel Cell Interconnects," Electrochemical Transactions 35[1] (2011) 2447-2453. (SOFC XII, 220 ${ }^{\text {th }}$ Meeting of the Electrochemical Society, Montreal, Canada, 2011)

8. J.W. Fergus, Y. Liu and Y. Zhao, "Manganese Cobalt Spinel Oxide Based Coatings for SOFC Interconnects," Ceramic Transactions [Advanced in Materials Science for Environmental and Energy Technologies] (2012) in press (MS\&T 2011, Columbus, OH)

8. J.W. Fergus, Y. Zhao and Y. Liu, "Optimization of Alloy-Coating Compositions for Use as Solid Oxide Fuel Cell Interconnects," Materials Research Society Proceedings 1384 (2012) b13-22. (MRS 2011 Fall Meeting, Boston, MA)

9. Y. Liu, Dileep Kumar C.J. and J. Fergus, "Electrical Properties of Transition Metal-doped $(\mathrm{Mn}, \mathrm{Co})_{3} \mathrm{O}_{4}$ Spinels and Their Interaction with Chromia for SOFC Interconnect Coatings", Electrochemical Transactions 45[1] (2012) 421-427. (221 ${ }^{\text {st }}$ Meeting of the Electrochemical Society, Seattle, WA, 2012)

10. Dileep Kumar C.J., Y. Liu, J. Ganley, W. Tilson, A. Dekich and J. Fergus, "Transition Metal Doping of Manganese Cobalt Spinel Oxides for Coating SOFC Interconnects," in Energy Technology 2012: Carbon Dioxide Management and Other Technologies, M.D. Salazar-Villalpando, N.R. Neelameggham, D.P. Guilllen, S. Pati and G.K.Krumdick (Eds.) (The Minerals, Metals \& Materials Society, 2012) 313-319. (TMS 2012 Annual Meeting, Orlando, FL) 


\section{Current and Pending Support}

\section{Current}

Scholarships for Engineering Students from Underrepresented Groups, National Science Foundation, $\$ 599,527,08 / 08-07 / 14$, J.W. Fergus (PI), S. Scott-Harris (Co-PI).

Investigation of Lithium-Ion Polymer (Li-P) Batteries Degradation under Thermal Fatigue, ARDI, S.I. Choe (PI) and J.W. Fergus (Co-PI), \$397,483, 02/01/11-1/31/13.

\section{Pending}

Scholarships for Engineering Students from Underrepresented Groups, National Science Foundation, $\$ 599,527,08 / 08-07 / 14$, J.W. Fergus (PI), S. Scott-Harris (Co-PI).

REU Site: Interdisciplinary Green Energy Research Experiences for Next Generation Scientists and Engineers, National Science Foundation, \$438,261, 10/01/13-05/31/17, J.W. Fergus (PI), C. Schnittka Co$\mathrm{PI})$.

\section{Submitted in Near Future}

GOALI project with NexTech Materials on SOFC coating materials, National Science Foundation, $\sim \$ 300,000,10 / 01 / 13-09 / 30 / 16$, J.W. Fergus (PI).

\section{Cost Status}

Cost status will be provided by the sponsored programs office. 


\section{Detailed Summary of Accomplishments}

\section{Introduction}

The high operating temperature of solid oxide fuel cells (SOFCs), which provides their excellent fuel flexibility, can lead to degradation of individual fuel cell components. One form of degradation is chromium poisoning of the cathode, which results from volatilization of chromium from the chromia scale formed on alloys used for the interconnect. The amount of chromium volatilization, and thus the associated cell poisoning, can be minimized by applying a ceramic coating to the alloy surface. One promising coating material system is the spinel $(\mathrm{Mn}, \mathrm{Co})_{3} \mathrm{O}_{4}[1-4]$, which has been shown to reduce chromium volatilization $[5,6]$.

Although chromium can form a spinel phase with other transition metals, chromium has not been observed in the coating during use in a SOFC $[7,8]$. However, with time, interaction of the coating with the chromia scale or with other SOFC components can lead to changes in the coating composition, which can affect properties and thus performance. The purpose of this work is to study the interaction between chromia and potential interconnect coating materials to provide the information needed to design effective coatings for long-time SOFC operation.

The project has addressed three aspects of coating properties and performance: i) thermodynamics, ii) transport properties and iii) physical properties. The thermodynamic aspects include phase equilibria, crystal structure stability and chemical activity. The transport properties evaluated include electrical conductivity and diffusion rates. The physical properties are those that are important for coating performance, such as the coefficient of thermal expansion. These aspects have been evaluated for the original coating composition and for compositions resulting from interaction of the coating with other fuel cell components by preparing bulk analogues of the compositions expected after the interaction occurs. Characterization of these bulk analogues has provided valuable information for evaluating changes in the performance after interaction with other components and insight on compositions with potentially improved performance. A model developed to describe the reaction between chromia and spinel oxides helps to explain recently reported results of a constant area specific resistance in SOFCs operated for long periods of times. 


\section{Undoped $(\mathrm{Mn}, \mathrm{Co})_{3} \mathrm{O}_{4}$}

\section{$M n: C o=1: 1$}

The focus of the project was on the spinel $(\mathrm{Mn}, \mathrm{Co})_{3} \mathrm{O}_{4}$, which is the most promising coating material identified by Pacific Northwest National Laboratory (PNNL). Initially, the interaction of this coating with chromia at temperatures higher than those used in SOFC applications was used to accelerate the interaction and overcome kinetic limitations at SOFC operating temperatures.

The surface of the $\mathrm{Mn}_{1.5} \mathrm{Co}_{1.5} \mathrm{O}_{4}$ prepared by sintering at $1200^{\circ} \mathrm{C}$ for 24 hours is shown in Figure 1. After reaction with $\mathrm{Cr}_{2} \mathrm{O}_{3}$ at $1200^{\circ} \mathrm{C}$ a chromium-rich layer formed on the surface. Figure 2 shows the surface of the reaction layer after removal of the $\mathrm{Cr}_{2} \mathrm{O}_{3}$ from the surface (the white particles are residual $\left.\mathrm{Cr}_{2} \mathrm{O}_{3}\right)$. The composition of this surface layer reached $\mathrm{Mn}_{0.4} \mathrm{Co}_{0.6} \mathrm{Cr}_{2} \mathrm{O}_{4}$ and the surface becomes very faceted which is indicative of growth towards the $\mathrm{Cr}_{2} \mathrm{O}_{3}$. Reaction was also observed in regions not in contact with the $\mathrm{Cr}_{2} \mathrm{O}_{3}$ - presumably due to vapor phase transport by $\mathrm{Cr}^{6+}$-containing species such as $\mathrm{CrO}_{3}$ or $\mathrm{CrO}_{2}(\mathrm{OH})_{2}$, which have high vapor pressures. Although the amount of reaction is significant, the morphology is very different. There are no facets and there appears to be growth, and possibly melting, at the grain boundaries.

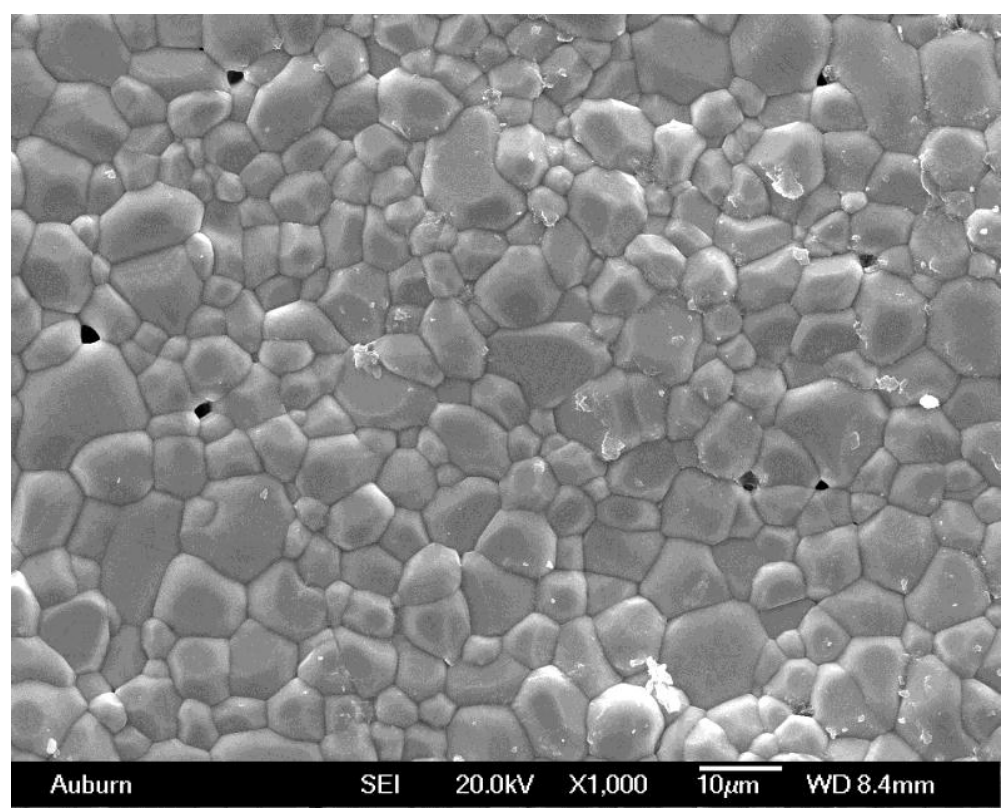

Figure 1. Surface of $\mathrm{Mn}_{1.5} \mathrm{Co}_{1.5} \mathrm{O}_{4}$ prepared by sintering in air at $1200^{\circ} \mathrm{C}$ for 24 hours 

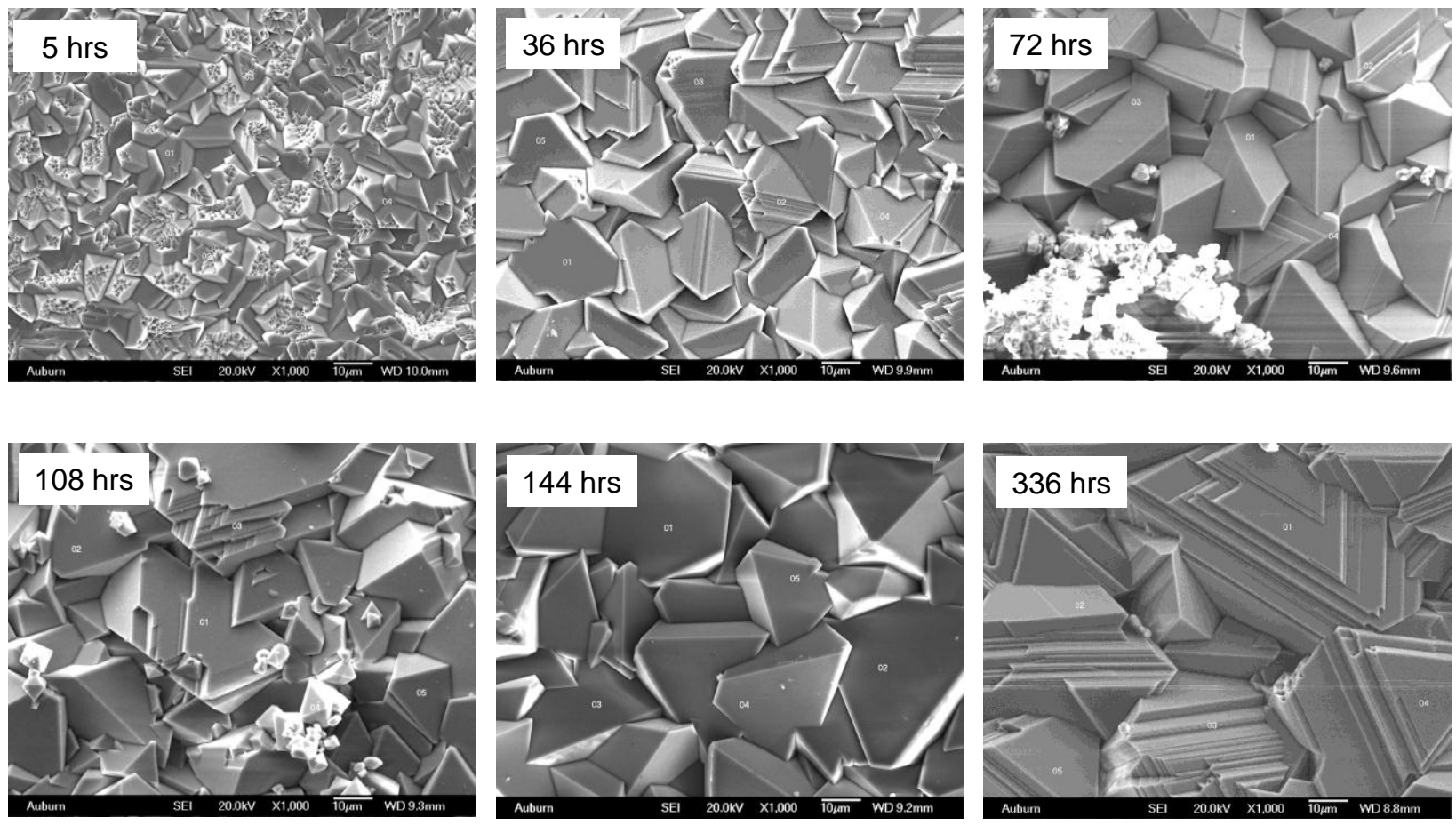

Figure 2. Surface of $\mathrm{Mn}_{1.5} \mathrm{Co}_{1.5} \mathrm{O}_{4}$ after reaction with $\mathrm{Cr}_{2} \mathrm{O}_{3}$ at $1200^{\circ} \mathrm{C}$.
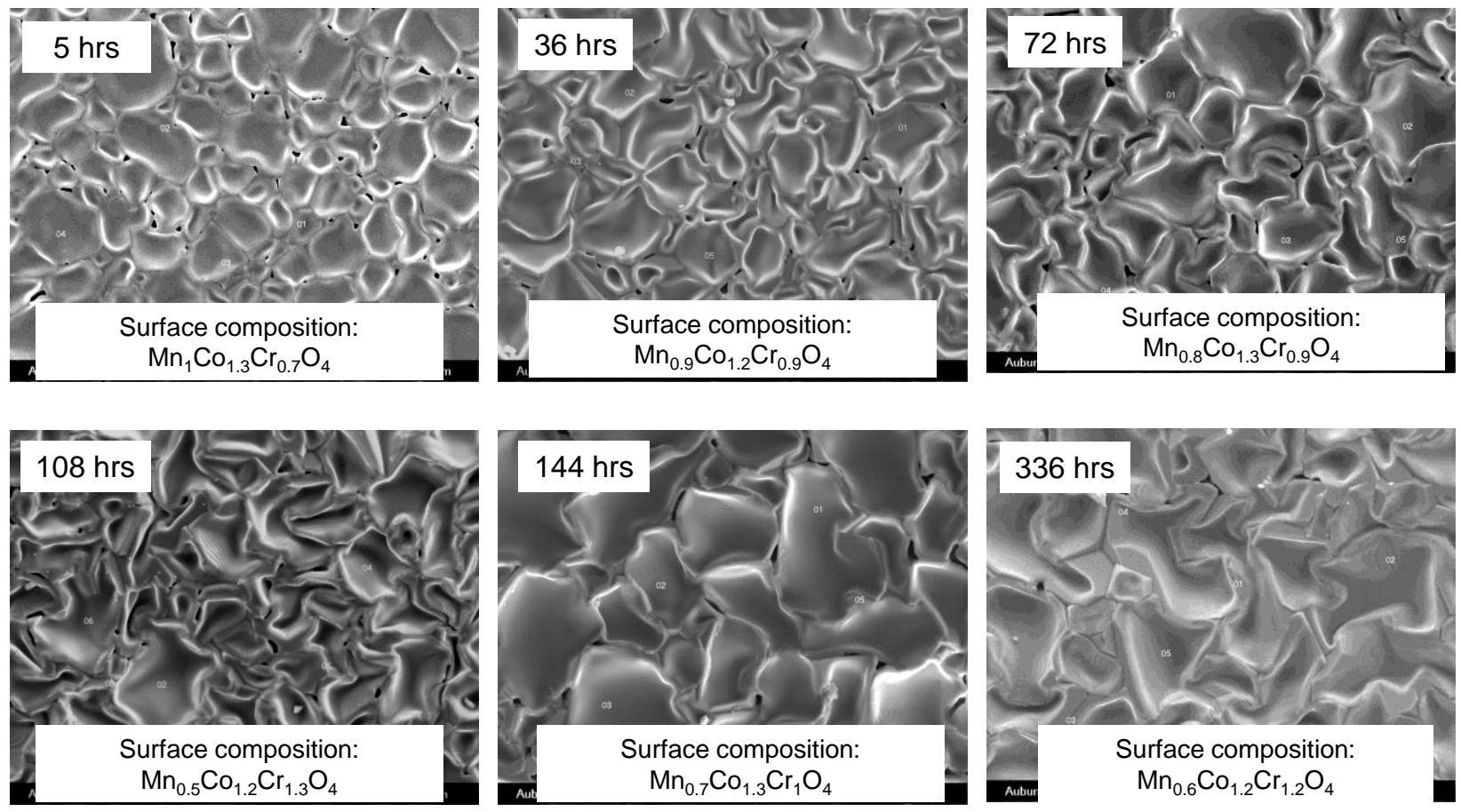

Figure 3. Surface of $\mathrm{Mn}_{1.5} \mathrm{Co}_{1.5} \mathrm{O}_{4}$ after reaction with $\mathrm{Cr}$-containing vapor at $1200^{\circ} \mathrm{C}$. 
The cross-section of the samples reacted for 336 hours at $1200^{\circ} \mathrm{C}$ are shown along with the asprepared $\mathrm{Mn}_{1.5} \mathrm{Co}_{1.5} \mathrm{O}_{4}$ in Figure 4. A dense layer of similar thickness formed in both cases and these dense regions correspond to the increased chromium content shown in Figure 5 . Although the penetration depth of chromium is similar in both cases, the surface composition is very different. For the regions in contact with chromia, the chromium composition reached a maximum of two chromium per formula unit, i.e. $(\mathrm{Mn}, \mathrm{Co}) \mathrm{Cr}_{2} \mathrm{O}_{4}$, at which point, presumably, all the manganese and cobalt have a valence of $2+$ and the chromium has valence of $3+$ to obtain the required average valence of $2.67+$. Such a layer did not form in the regions that grew by vapor phase transport and the faceted structure did not form from the vapor phase even after long exposures. It was possible to obtain the maximum chromium content through vapor phase transport by enclosing a $\mathrm{Mn}_{1.5} \mathrm{Co}_{1.5} \mathrm{O}_{4}$ sample in a $\mathrm{Cr}_{2} \mathrm{O}_{3}$ chamber as shown schematically in Figure 6. The scanning electron microscope (SEM) images show the transition to the faceted morphology as the chromium content approaches the maximum concentration due to the close proximity of the region to the chamber wall (i.e. the chromium source).

The behavior was similar at lower temperatures that are more typical of the operating temperature for SOFCs. The surfaces of $\mathrm{Mn}_{1.5} \mathrm{CO}_{1.5} \mathrm{O}_{4}$ after reaction with $\mathrm{Cr}_{2} \mathrm{O}_{3}$ for 72 hours in air at $1000^{\circ} \mathrm{C}, 900^{\circ} \mathrm{C}$ and $800^{\circ} \mathrm{C}$ are shown in Figure 7. The morphologies of the surfaces that had been in contact with chromia are faceted and appear similar to those at $1200^{\circ} \mathrm{C}$ indicating that they may form by the same mechanism. One notable difference is that at lower temperatures, i.e. $800^{\circ} \mathrm{C}$ (Figure 8) and $900^{\circ} \mathrm{C}$ (Figure 8), the surface compositions are lower than those observed at higher temperatures, i.e. $1000^{\circ} \mathrm{C}$ (Figure 8). This is in contrast to the results at $1200^{\circ} \mathrm{C}$, where a faceted microstructure formed only when the maximum chromium content, i.e. $(\mathrm{Mn}, \mathrm{Co}) \mathrm{Cr}_{2} \mathrm{O}_{4}$, was formed. The faceted morphology is indicative of a reaction layer formed by the diffusion of cobalt and manganese from $(\mathrm{Mn}, \mathrm{Co})_{3} \mathrm{O}_{4}$ through the reaction layer. At $1200^{\circ} \mathrm{C}$, this mechanism only occurs when the chromium content reaches the maximum in the spinel phase, i.e. $(\mathrm{Mn}, \mathrm{Co}) \mathrm{Cr}_{2} \mathrm{O}_{4}$, in which case $\mathrm{Cr}^{3+}$ ions presumable occupy the octahedral sites, so manganese and cobalt are predominantly in the tetrahedral sites with a valence of $2+$. At lower temperatures, growth controlled by cobalt and manganese diffusion, which is desirable for minimizing chromium volatility, occurs for lower chromium content. This mechanism is consistent with observations of negligible chromium in $(\mathrm{Mn}, \mathrm{Co})_{3} \mathrm{O}_{4}$ interconnect coatings during SOFC operation.

To determine the growth direction of the reaction layer, platinum marker experiments were performed in which a small amount of platinum paste was placed in the between the spinel and $\mathrm{Cr}_{2} \mathrm{O}_{3}$ prior to the diffusion experiment. The location of the platinum after the reaction indicates where the new phase forms. Figure 8 shows the cross section of $\mathrm{Mn}_{1.5} \mathrm{Co}_{1.5} \mathrm{O}_{4}$ after reaction with $\mathrm{Cr}_{2} \mathrm{O}_{3}$ for 144 
hours in air at $1000^{\circ} \mathrm{C}$. The platinum marker is located to the left of the dense high-chromium layer indicating that this layer grows to the right (i.e. toward the $\mathrm{Cr}_{2} \mathrm{O}_{3}$ ) which is consistent with the faceted morphology described above.

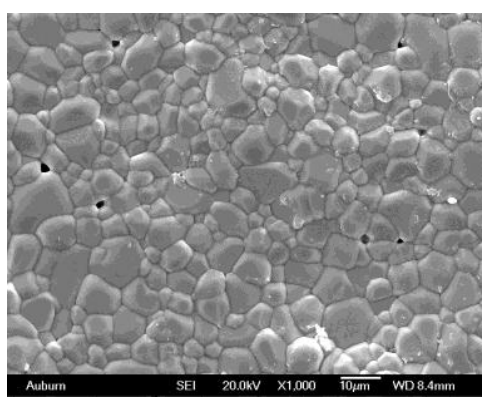

a. As-prepared spinel

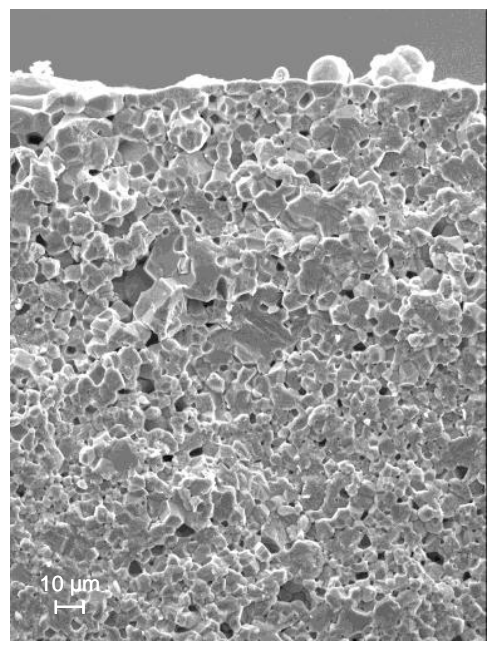

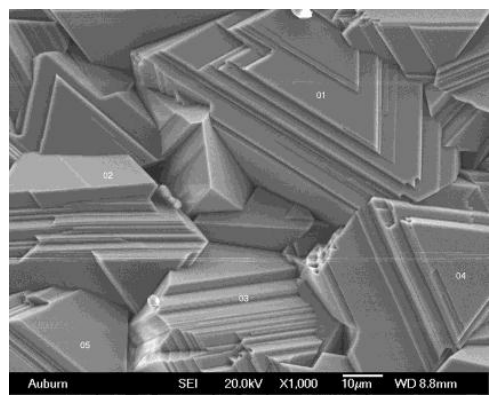

b. Spinel-chromia powder in contact c. Formed by vapor phase transport

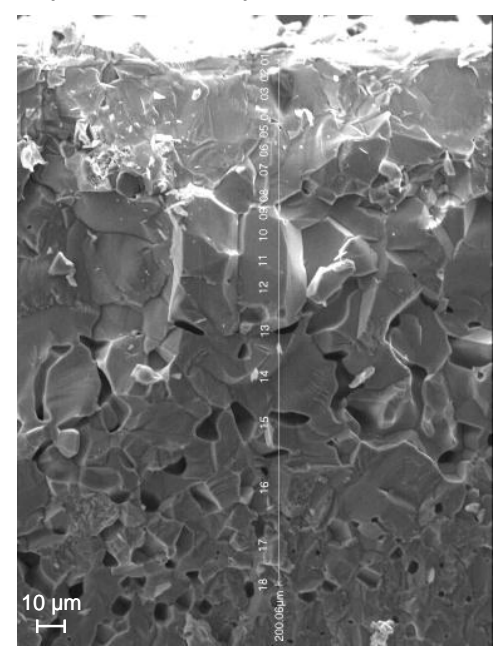

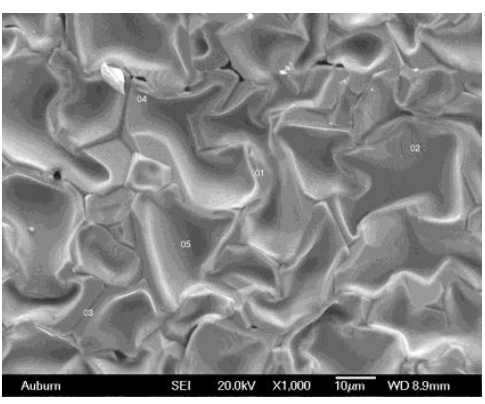

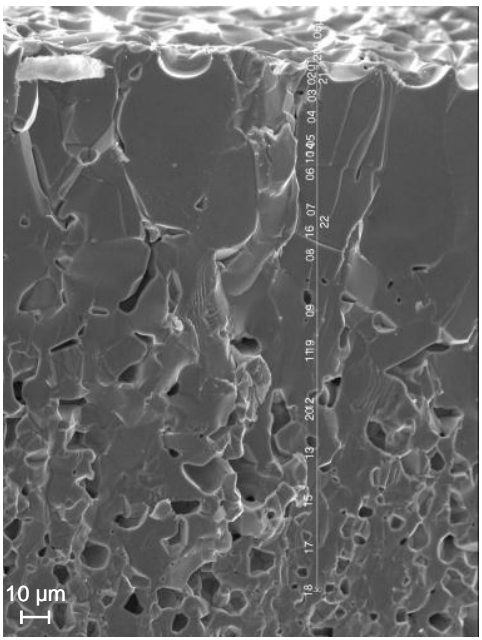

Figure 4. SEM micrographs of surfaces and cross-sections of a) as-prepared $\mathrm{Mn}_{1.5} \mathrm{Co}_{1.5} \mathrm{O}_{4}$ and after reaction in air at $1200^{\circ} \mathrm{C}$ for 336 hour b) in the region in contact with $\mathrm{Cr}_{2} \mathrm{O}_{3}$ powder and c) region not in contact with $\mathrm{Cr}_{2} \mathrm{O}_{3}$ powder.

Neutron diffraction of was performed at Oak Ridge National Laboratories to determine the site occupancy in the spinel structure. The neutron powder diffraction patterns for $\mathrm{Mn}_{1.5} \mathrm{Co}_{1.5} \mathrm{O}_{4}$ at $600^{\circ} \mathrm{C}$ and $800^{\circ} \mathrm{C}$ are shown in Figure 9. The broad background is due to the quartz sample holder. A quartz holder was used because the alternative holder was made of vanadium, which can be easily oxidized in air at high temperature and the coating material is used at the cathode where oxidizing conditions are present. Analysis of these results are summarized Table 1 and indicates that, as expected from the thermodynamic analysis of Navrotsky [9], cobalt prefers the tetrahedral site $(0.85 / 0.80 \mathrm{Co}, 0.15 / 0.21$ $\mathrm{Mn}$ at $\left.600^{\circ} \mathrm{C} / 800^{\circ} \mathrm{C}\right)$ while manganese prefers the octahedral site $(0.69 / 0.68 \mathrm{Mn}, 0.31 / 0.32$ Co at $\left.600^{\circ} \mathrm{C} / 800^{\circ} \mathrm{C}\right)$. 

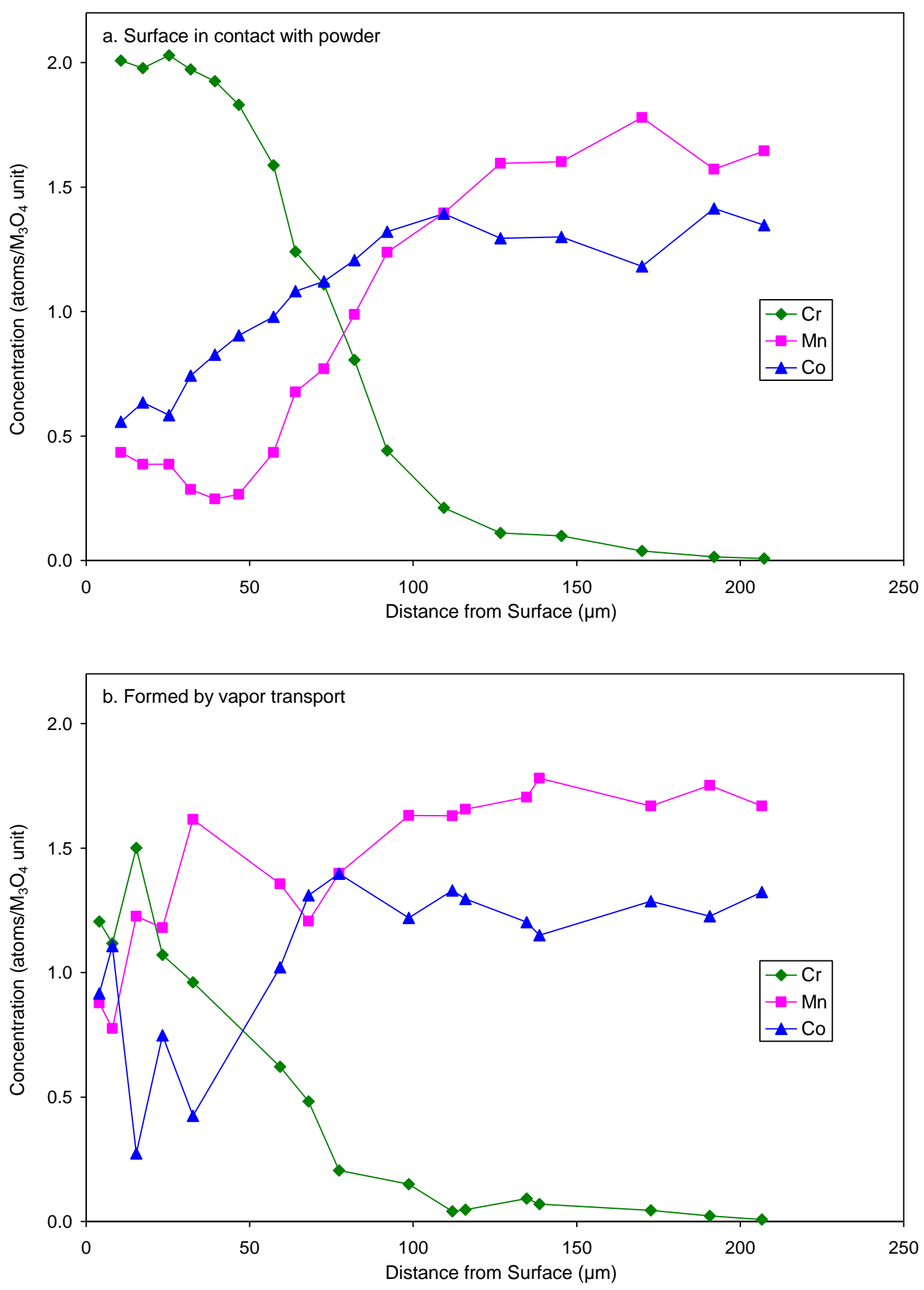

Figure 5. Composition profiles through cross-section of reaction zone as determined by EDS 


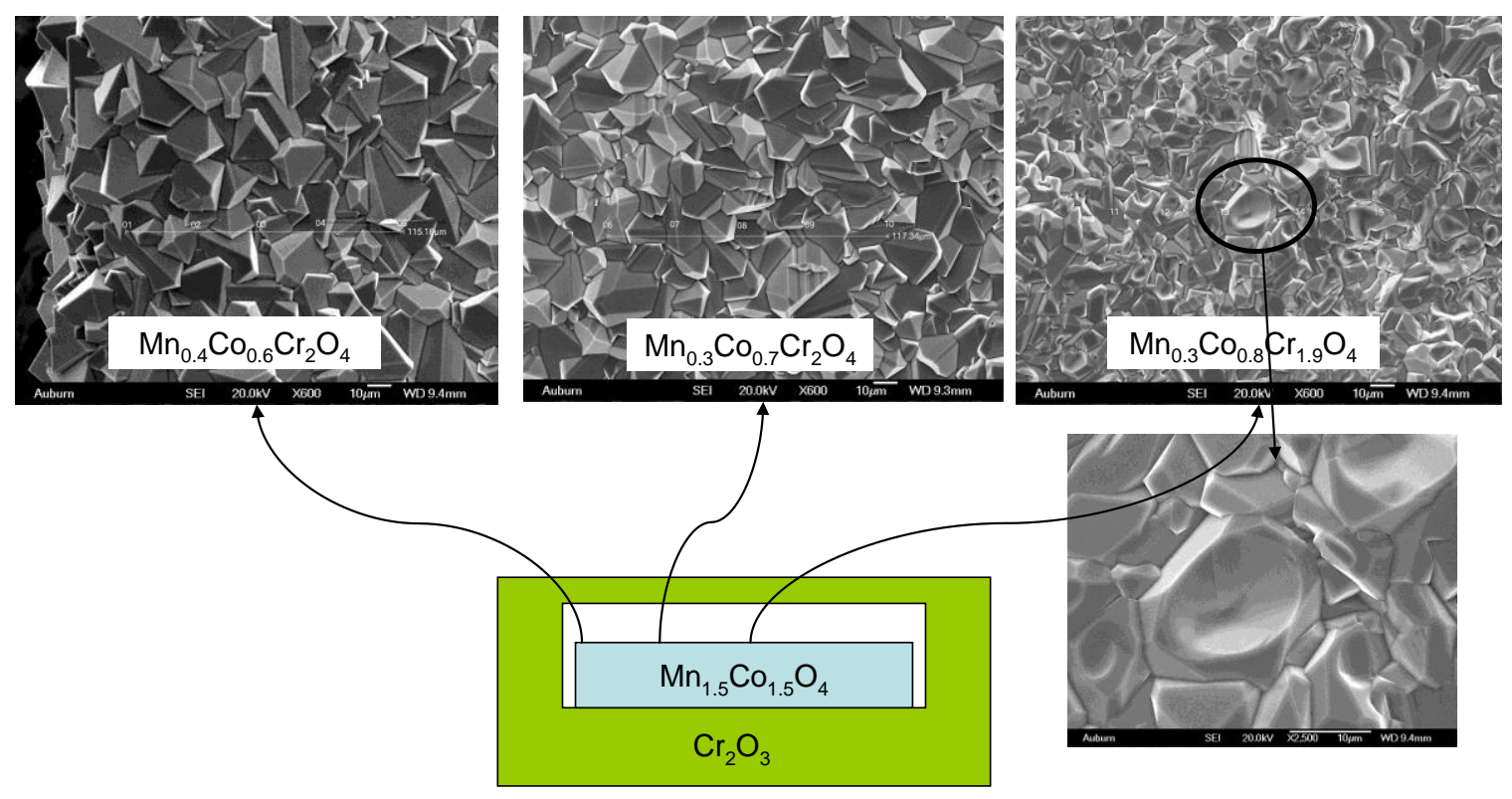

Figure 6. SEM micrographs after reaction in $\mathrm{Cr}_{2} \mathrm{O}_{3}$ chamber for 72 hours in air at $1200^{\circ} \mathrm{C}$.

Table 1 Crystal parameters of $\mathrm{Mn}_{1.5} \mathrm{Co}_{1.5} \mathrm{O}_{4}$ at high temperature $\mathrm{A}=$ Tetrahedral site; $\mathrm{B}=$ Octahedral site

\begin{tabular}{|c|c|c|c|}
\hline & $600^{\circ} \mathrm{C}$ & $800^{\circ} \mathrm{C}$ \\
\hline \multicolumn{2}{|c|}{$\mathrm{a}(\AA)$} & $8.412(9)$ & $8.433(1)$ \\
\hline \multicolumn{2}{|c|}{ U oxygen } & $0.2616(4)$ & $0.2617(6)$ \\
\hline \multirow{2}{*}{ Tetrahedral } & {$[\mathrm{Mn}]_{A}$} & 0.1506 & 0.2095 \\
\cline { 2 - 4 } & {$[\mathrm{Co}]_{\mathrm{A}}$} & 0.8494 & 0.7905 \\
\hline \multirow{2}{*}{ Octahedral } & {$[\mathrm{Mn}]_{B}$} & 0.6899 & 0.6814 \\
\cline { 2 - 4 } & {$[\mathrm{Co}]_{B}$} & 0.3101 & 0.3186 \\
\hline \multicolumn{2}{|c|}{$\mathrm{R}_{\mathrm{wp}}$} & 5.28 & 5.07 \\
\hline \multicolumn{2}{|c|}{$\mathrm{R}_{\exp }$} & 4.61 & 4.70 \\
\hline \multicolumn{2}{|c|}{$\mathrm{R}_{\mathrm{B}}$} & 3.47 & 2.67 \\
\hline \multicolumn{2}{|c|}{} & \\
\hline
\end{tabular}




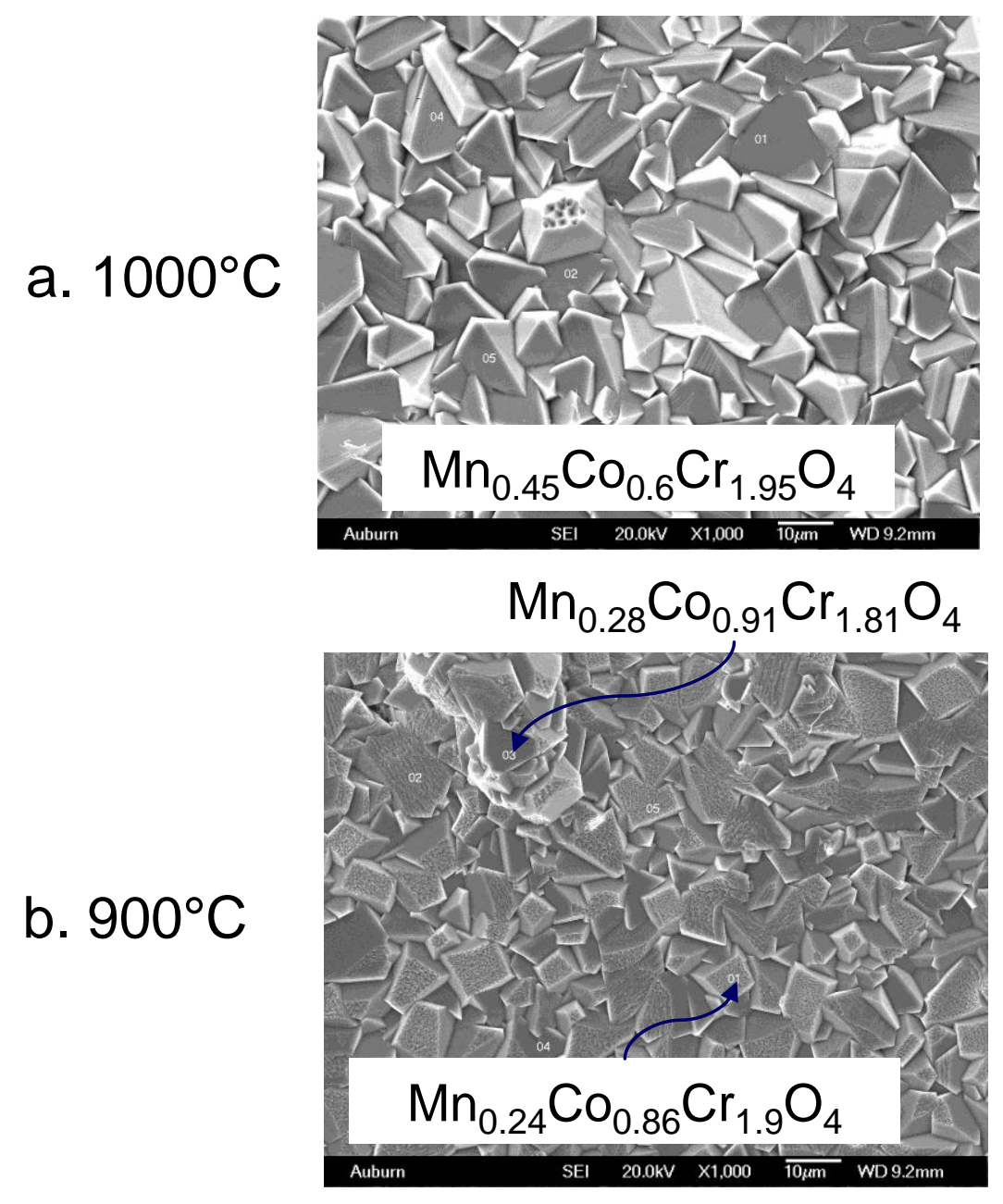

C. $800^{\circ} \mathrm{C}$

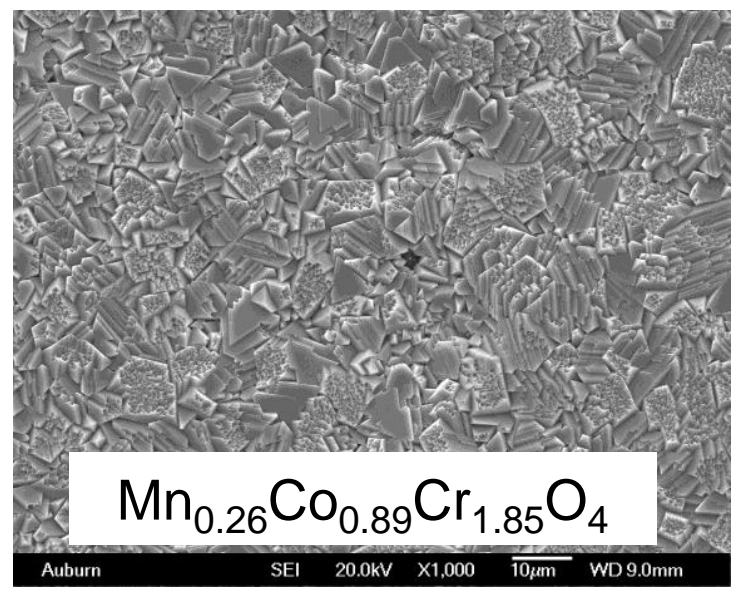

Figure 7. SEM micrographs of surfaces of $\mathrm{Mn}_{1.5} \mathrm{Co}_{1.5} \mathrm{O}_{4}$ and after reaction in air for 72 hours at (a) $1000^{\circ} \mathrm{C}$, (b) $900^{\circ} \mathrm{C}$ and (c) $800^{\circ} \mathrm{C}$. 

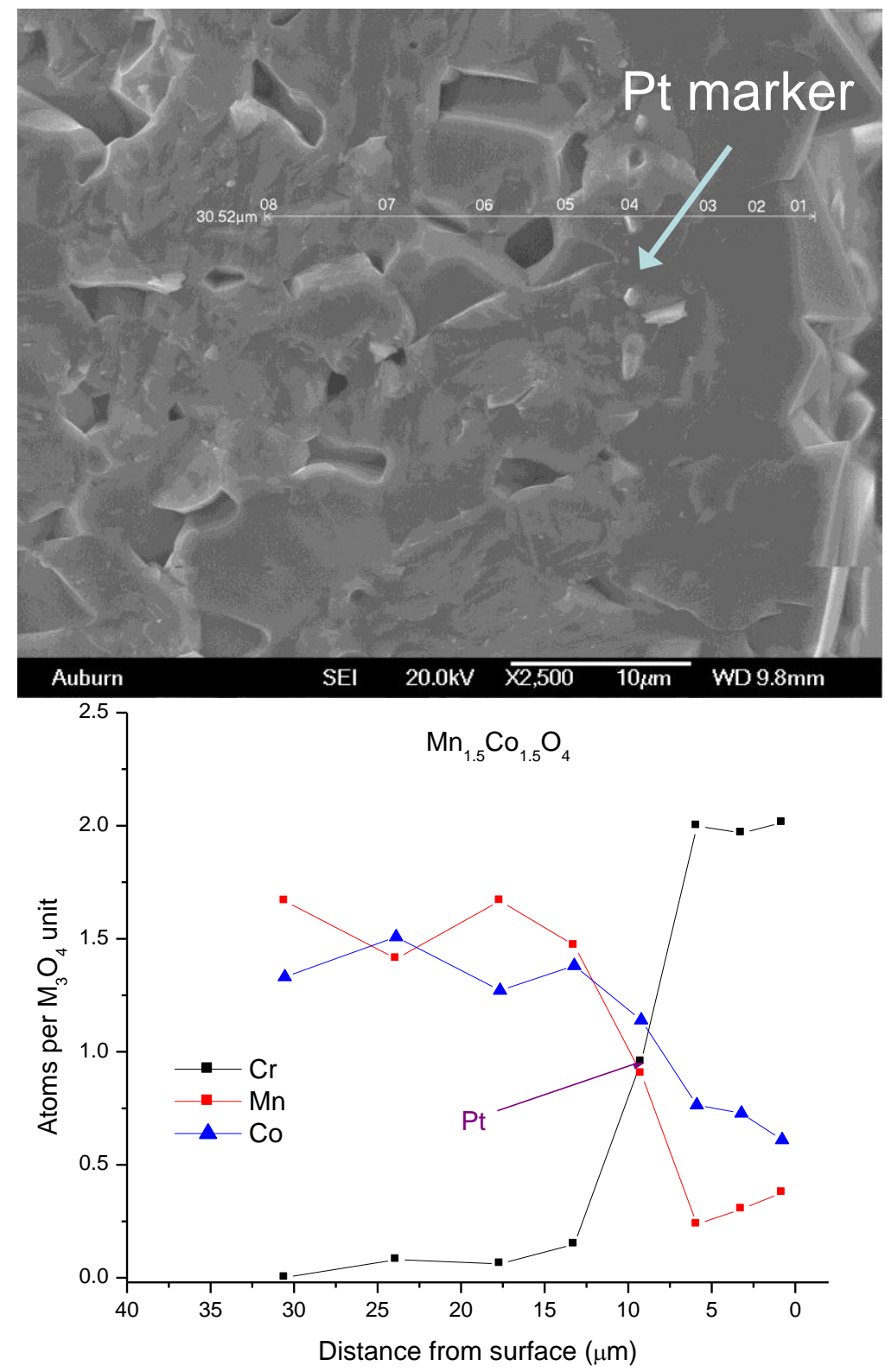

Figure 8. Cross section of $\mathrm{Mn}_{1.5} \mathrm{Co}_{1.5} \mathrm{O}_{4}$ prepared by sintering after reaction with $\mathrm{Cr}_{2} \mathrm{O}_{3}$ in air at $1000^{\circ} \mathrm{C}$ for 144 hours. 

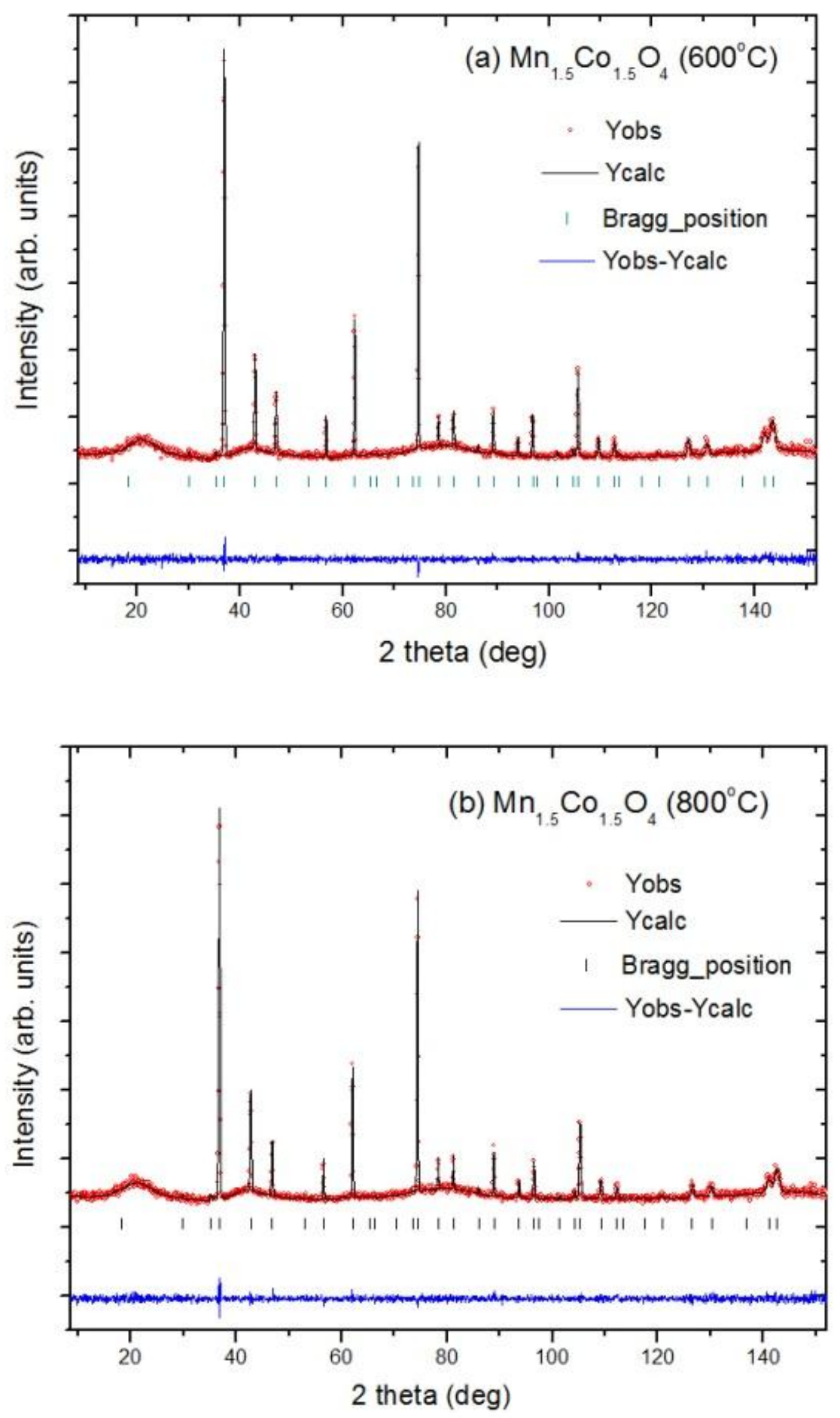

Figure 9. Neutron diffraction patterns of $\mathrm{Mn}_{1.5} \mathrm{Co}_{1.5} \mathrm{O}_{4}$ at (a) $600^{\circ} \mathrm{C}$ and (b) $800^{\circ} \mathrm{C}$, respectively. 
At room temperature, $\mathrm{Mn}_{1.5} \mathrm{CO}_{1.5} \mathrm{O}_{4}$ contains a mixture of cubic and tetragonal phases (Figure 10) as has previously been reported by Yang et al. $[7,10]$. With increasing chromium content, the amount of the tetragonal phases decreases and when $x$ reaches 1 , i.e. $\mathrm{MnCoCrO}_{4}$, only the cubic phase is present. Neutron diffraction spectra for $\mathrm{MnCoCrO}_{4}$ at elevated temperatures are shown in Figure 11 and the resulting crystallographic parameter are summarized in Table 2. The analysis was performed assuming that chromium occupies octahedral sites and indicates that, as for $\mathrm{Mn}_{1.5} \mathrm{Co}_{1.5} \mathrm{O}_{4}$, cobalt prefers the tetrahedral site $\left(0.74 / 0.73 \mathrm{Co}, 0.21 / 0.27 \mathrm{Mn}\right.$ at $\left.600^{\circ} \mathrm{C} / 800^{\circ} \mathrm{C}\right)$ while manganese prefers the octahedral site $\left(0.44 / 0.39 \mathrm{Mn}, 0.14 / 0.11 \mathrm{Co}\right.$ at $\left.600^{\circ} \mathrm{C} / 800^{\circ} \mathrm{C}\right)$. The relative preference of cobalt for the tetrahedral site and manganese for the octahedral site is consistent with previous results [11].

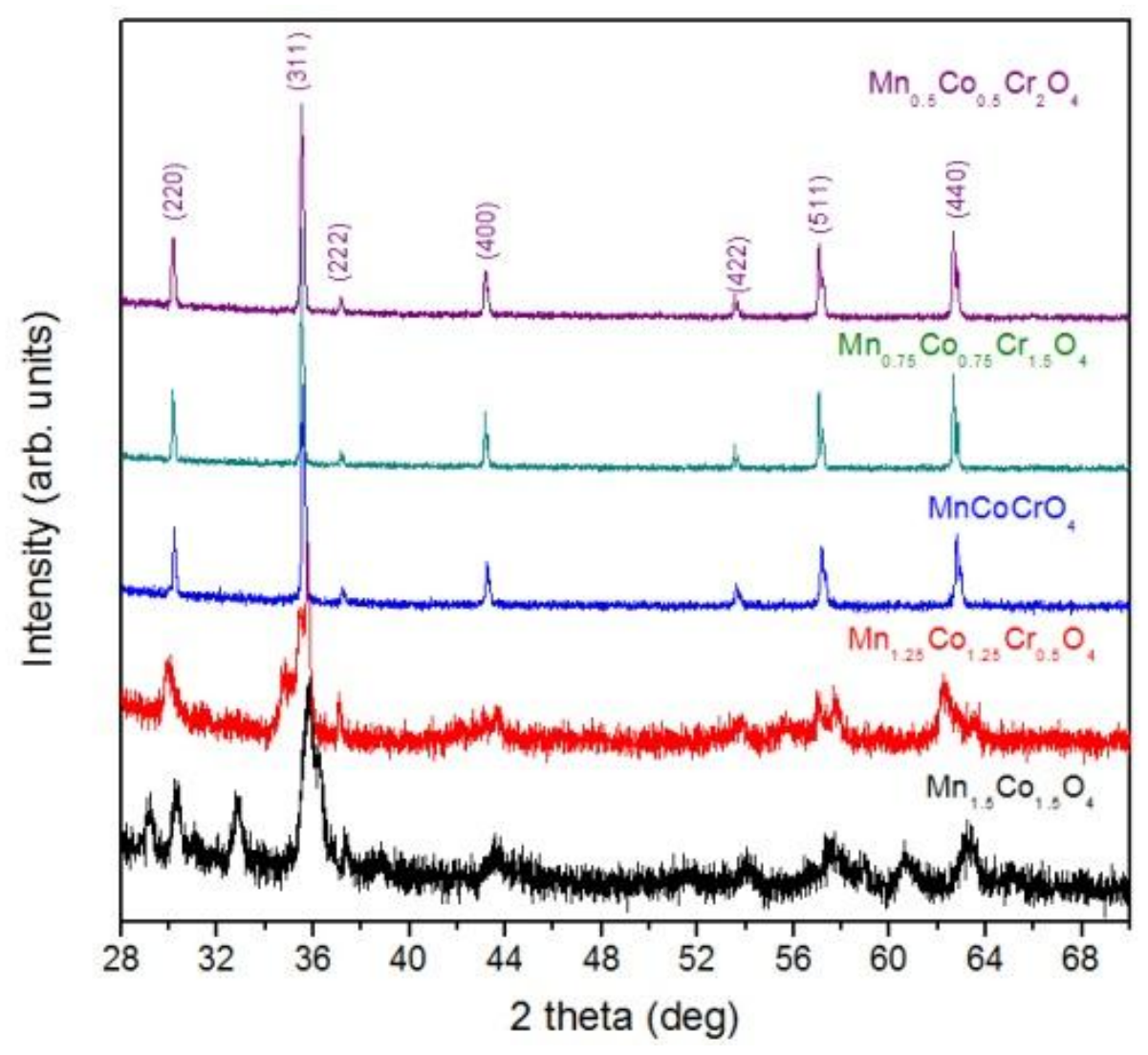

Figure 10. XRD patterns of $\mathrm{Mn}_{1.5-\mathrm{x} / 2} \mathrm{Co}_{1.5-\mathrm{x} / 2} \mathrm{Cr}_{x} \mathrm{O}_{4}(x=0-2)$ spinel oxides at room temperature. 

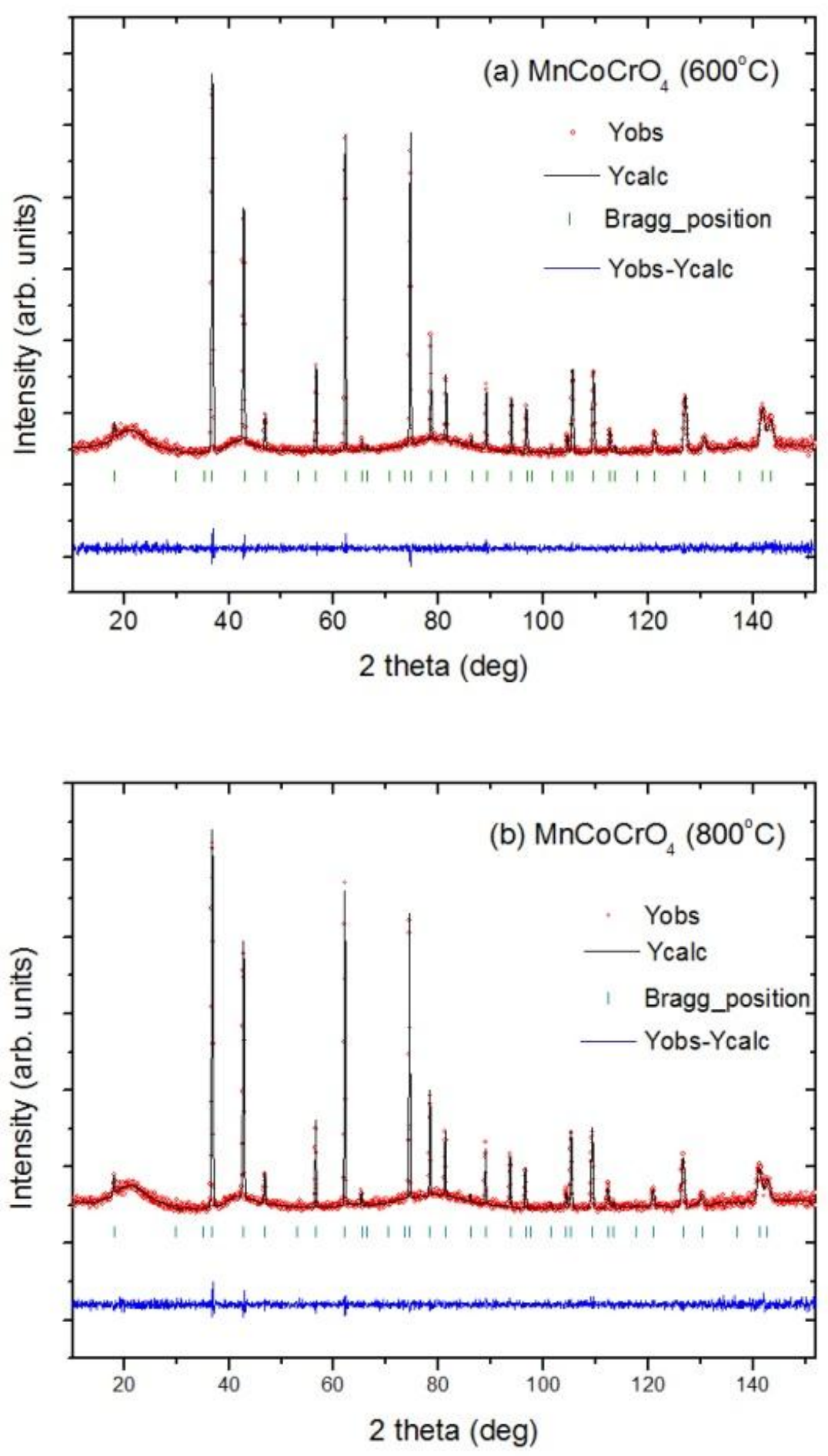

Figure 11. Neutron diffraction patterns of $\mathrm{MnCoCrO}_{4}$ at (a) $600^{\circ} \mathrm{C}$ and (b) $800^{\circ} \mathrm{C}$, respectively. 


\begin{tabular}{|c|c|c|c|}
\hline & $600^{\circ} \mathrm{C}$ & $800^{\circ} \mathrm{C}$ \\
\hline \multicolumn{2}{|c|}{ a $(\AA ̊)$} & $8.413(9)$ & $8.430(1)$ \\
\hline \multicolumn{2}{|c|}{ U oxygen } & $0.2620(0)$ & $0.2620(7)$ \\
\hline \multirow{2}{*}{ Tetrahedral } & {$[\mathrm{Mn}]_{\mathrm{A}}$} & 0.2092 & 0.2712 \\
\hline & {$[\mathrm{Co}]_{A}$} & 0.7382 & 0.7288 \\
\hline \multirow{3}{*}{ Octahedral } & {$[\mathrm{Mn}]_{\mathrm{B}}$} & 0.4408 & 0.3924 \\
\hline & {$[\mathrm{Co}]_{\mathrm{B}}$} & 0.1483 & 0.1076 \\
\hline & {$[\mathrm{Cr}]_{\mathrm{B}}$} & 0.4870 & 0.4892 \\
\hline \multicolumn{2}{|c|}{$\mathrm{R}_{\mathrm{wp}}$} & 4.79 & 4.82 \\
\hline \multicolumn{2}{|c|}{$R_{\exp }$} & 4.27 & 4.27 \\
\hline \multicolumn{2}{|c|}{$\mathrm{R}_{\mathrm{B}}$} & 3.17 & 2.45 \\
\hline
\end{tabular}

\section{Mn:Co $\neq 1: 1$}

Although $\mathrm{Mn}_{1.5} \mathrm{Co}_{1.5} \mathrm{O}_{4}$ is the most widely used manganese-cobalt spinel oxide coating materials other compositions have been used. The effect of the Mn:Co ratio was evaluated using samples with three different compositions: $\mathrm{Mn}_{2} \mathrm{CoO}_{4}, \mathrm{Mn}_{1.5} \mathrm{Co}_{1.5} \mathrm{O}_{4}$ and $\mathrm{MnCo}_{2} \mathrm{O}_{4}$. The surface morphologies of the samples after reaction were similar (not shown). The only exception was that the amount of porosity for the reaction layer formed by vapor phase transport on the composition with the highest cobalt content, $\mathrm{MnCO}_{2} \mathrm{O}_{4}$, was higher. One possible reason for this difference is that this composition is expected to consist of a two-phase mixture of a spinel phase (lower cobalt) and a rocksalt phase (higher cobalt) at $1200^{\circ} \mathrm{C}$. However, this two-phase microstructure did not appear to affect the reaction layer formed in contact with chromia powder. As shown in Table 3, the Co/Mn ratio in this surface layer increased with increasing cobalt content in the $(\mathrm{Mn}, \mathrm{Co})_{3} \mathrm{O}_{4}$ spinel, but the cobalt content in the surface layer was generally higher than that in the original $(\mathrm{Mn}, \mathrm{Co})_{3} \mathrm{O}_{4}$ spinel.

Figure 12 shows the results of a platinum marker experiment for the reaction between $\mathrm{Mn}_{2} \mathrm{CoO}_{4}$ and $\mathrm{Cr}_{2} \mathrm{O}_{3}$ for 144 hours in air at $1000^{\circ} \mathrm{C}$. As with $\mathrm{Mn}_{1.5} \mathrm{Co}_{1.5} \mathrm{O}_{4}$ the platinum marker is located to the left of the dense high-chromium layer indicating that this layer grows to the right (i.e. toward the $\mathrm{Cr}_{2} \mathrm{O}_{3}$ ).

\begin{tabular}{|c|c|c|c|c|c|}
\hline \multicolumn{6}{|c|}{ Table 3. Spinel compositions as determined by EDS. } \\
\hline \multirow{2}{*}{ Initial composition } & \multicolumn{4}{|c|}{ Surface composition after 72 hours at $1200^{\circ} \mathrm{C}$} \\
\cline { 2 - 6 } & \multicolumn{2}{|c|}{ Solid-solid contact } & \multicolumn{2}{c|}{ Vapor-phase transport } \\
\hline Formula & $\mathrm{Co} / \mathrm{Mn}$ & Formula & $\mathrm{Co} / \mathrm{Mn}$ & Formula & $\mathrm{Co} / \mathrm{Mn}$ \\
\hline $\mathrm{Mn}_{2} \mathrm{CoO}_{4}$ & 0.5 & $\mathrm{Mn}_{0.65} \mathrm{Co}_{0.35} \mathrm{Cr}_{2} \mathrm{O}_{4}$ & 0.54 & $\mathrm{Mn}_{1.3} \mathrm{Co}_{0.85} \mathrm{Cr}_{0.85} \mathrm{O}_{4}$ & 0.85 \\
\hline $\mathrm{Mn}_{1.5} \mathrm{Co}_{1.5} \mathrm{O}_{4}$ & 1.0 & $\mathrm{Mn}_{0.40} \mathrm{Co}_{0.60} \mathrm{Cr}_{2} \mathrm{O}_{4}$ & 1.5 & $\mathrm{Mn}_{0.8 .} \mathrm{Co}_{1.3} \mathrm{Cr}_{0.9} \mathrm{O}_{4}$ & 1.6 \\
\hline $\mathrm{MnCo}_{2} \mathrm{O}_{4}$ & 2.0 & $\mathrm{Mn}_{0.25} \mathrm{Co}_{0.75} \mathrm{Cr}_{2} \mathrm{O}_{4}$ & 3.0 & $\mathrm{Mn}_{1.0} \mathrm{Co}_{1.45} \mathrm{Cr}_{0.55} \mathrm{O}_{4}$ & 1.45 \\
\hline
\end{tabular}



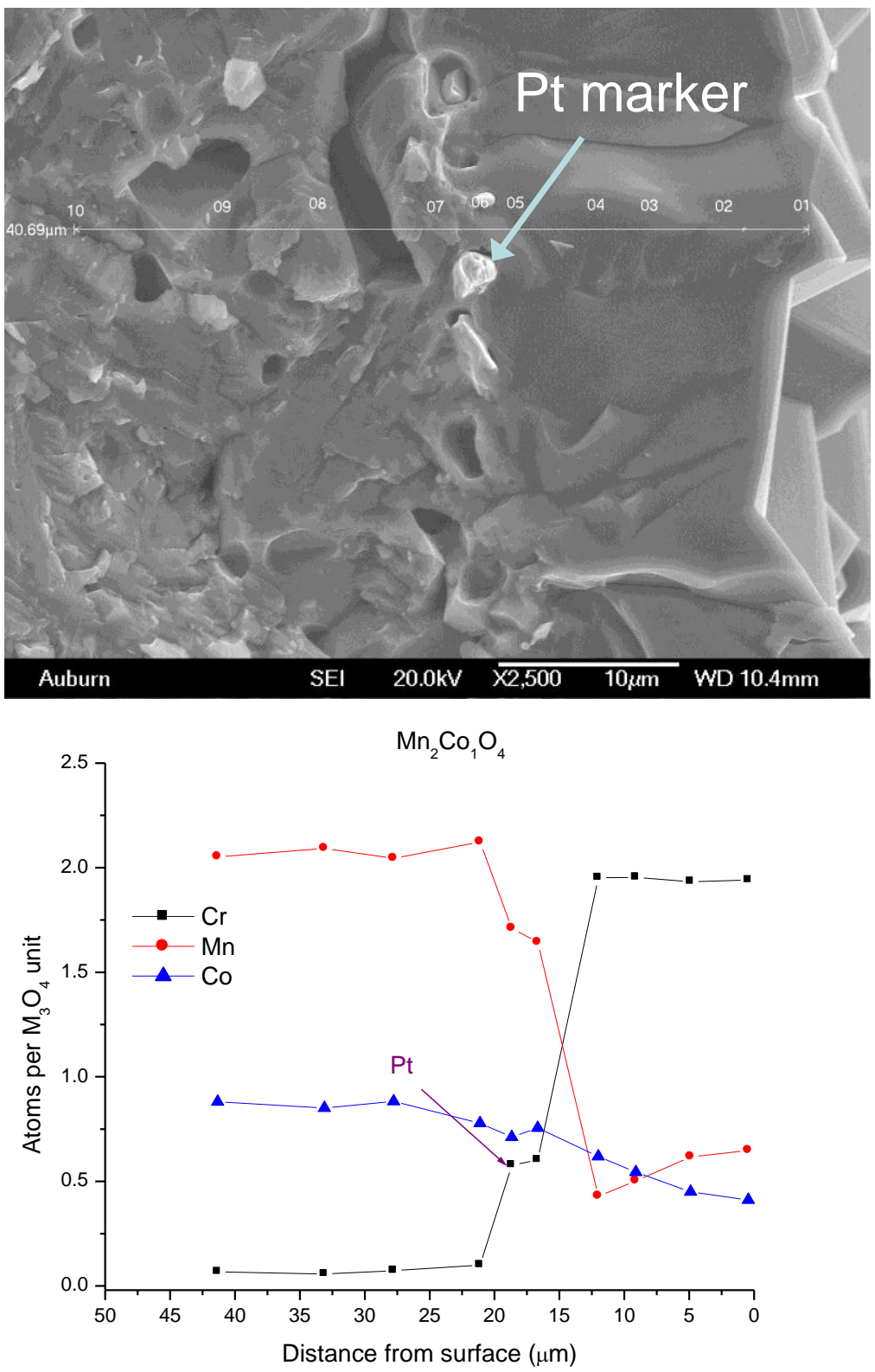

Figure 12. Cross section of $\mathrm{Mn}_{2} \mathrm{CoO}_{4}$ prepared by sintering after reaction with $\mathrm{Cr}_{2} \mathrm{O}_{3}$ in air at $1000^{\circ} \mathrm{C}$ for 144 hours. 


\section{Electrical Conductivity}

The conductivities of the coating materials were determined using 4-point dc conductivity measurements. The measured conductivities of $(\mathrm{Mn}, \mathrm{Co})_{3} \mathrm{O}_{4}$, shown in Figure 13, are in agreement with results from in the literature $[7,12,13]$. The box indicated by the broken lines will be used in subsequent plots to compare $(\mathrm{Mn}, \mathrm{Co})_{3} \mathrm{O}_{4}$ with other materials. Similarly, it is useful to compare the conductivities with $\mathrm{Cr}_{2} \mathrm{O}_{3}$, which will be present at the alloy-coating interface. Figure 14 [14-18] shows that there is considerable variation in the measured conductivities of $\mathrm{Cr}_{2} \mathrm{O}_{3}$, which is due to the difficulty in preparing dense $\mathrm{Cr}_{2} \mathrm{O}_{3}$ samples and the sensitivity of the conductivity to small amounts of impurity elements. The addition of chromium to $(\mathrm{Mn}, \mathrm{Co})_{3} \mathrm{O}_{4}$ leads to a decrease in conductivity as shown in Figure 15 . The activation energy and the conductivities at $800^{\circ} \mathrm{C}$ of $(\mathrm{Mn}, \mathrm{Co})_{3-x} \mathrm{Cr}_{x} \mathrm{O}_{4}$ are shown in Figure 16 . The conductivities of the high chromium spinel phase and chromia are orders of magnitude lower than the coating materials, so even if the reaction layers are thin, they likely would dominate the overall resistance.

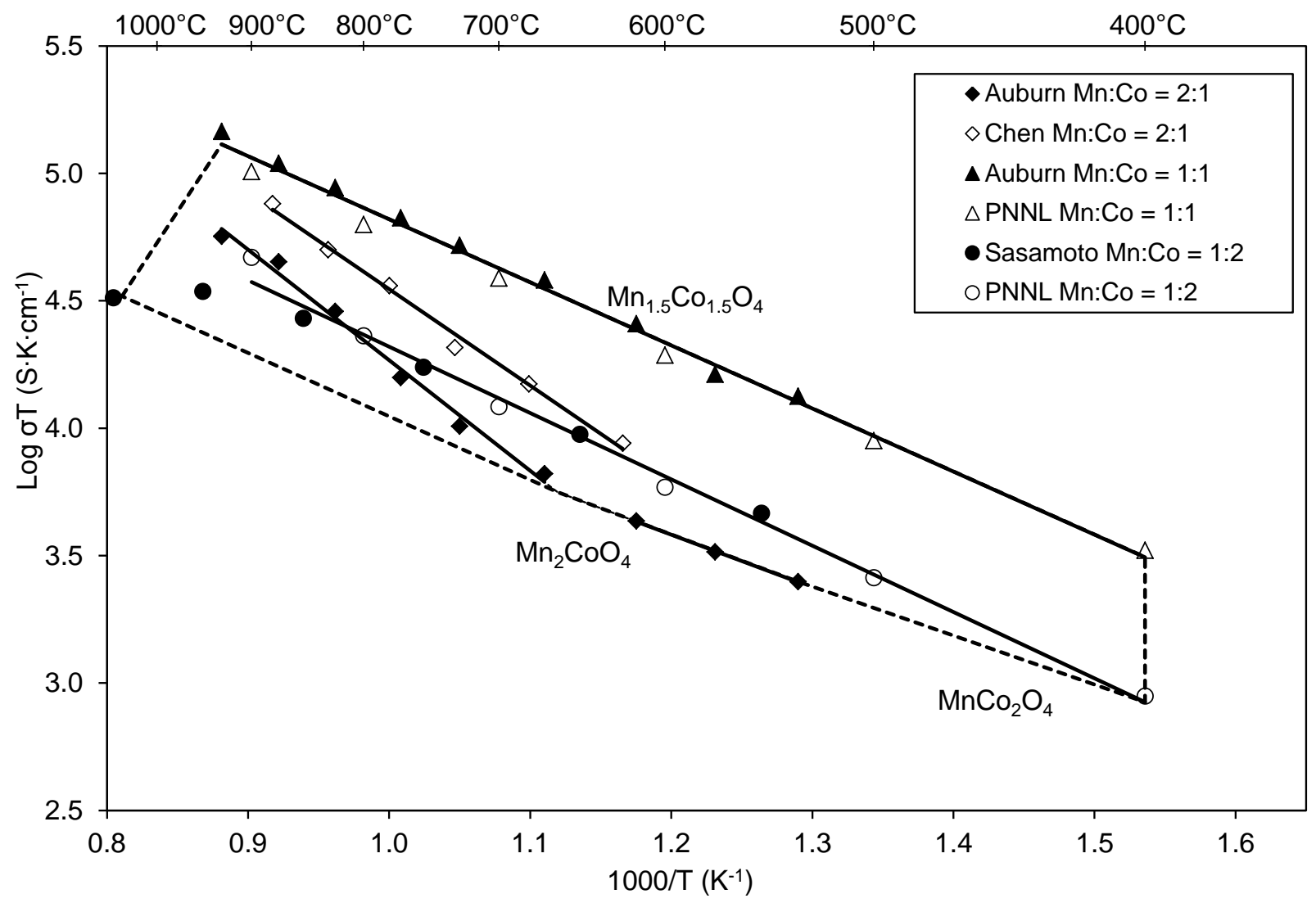

Figure 13 . Conductivity of $(\mathrm{Mn}, \mathrm{Co})_{3} \mathrm{O}_{4}[\mathrm{7}, 12,13]$ 


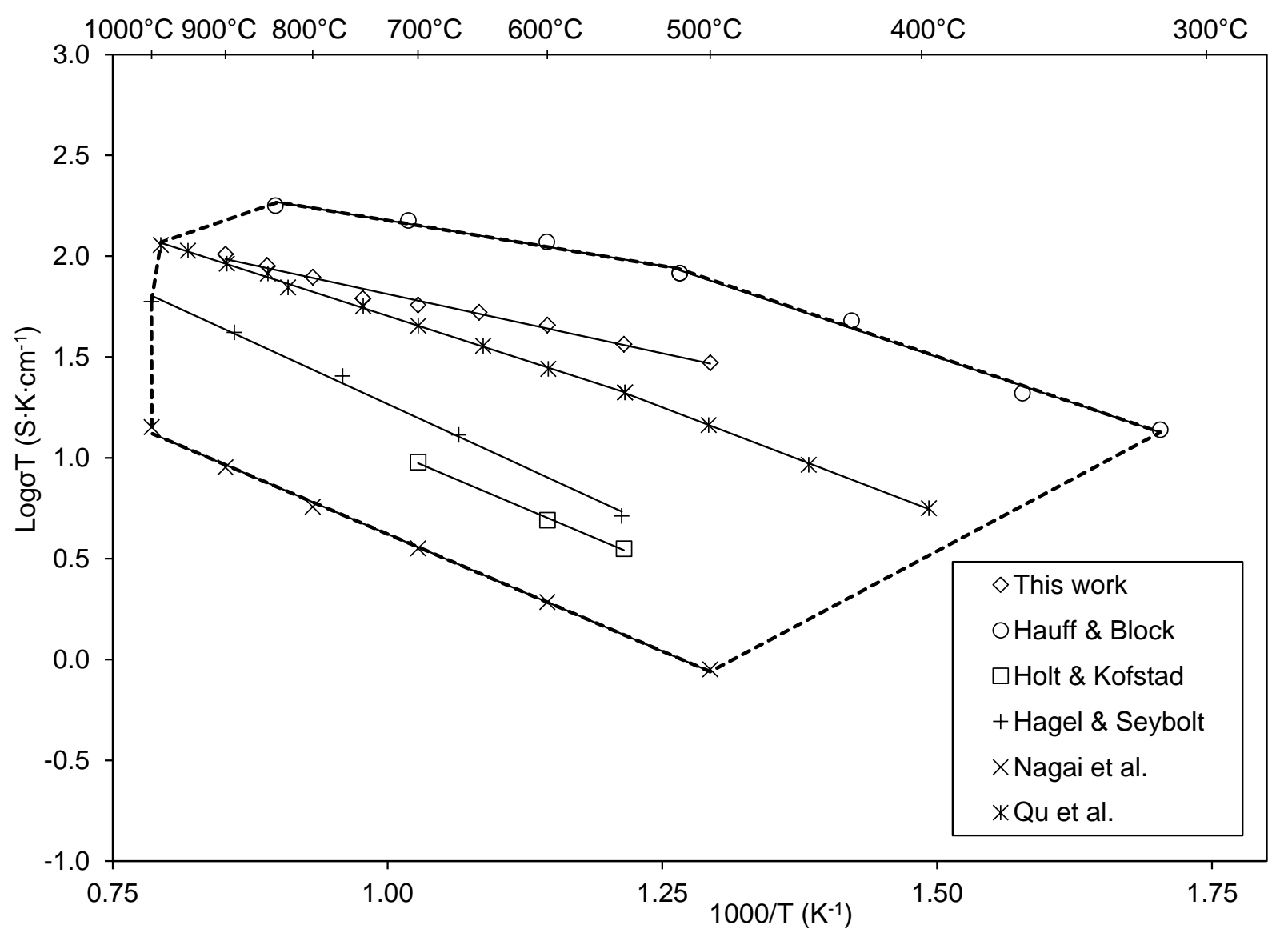

Figure 14. Conductivity of $\mathrm{Cr}_{2} \mathrm{O}_{3}$ [14-18].

As shown above, the Mn:Co ratio in the reaction layer can be different from that in the coating material as a result of site preferences. Figure 17 shows that the electrical conductivities of $(\mathrm{Mn}, \mathrm{Co})_{2} \mathrm{CrO}_{4}$ and $(\mathrm{Mn}, \mathrm{Co})_{1.5} \mathrm{Cr}_{1.5} \mathrm{O}_{4}$ increase with increasing cobalt composition. Although cobalt may be beneficial to the coating performance, it is relatively expensive, so lower cost replacements for cobalt are desirable. 


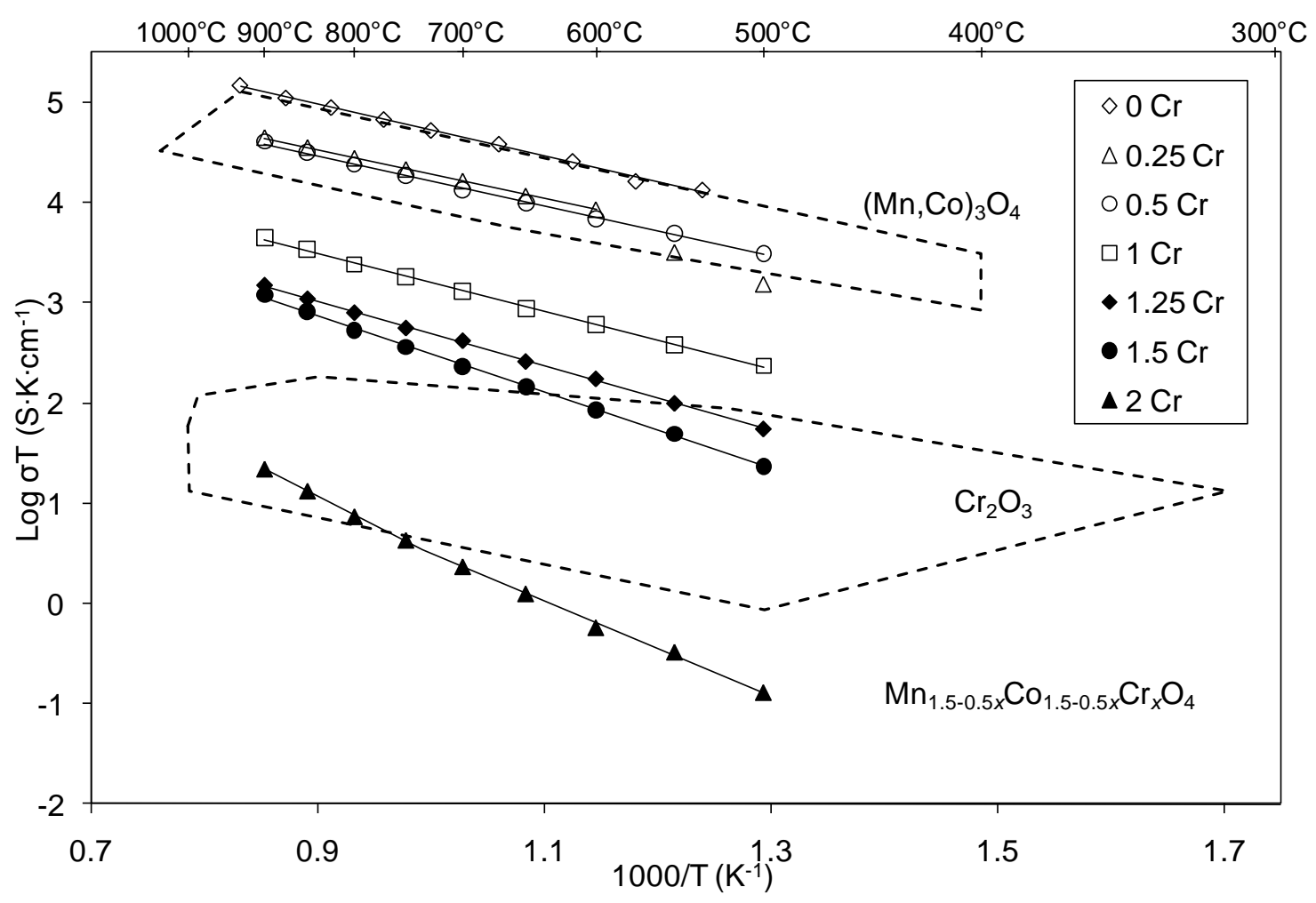

Figure 15. Conductivity of $\mathrm{Mn}_{1.5-0.5 x} \mathrm{Co}_{1.5-0.5 x} \mathrm{Cr}_{x} \mathrm{O}_{4}$ in air.

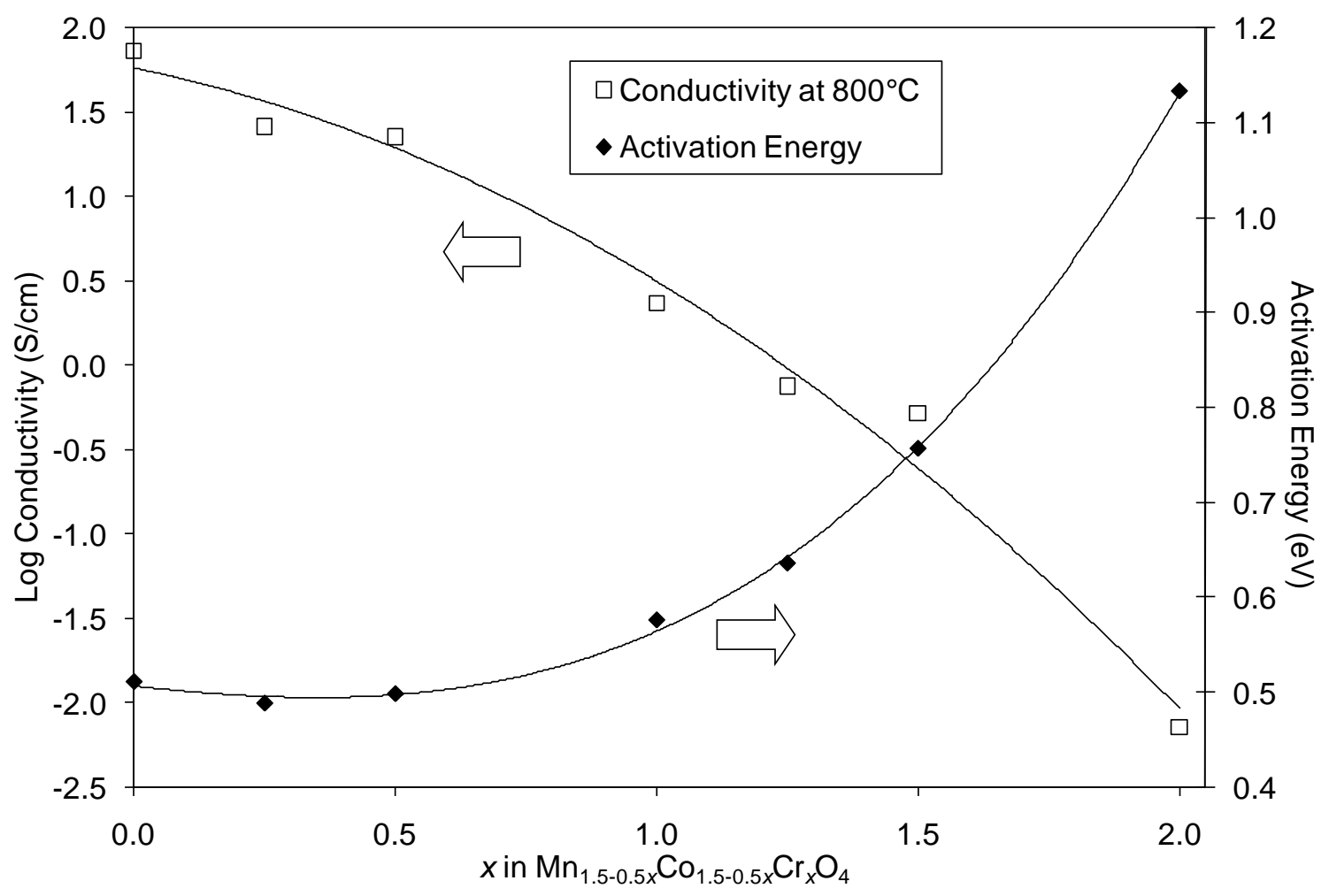

Figure 16. Conductivity and activation energy of $\mathrm{Mn}_{1.5-0.5 x} \mathrm{Co}_{1.5-0.5 x} \mathrm{Cr}_{x} \mathrm{O}_{4}$ in air. 

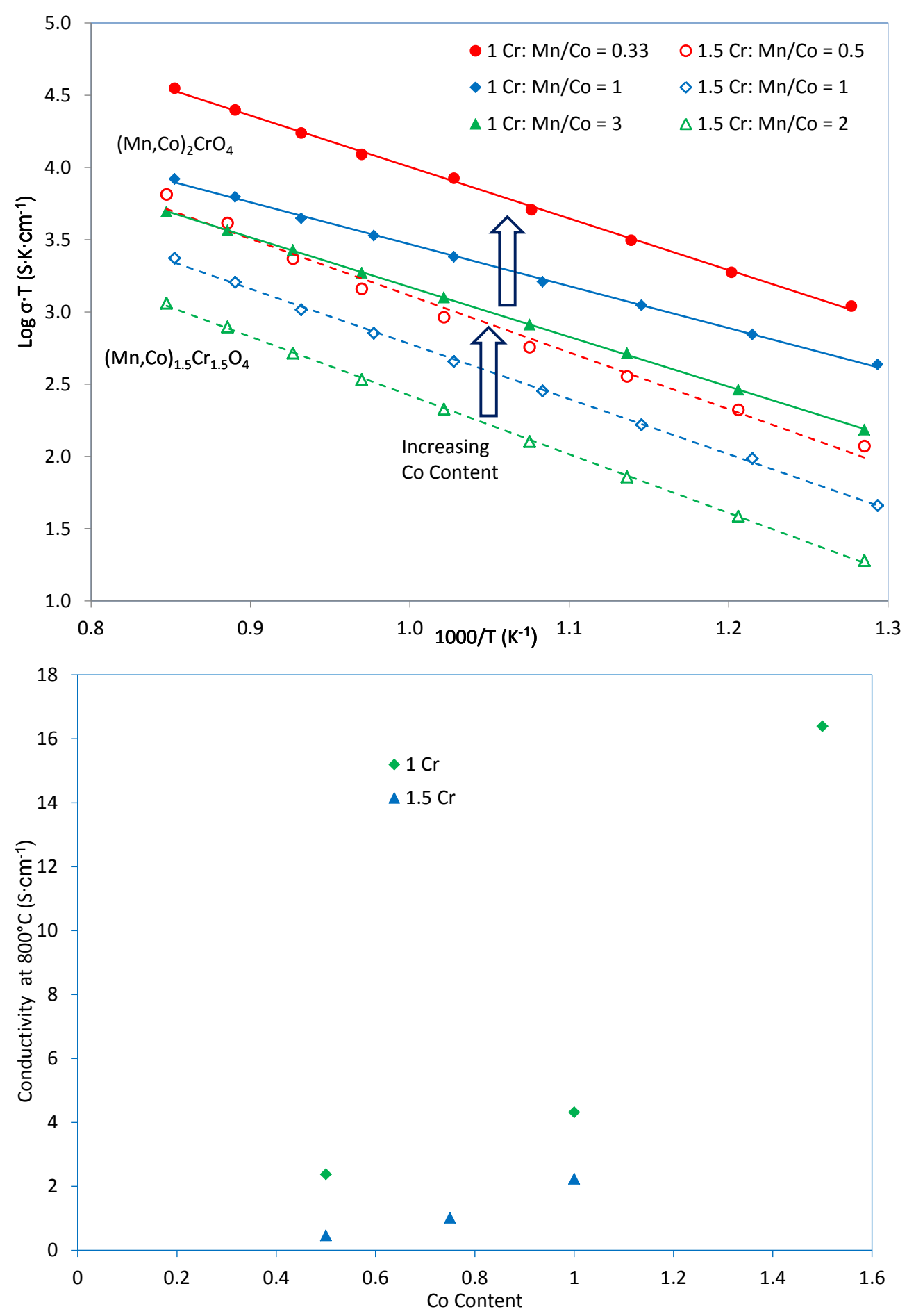

Figure 17. Conductivity of $(\mathrm{Mn}, \mathrm{Co}){ }_{2} \mathrm{CrO}_{4}$ and $(\mathrm{Mn}, \mathrm{Co})_{1.5} \mathrm{Cr}_{1.5} \mathrm{O}_{4}$ in air - Arrhenius plot (a) and conductivity at $800^{\circ} \mathrm{C}(\mathrm{b})$. 
One of the challenges in characterizing chromium-containing oxides is sample preparation. Highchromium-containing compositions do not sinter well, because densification is inhibited by the oxidation of chromium oxide to $\mathrm{Cr}^{6+}$-containing vapors. One approach to improving densification is to sinter at lower oxygen partial pressures were the vapor pressures of these species are low. This approach was investigated in this project by sintering in the presence of carbon to obtain a reducing atmosphere. Comparison of Figures 18 and 19 shows that a reducing atmosphere improved the densification of $\mathrm{Cr}_{2} \mathrm{O}_{3}$ and Figure 20 shows densification in a high-chromium containing spinel $\left(\mathrm{Mn}_{0.75} \mathrm{Co}_{0.75} \mathrm{Cr}_{1.5} \mathrm{O}_{4}\right)$. However, carbide phases were present and samples with uniform sintering were not obtained.

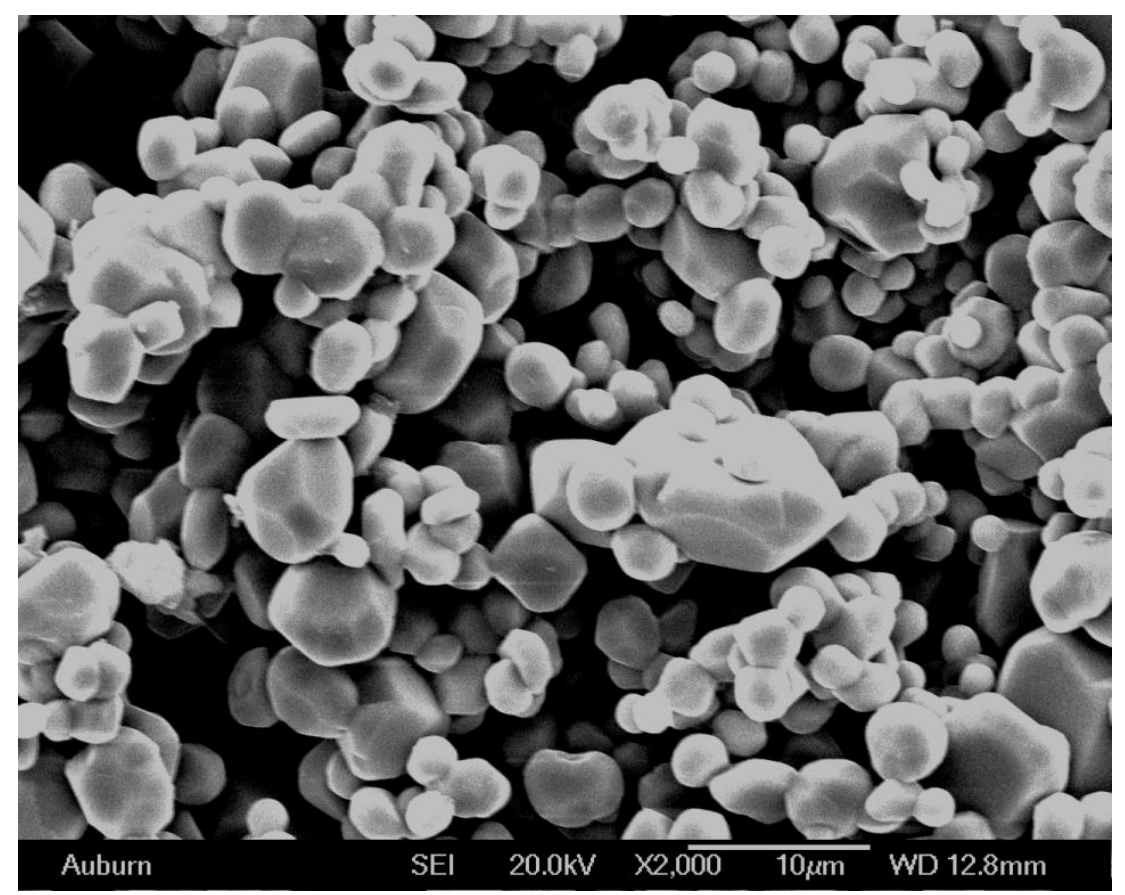

Figure 18. Microstructure of chromium oxide sintered at $1500^{\circ} \mathrm{C}$ for $3 \mathrm{~h}$ in air showing porosity. 


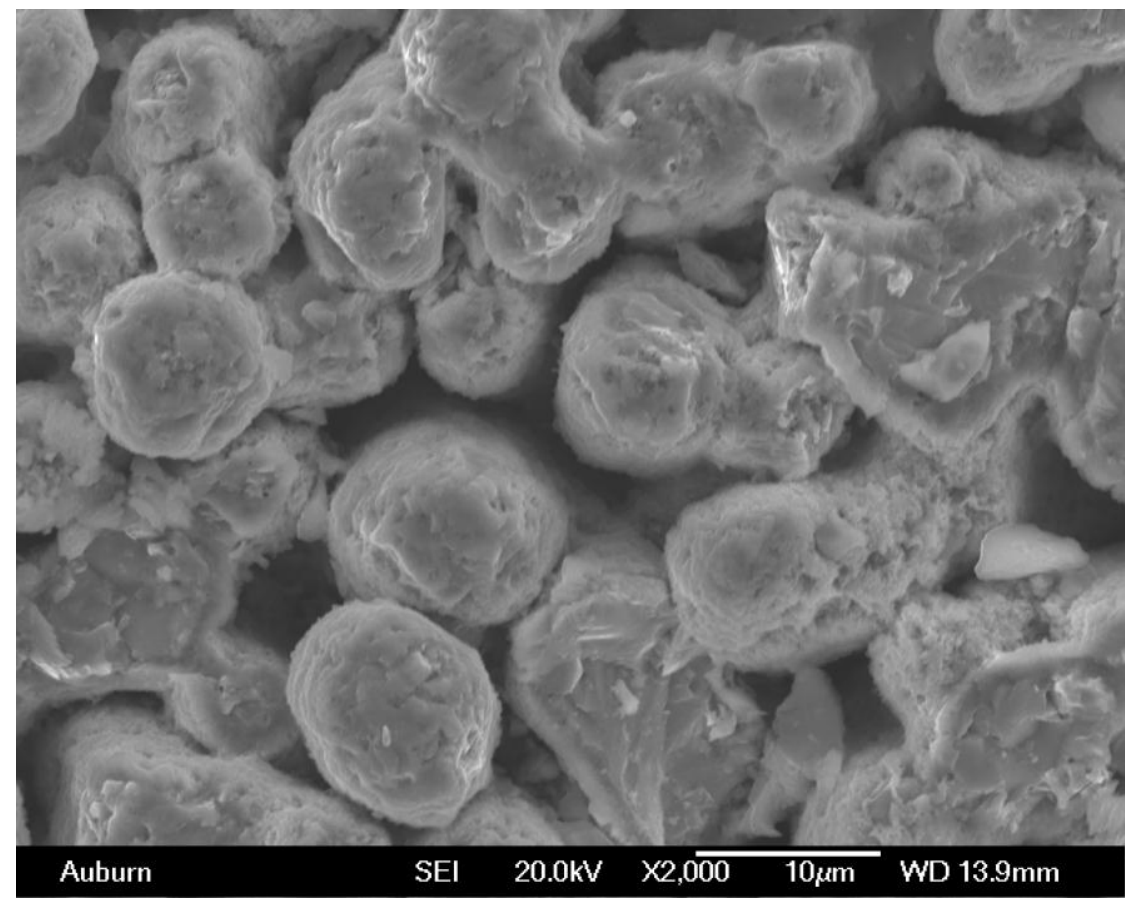

Figure 19. Densification and grain growth in $\mathrm{Cr}_{2} \mathrm{O}_{3}$ sintered at $1500^{\circ} \mathrm{C}$ for $3 \mathrm{~h}$ in reducing atmosphere.

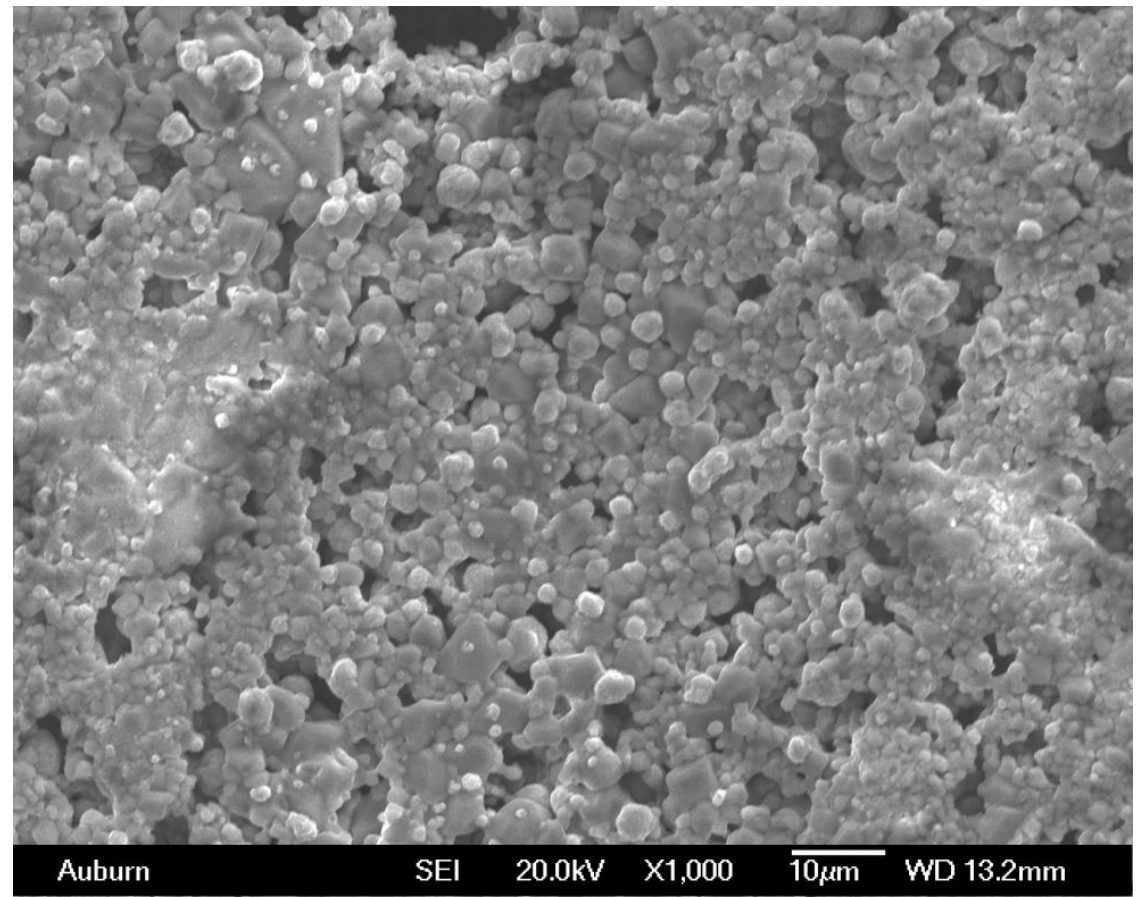

Figure 20. $\left(\mathrm{Mn}_{0.75} \mathrm{Co}_{0.75} \mathrm{Cr}_{1.5} \mathrm{O}_{4}\right)$ sintered at $1300^{\circ} \mathrm{C}$ for $4 \mathrm{~h}$ in reducing atmosphere showing initiation of sintering and grain growth. 


\section{Thermal Expansion}

Thermal expansion compatibility is required in SOFC applications to reduce the thermal stress and avoid component spallation for good long-term performance. The coefficients of thermal expansion (CTE) were measured for several spinel compositions and are listed in Table 4. The trend for the addition of chromium, iron and titanium to $\mathrm{Mn}_{1.5} \mathrm{Co}_{1.5} \mathrm{O}_{4}$ are shown in Figure 21. All three elements lead to a decrease in the CTE, but the effect is stronger for iron and titanium than it is for chromium. However, increasing the cobalt content increases the CTE, so the addition of iron or titanium with an increase in the Co:Mn ratio offsets the effect iron and titanium, such that the CTEs of $\mathrm{MnCO}_{1.66} \mathrm{Fe}_{0.34} \mathrm{O}_{4}$ and $\mathrm{MnCo}_{1.66} \mathrm{Ti}_{0.34} \mathrm{O}_{4}$ are higher than that of $\mathrm{Mn}_{1.5} \mathrm{Co}_{1.5} \mathrm{O}_{4}$ (but lower than that $\mathrm{MnCo}_{2} \mathrm{O}_{4}$ ). For comparison, the CTE for yttria stabilized zirconia and ferritic stainless steels are 9-10 $\times 10^{-6 \circ} \mathrm{C}^{-1}[19-21]$ and $10-12 \times 10^{-6 \circ} \mathrm{C}^{-1}[22]$, respectively. For low dopant contents, the CTEs are similar to other SOFC components, but the CTEs of high-chromium spinel compositions are lower, which could lead to stresses during thermal cycling.

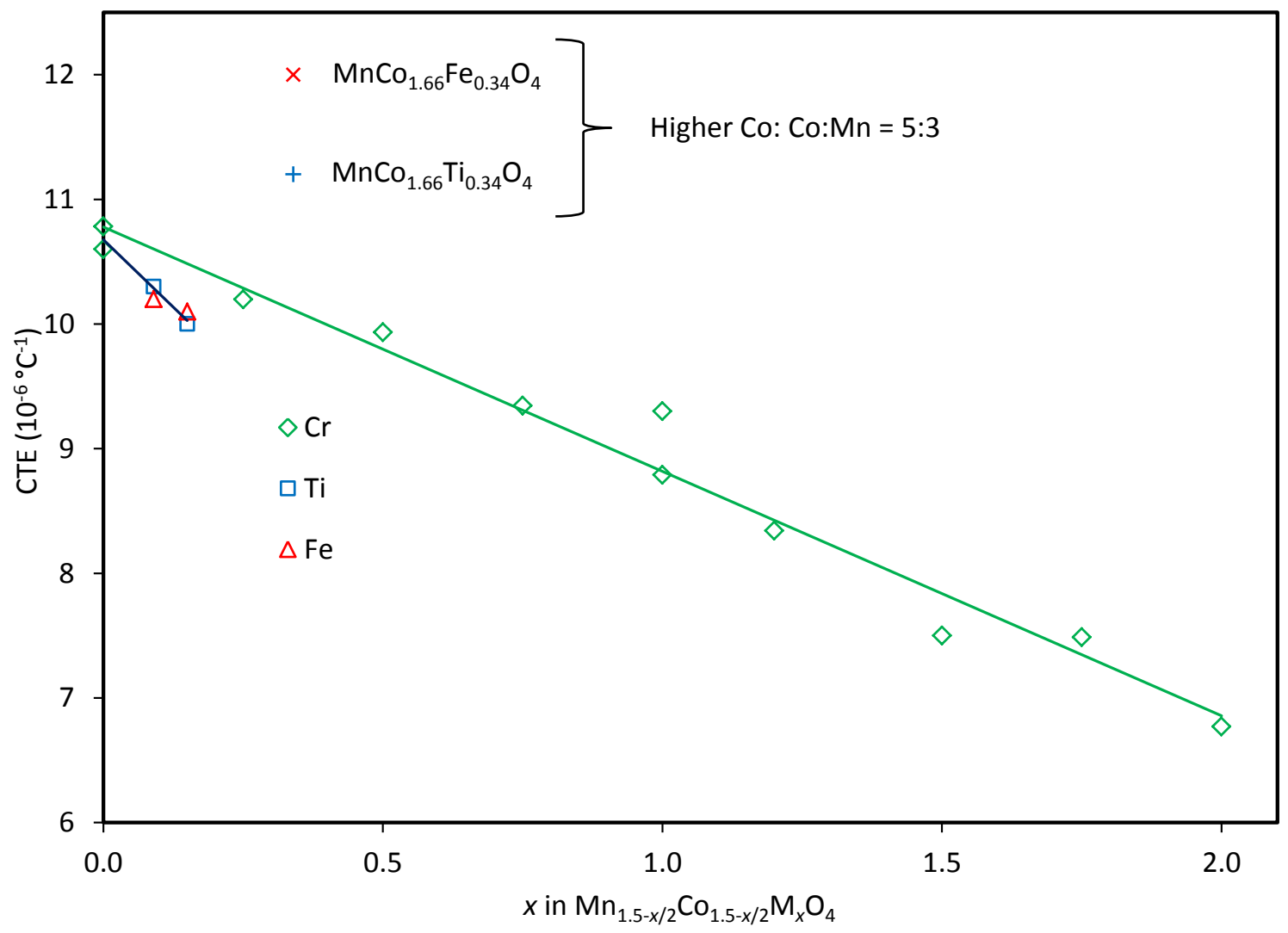

Figure 21. CTE of $(\mathrm{Mn}, \mathrm{Co})_{3-\mathrm{x}} \mathrm{M}_{\mathrm{x}} \mathrm{O}_{4}$ spinel oxides from 20 to $1000^{\circ} \mathrm{C}$ in air. 
Table 4. Coefficient of Thermal Expansion (CTE)

\begin{tabular}{|c|c|c|c|c|c|}
\hline \multicolumn{5}{|c|}{ Atoms per Formula Unit $\left(\mathrm{M}_{3} \mathrm{O}_{4}\right)$} & \multirow{2}{*}{$\begin{array}{c}\text { CTE } \\
10^{-60} \mathrm{C}^{-6}\end{array}$} \\
\hline $\mathrm{Mn}$ & Co & $\mathrm{Fe}$ & $\mathrm{Ti}$ & $\mathrm{Cr}$ & \\
\hline 2 & 1 & & & & 6.9 \\
\hline 1.5 & 1.5 & & & & 10.7 \\
\hline 1 & 2 & & & & 14.1 \\
\hline 1.455 & 1.455 & 0.09 & & & 10.2 \\
\hline 1.425 & 1.425 & 0.15 & & & 10.1 \\
\hline 1 & 1.66 & 0.34 & & & 12.0 \\
\hline 1 & 1.9 & 0.1 & & & 12.3 \\
\hline 1.455 & 1.455 & & 0.09 & & 10.3 \\
\hline 1.425 & 1.425 & & 0.15 & & 10.0 \\
\hline 1 & 1.66 & & 0.34 & & 11.2 \\
\hline 1 & 1.9 & & 0.1 & & 13.5 \\
\hline 1.375 & 1.375 & & & 0.25 & 10.2 \\
\hline 1.25 & 1.25 & & & 0.5 & 9.9 \\
\hline 1.125 & 1.125 & & & 0.75 & 9.3 \\
\hline 1 & 1 & & & 1 & 9.0 \\
\hline 0.9 & 0.9 & & & 1.2 & 8.3 \\
\hline 0.75 & 0.75 & & & 1.5 & 7.5 \\
\hline 0.625 & 0.625 & & & 1.75 & 7.5 \\
\hline 0.5 & 0.5 & & & 2 & 6.8 \\
\hline 0.4 & 0.6 & & & 2 & 7.1 \\
\hline
\end{tabular}

\section{$\operatorname{Doped}(\mathrm{Mn}, \mathrm{Co})_{3} \mathrm{O}_{4}$}

The performance of a coating material depends on the reaction with chromia and the transport properties, both of which can be affected by the coating composition, so doping of the coating was investigated. 
The first additions evaluated were with titanium, iron and yttrium. The chromium composition gradients as determined by energy dispersive x-ray spectroscopy (EDS) at the cross-section between $\mathrm{Cr}_{2} \mathrm{O}_{3}$ and doped/undoped $(\mathrm{Mn}, \mathrm{Co})_{3} \mathrm{O}_{4}$ after 336 hours at $800^{\circ} \mathrm{C}$ are shown in Figure 22 . The thickness of the reaction layer (i.e. $\left.(\mathrm{Mn}, \mathrm{Co}) \mathrm{Cr}_{2} \mathrm{O}_{4}\right)$ is decreased for all dopants, particularly for the sample with $11 \% \mathrm{Ti}$ and the higher Co content (i.e. $\mathrm{MnCo}_{1.66} \mathrm{Ti}_{0.34} \mathrm{O}_{4}$ ). The chromium concentration gradient in the reaction layer for this composition and an analogous iron doped composition (i.e. $\mathrm{MnCo}_{1.66} \mathrm{Fe}_{0.34} \mathrm{O}_{4}$ ) after reaction at $900^{\circ} \mathrm{C}$ for 144 hours are shown in Figure 23. The reaction layer thickness for the iron-doped composition is slightly thinner, but its coefficient of thermal expansion (CTE) is higher than that of the titanium-doped composition. Figure 24 shows that the conductivity of the iron-doped composition is higher than that of the titanium-doped composition, although the conductivity of the titanium-doped composition is still relatively good (i.e. slightly higher than $\mathrm{MnCo}_{2} \mathrm{O}_{4}$ ). Both dopants are beneficial, but which of the two provides the best performance will depend on the relative importance of electrical resistance and the thermal stresses from the CTE mismatch.

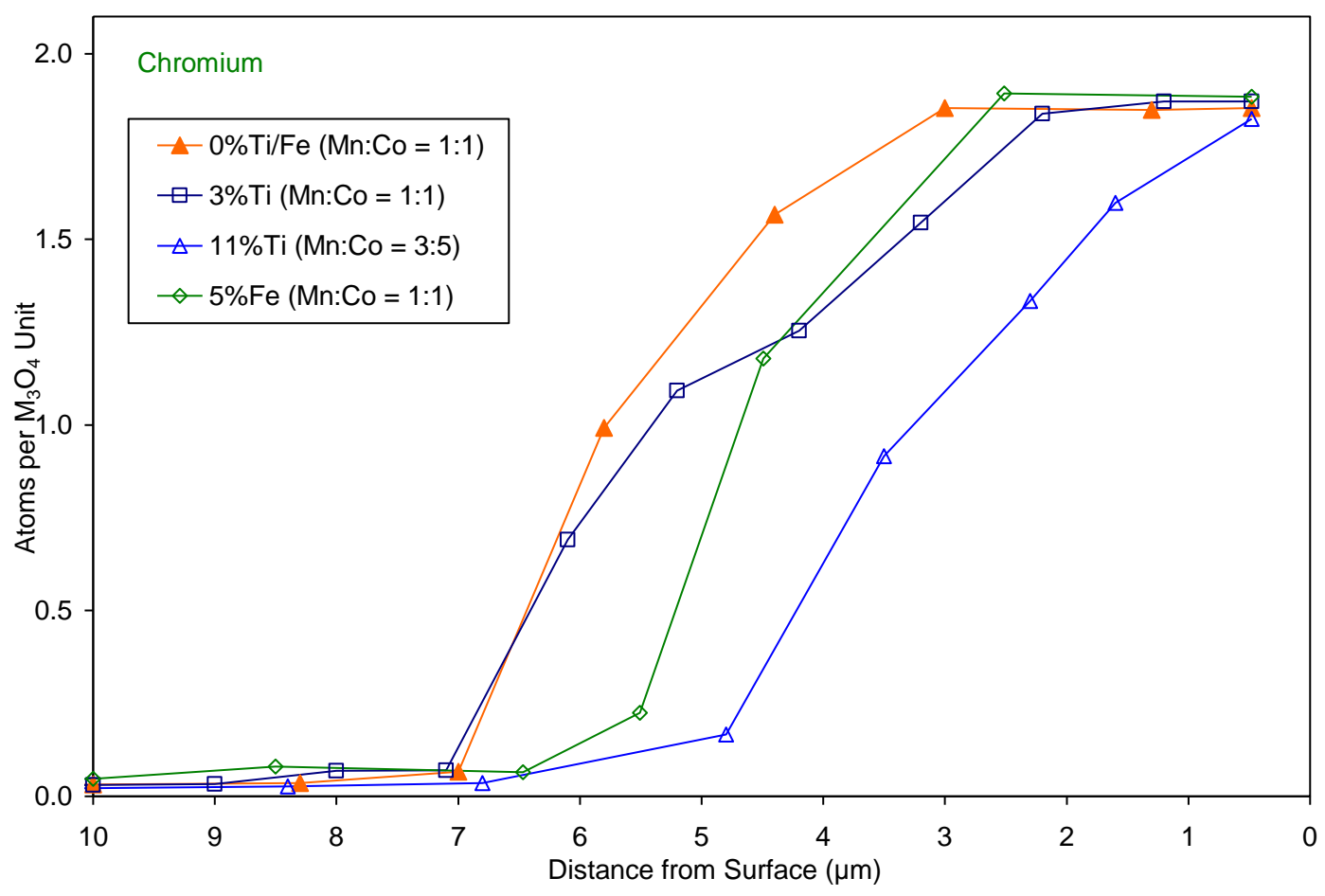

Figure 22. Chromium composition through cross-section between $\mathrm{Cr}_{2} \mathrm{O}_{3}$ and doped (Ti/Fe) or undoped $(\mathrm{Mn}, \mathrm{Co})_{3} \mathrm{O}_{4}$ after 336 hours at $800^{\circ} \mathrm{C}$. 


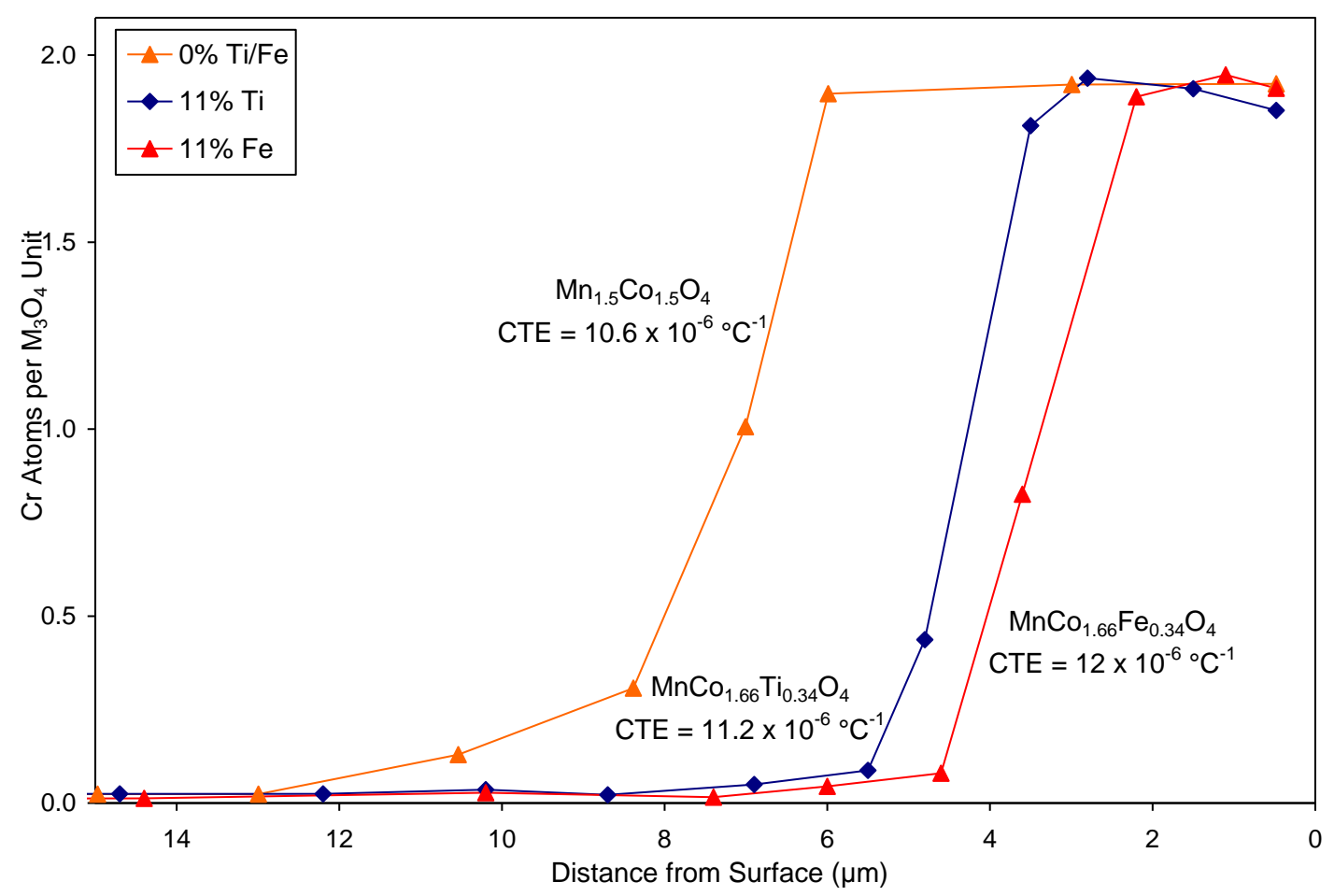

Figure 23. Chromium composition through cross-section between $\mathrm{Cr}_{2} \mathrm{O}_{3}$ and doped $(\mathrm{Ti} / \mathrm{Fe})$ or undoped $(\mathrm{Mn}, \mathrm{Co})_{3} \mathrm{O}_{4}$ after 144 hours at $900^{\circ} \mathrm{C}$.

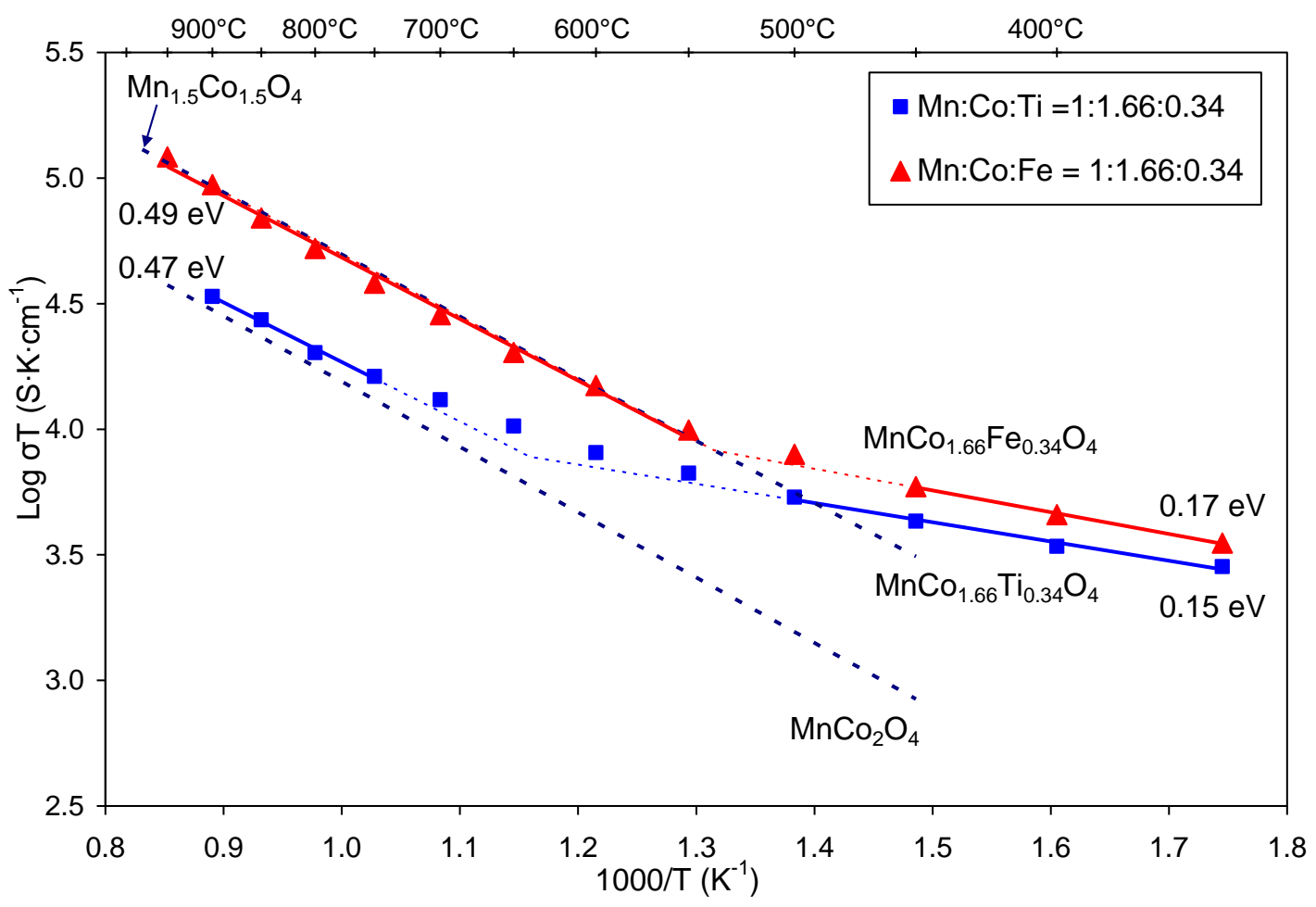

Figure 24. Effect of iron and titanium on the conductivity of $(\mathrm{Mn}, \mathrm{Co})_{3} \mathrm{O}_{4}$ in air. 
Similar behavior is observed at $1000^{\circ} \mathrm{C}$ as shown for $\mathrm{Fe} / \mathrm{Y} / \mathrm{Ti}$-doped or undoped $(\mathrm{Mn}, \mathrm{Co})_{3} \mathrm{O}_{4}$ and $\mathrm{Cr}_{2} \mathrm{O}_{3}$ after 72 hours at $1000^{\circ} \mathrm{C}$ in Figure 25 . In Figure $25 \mathrm{a}$, the distance is referenced to the surface of the spinel pellet after removal of any remaining $\mathrm{Cr}_{2} \mathrm{O}_{3}$, which is useful for comparing the thickness of the high-chromium reaction layer. The results in Figure 25a are replotted in Figure 25b with the distances referenced to the original interface between the spinel and $\mathrm{Cr}_{2} \mathrm{O}_{3}$. Referencing to the original interface facilitates comparison of the concentration gradients. Figure $25 \mathrm{~b}$ shows that the $\mathrm{Cr}$ concentration gradient in the reaction layer in contact with the spinel phase is steeper when the spinel phase is doped. Figure 26 shows that the $\mathrm{Mn}$ and Co gradients are similar for the different compositions. In addition the $\mathrm{Mn} / \mathrm{Co}$ ratio at the interface is similar for all compositions and is higher than the $\mathrm{Mn} / \mathrm{Co}$ ratio in the original spinel. This tendency is consistent with the site preference tendencies discussed above. Specifically, $\mathrm{Cr}$ has the strongest preference for the octahedral site followed by $\mathrm{Mn}$ and then Co. Thus, as $\mathrm{Cr}$ is introduced into the spinel structure $\mathrm{Mn}$ and/or Co are displaced from the octahedral site and must be reduced to a $2+$ valence, since $\mathrm{Cr}$ will likely be $3+$ or higher. Figure 27 shows the concentrations of the dopants after the high-temperatures exposures (the chromium concentrations from Figure $25 \mathrm{~b}$ are shown for reference). Although, as shown in Figure 25a, the dopants decrease the thickness of the high-chromium reaction layer, the dopants are not present in this phase.

As an estimate of the growth rate of the reaction layer, an effective diffusion coefficient was calculated from the measurements of the reaction layer thickness $(x)$ based on the EDS concentration gradient at various times $(t)$. The effective diffusion coefficient is estimated to be $x^{2} / t$ assuming diffusion-limited growth (i.e. constant $x / \sqrt{D t}$ ) and is shown in Figure 28. Although the number of data points is not sufficient to calculate precise activation energies there appears to be a change in the activation energy which appears to correspond with the change in the maximum chromium content in the spinel phase mentioned above (i.e. two $\mathrm{Cr}$ per formula unit at high temperature, but lower at low temperature). 

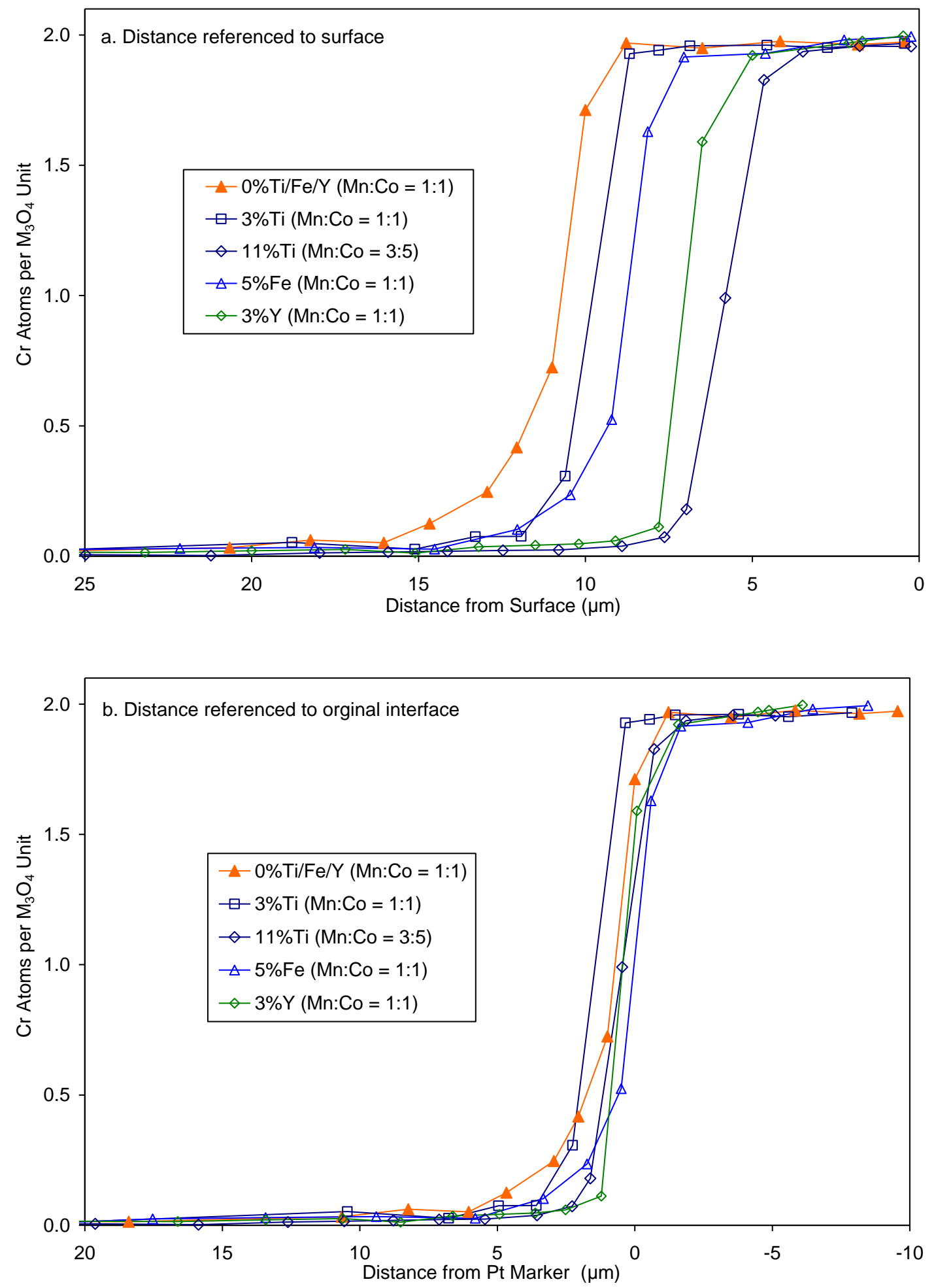

Figure 25. Chromium concentration gradient in $(\mathrm{Mn}, \mathrm{Co}, M)_{3} \mathrm{O}_{4}(M=\mathrm{Ti}, \mathrm{Fe}, \mathrm{Y})$ after being in contact with $\mathrm{Cr}_{2} \mathrm{O}_{3}$ for 72 hours at $1000^{\circ} \mathrm{C}$. a. Distance referenced to surface. b. Distance referenced to original interface. 

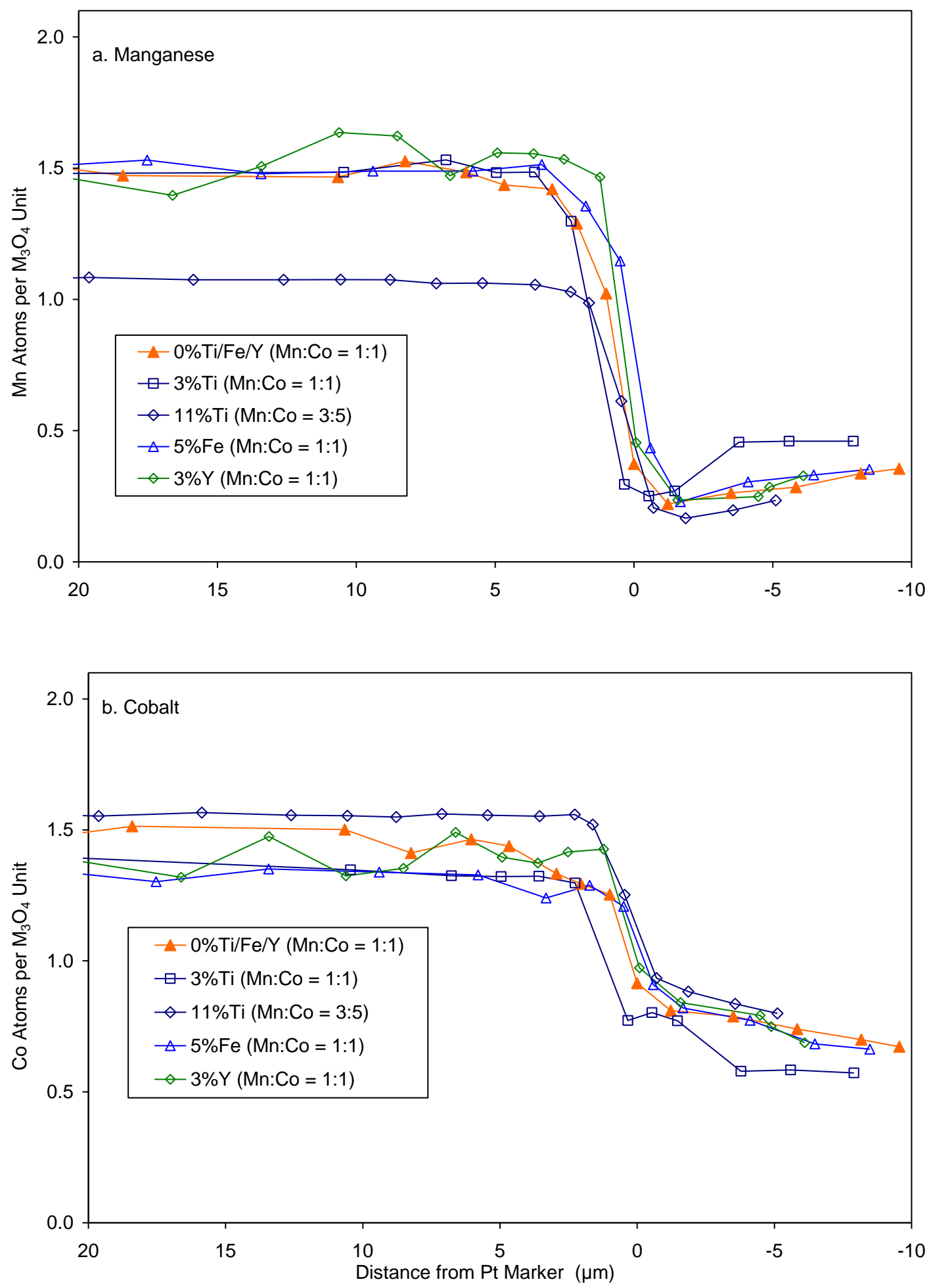

Figure 26. Manganese (a) and cobalt (b) concentration gradients in $(\mathrm{Mn}, \mathrm{Co}, M)_{3} \mathrm{O}_{4}(\mathrm{M}=\mathrm{Ti}, \mathrm{Fe}, \mathrm{Y})$ after being in contact with $\mathrm{Cr}_{2} \mathrm{O}_{3}$ for 72 hours at $1000^{\circ} \mathrm{C}$. 

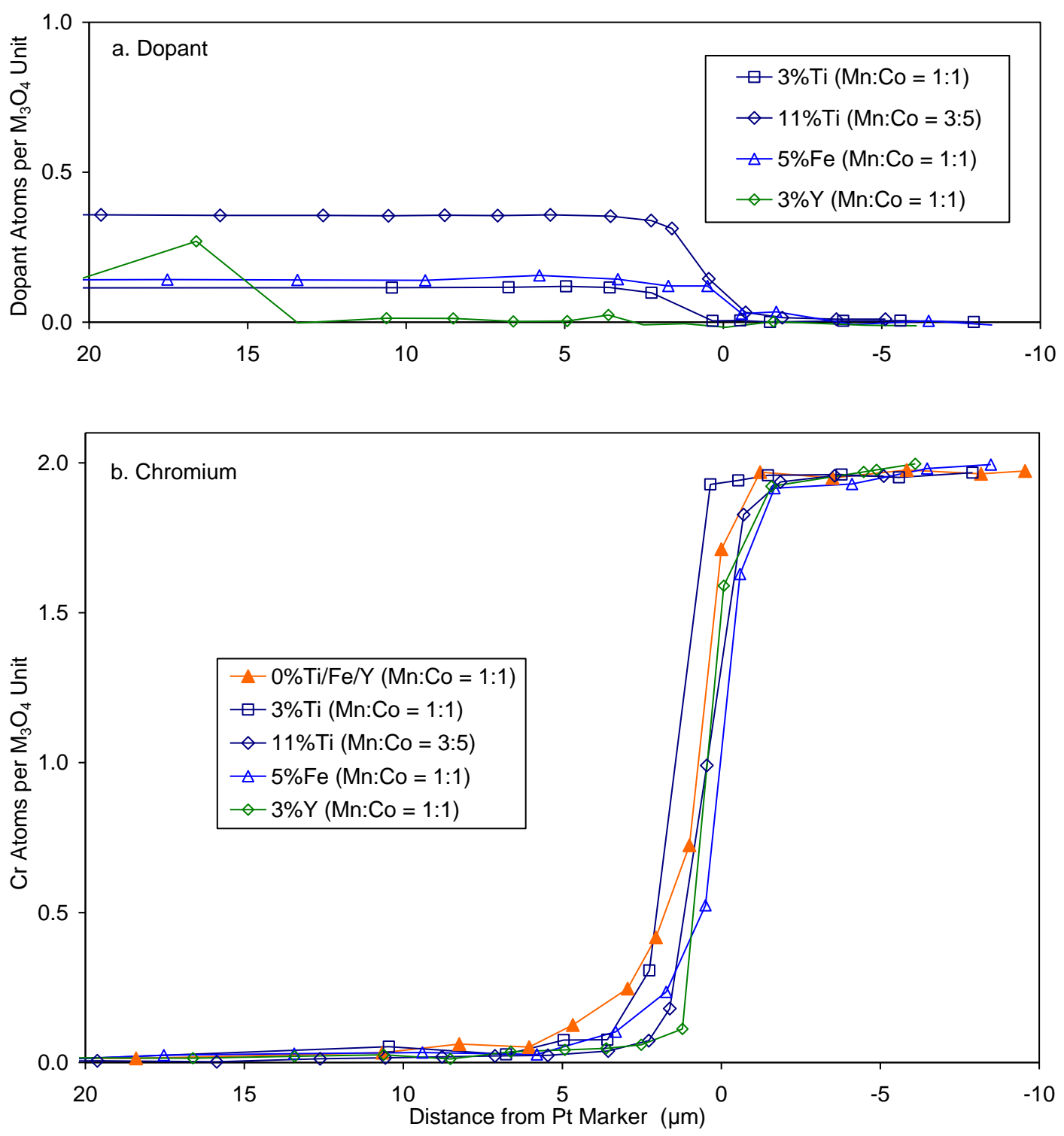

Figure 27. Dopant ( $\mathrm{Ti}, \mathrm{Fe}$ or $\mathrm{Y})(\mathrm{a})$ and chromium (b) concentration gradients in $(\mathrm{Mn}, \mathrm{Co}, \mathrm{M})_{3} \mathrm{O}_{4}(\mathrm{M}=$ $\mathrm{Ti}, \mathrm{Fe}, \mathrm{Y}$ ) after being in contact with $\mathrm{Cr}_{2} \mathrm{O}_{3}$ for 72 hours at $1000^{\circ} \mathrm{C}$. 


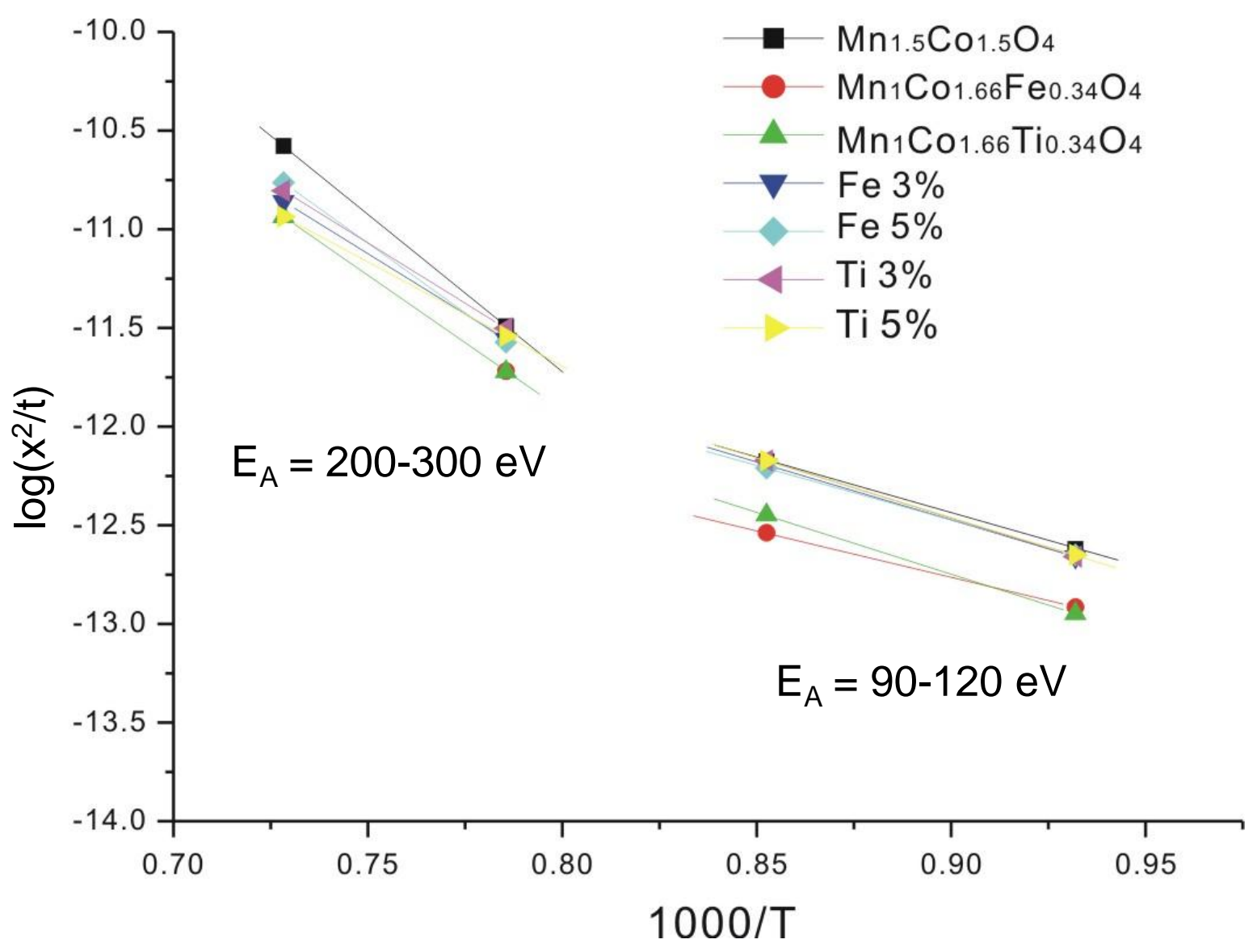

Figure 28. Effective diffusion coefficient $\left(x^{2} / t\right)$ for doped and undoped spinel reaction layers.

Since both iron and titanium were not present in the high-chromium spinel layer formed at the alloy-coating interface, they would likely not affect the properties of that highly resistive layer, which may be a major contribution to the overall resistance. To possibly provide added benefit by doping this layer, other elements that have a stronger preference for the octahedral site, particular nickel and copper were evaluated. X-ray diffraction spectra for nickel-and copper-doped sample after heat treatment at temperatures above $900^{\circ} \mathrm{C}$ formed the spinel phase. Figure 29 shows the phase content for the compositions $\mathrm{Mn}_{1.5} \mathrm{Co}_{0.6} \mathrm{Ni}_{0.9} \mathrm{O}_{4}$ and $\mathrm{Mn}_{1.5} \mathrm{Co}_{0.9} \mathrm{Cu}_{0.6} \mathrm{O}_{4}$ heat treated respectively at $1100^{\circ} \mathrm{C}$ and $1050^{\circ} \mathrm{C}$. All the observed reflections correspond to the cubic spinel structure. 


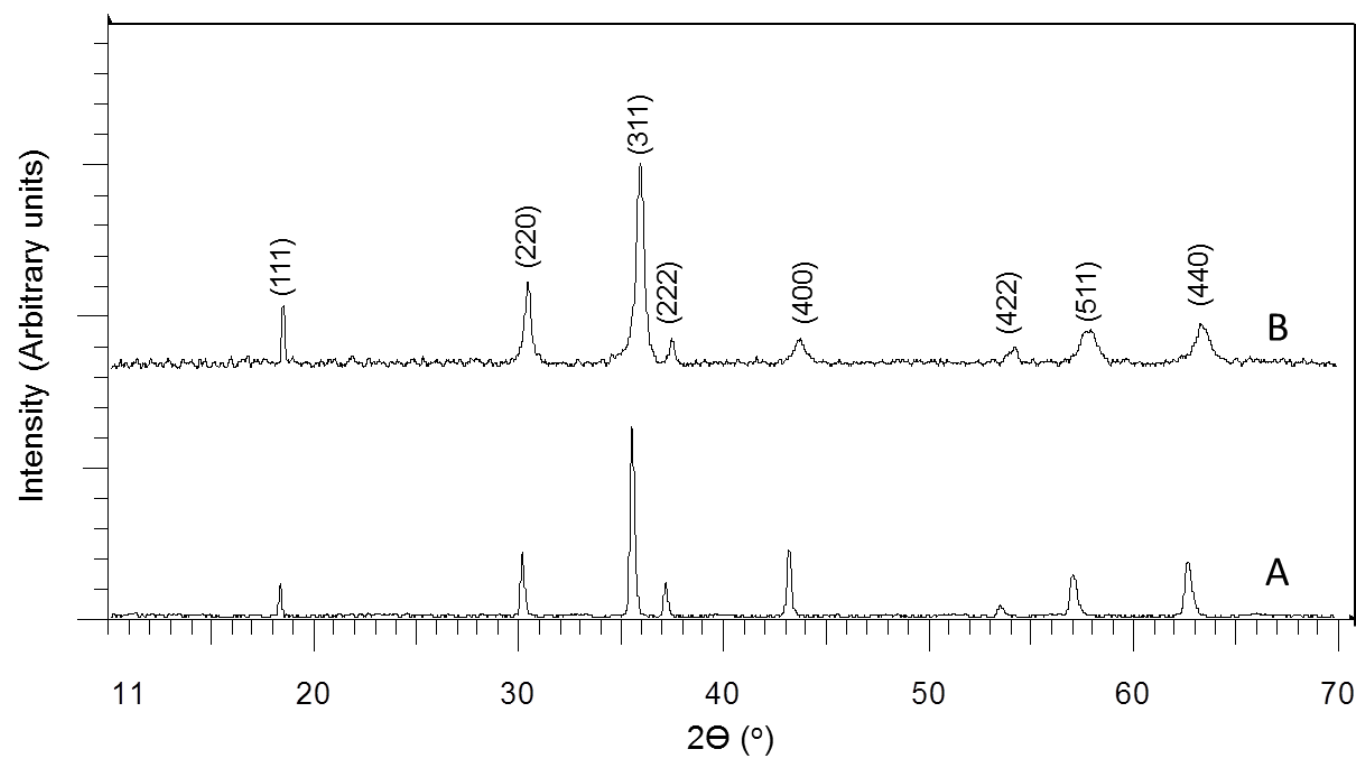

Figure 29. XRD of sintered pellets showing cubic spinel phase, $A-\mathrm{Mn}_{1.5} \mathrm{Co}_{0.6} \mathrm{Ni}_{0.9} \mathrm{O}_{4}$ sintered at $1100^{\circ} \mathrm{C}$ and $\mathrm{B}-\mathrm{Mn}_{1.5} \mathrm{Co}_{0.9} \mathrm{Cu}_{0.6} \mathrm{O}_{4}$ sintered at $1050^{\circ} \mathrm{C}$

Electron micrographs of $\mathrm{Mn}_{1.5} \mathrm{Co}_{1.5} \mathrm{O}_{4}$ (Figure 30), $\mathrm{Mn}_{1.5} \mathrm{Co}_{0.9} \mathrm{Cu}_{0.6} \mathrm{O}_{4}$ (Figure 31) and $\mathrm{Mn}_{1.5} \mathrm{Co}_{0.6} \mathrm{Ni}_{0.9} \mathrm{O}_{4}$ (Figure 32a) show that dense pellets could be obtained. Copper additions improved the sintering behavior, so a reasonably dense pellet could be obtained by sintering the copper-doped sample at $1050^{\circ} \mathrm{C}$, while a higher temperature $\left(1200^{\circ} \mathrm{C}\right)$ was required for the undoped and nickel-doped samples. Although all the x-ray diffraction peaks in $\mathrm{Mn}_{1.5} \mathrm{Co}_{0.6} \mathrm{Ni}_{0.9} \mathrm{O}_{4}$ could be attributed to the spinel phase, there appears to be two phases as shown in Figure 32a. The nickel-rich phase had a typical composition of $\mathrm{Mn}_{0.1} \mathrm{Co}_{0.1} \mathrm{Ni}_{0.8} \mathrm{O}_{x}$, while the matrix had a composition of $\mathrm{Mn}_{1.73} \mathrm{Co}_{0.74} \mathrm{Ni}_{0.53} \mathrm{O}_{4}$, which is close to that of the spinel. The existence of the nickel-rich phase was not evident in the XRD due to the possibility of the phase having a rock salt (cubic) structure, the peaks of which overlap with peaks of the spinel phase. This is consistent with the Ni-Mn-O phase diagram [23] which indicates a two-phase, spinel + rock salt, region exists for higher temperatures and nickel contents (e.g. T>760 $-1200^{\circ} \mathrm{C}$ for $\mathrm{Ni} /(\mathrm{Mn}+\mathrm{Ni})$ of $0.4-0.2)$. Phase diagrams are not available for the Ni-Mn-Co-O, but it is likely a similar trend occurs with the addition of cobalt. Taking cue from this phase diagram the sintered $\mathrm{Ni}$ doped composition was treated through an annealing step at $950^{\circ} \mathrm{C}$ for about 70 hours. This resulted in homogenization of the microstructure as evident from Figure 32b, which had uniform looking grains with a uniform composition. 


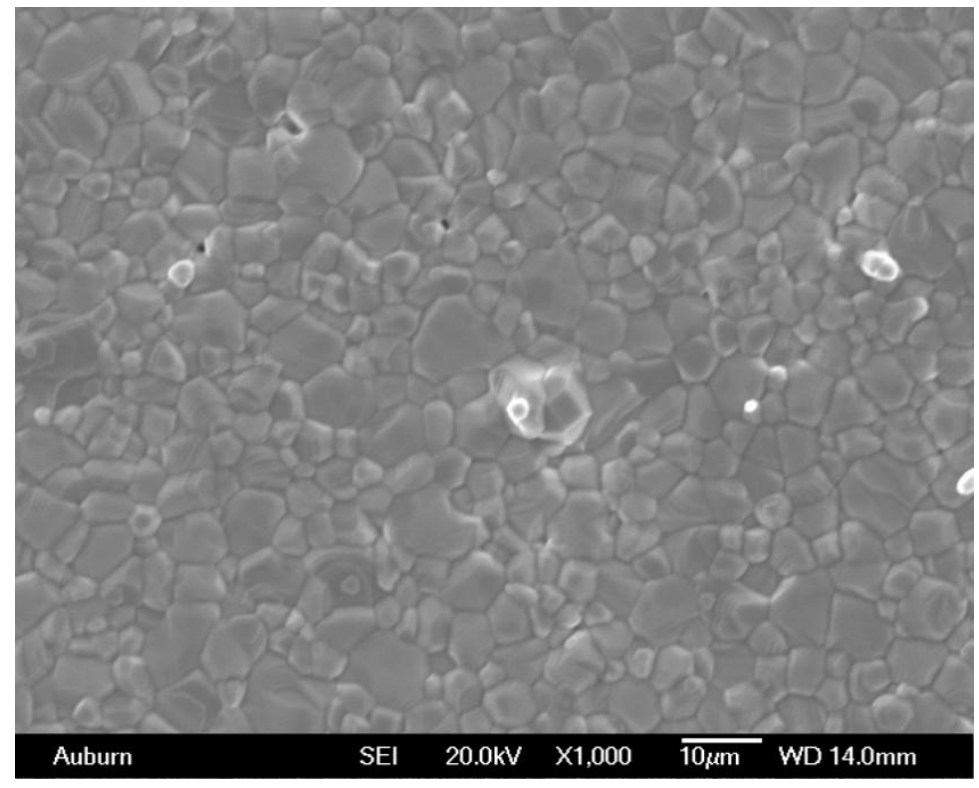

Figure 30. Electron micrograph of $\mathrm{Mn}_{1.5} \mathrm{Co}_{1.5} \mathrm{O}_{4}$ sintered at $1200^{\circ} \mathrm{C}$ depicting good sintering and grain growth.

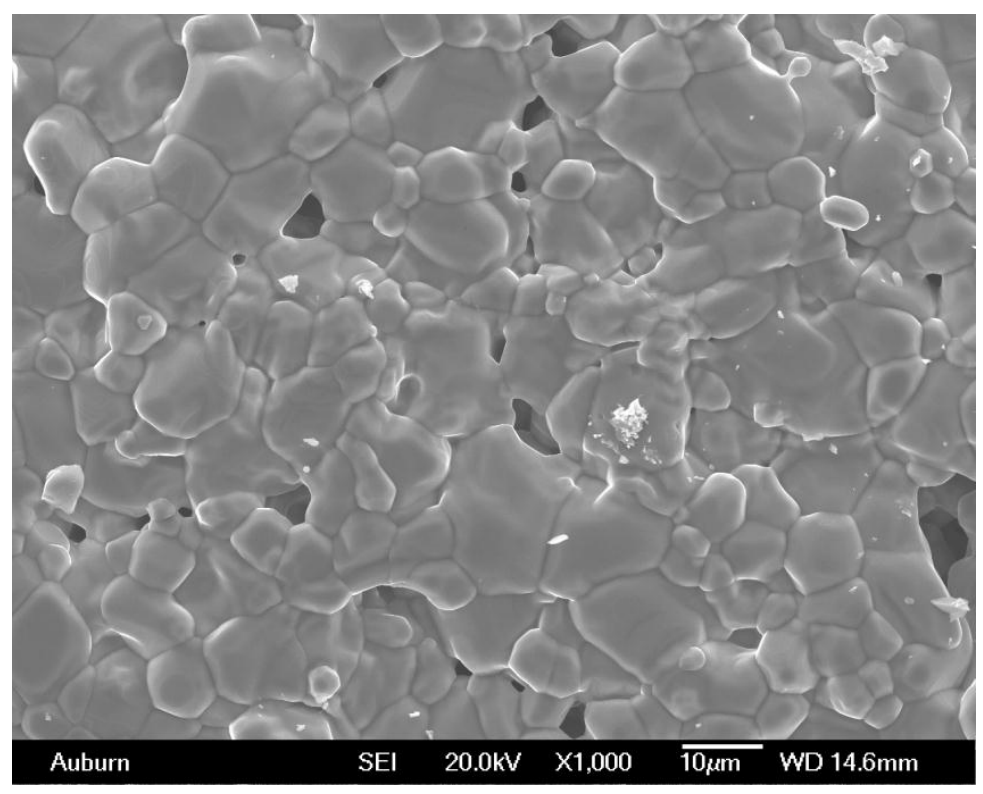

Figure 31. Microstructure of $\mathrm{Mn}_{1.5} \mathrm{Co}_{0.9} \mathrm{Cu}_{0.6} \mathrm{O}_{4}$ sintered at $1050^{\circ} \mathrm{C}$ with considerable grain growth. 


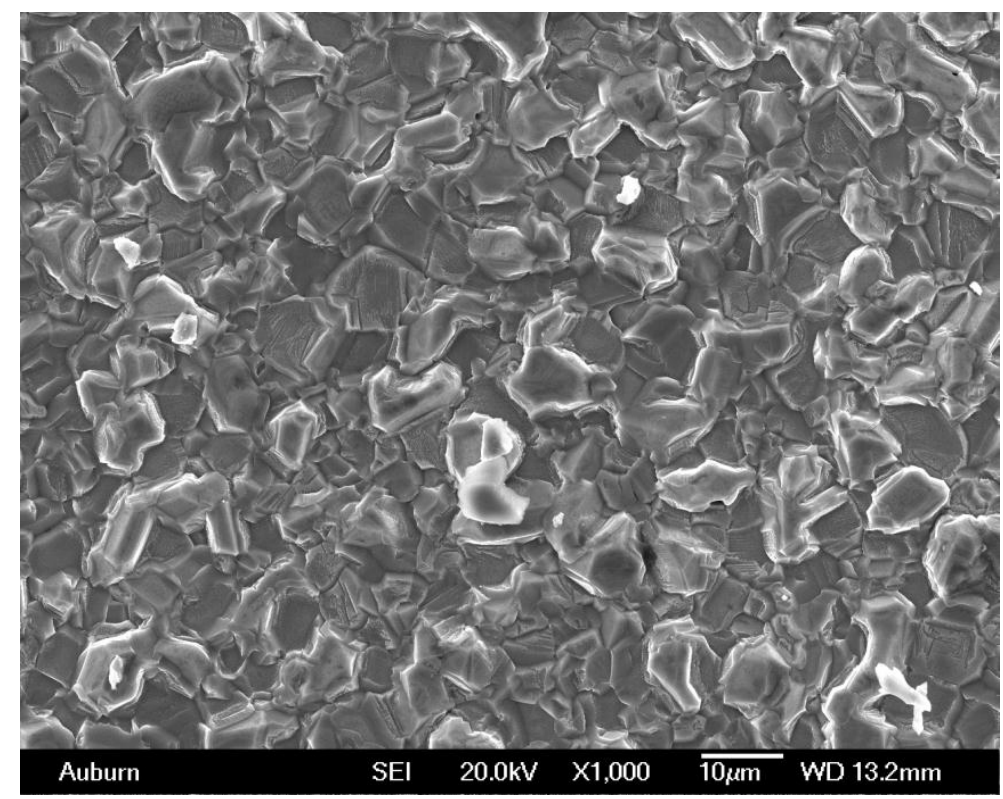

Figure 32a. Dense microstructure of $\mathrm{Mn}_{1.5} \mathrm{Co}_{0.6} \mathrm{Ni}_{0.9} \mathrm{O}_{4}$ sintered at $1200^{\circ} \mathrm{C}$ with Ni rich separated phase (N) and a largely spinel matrix phase (S).

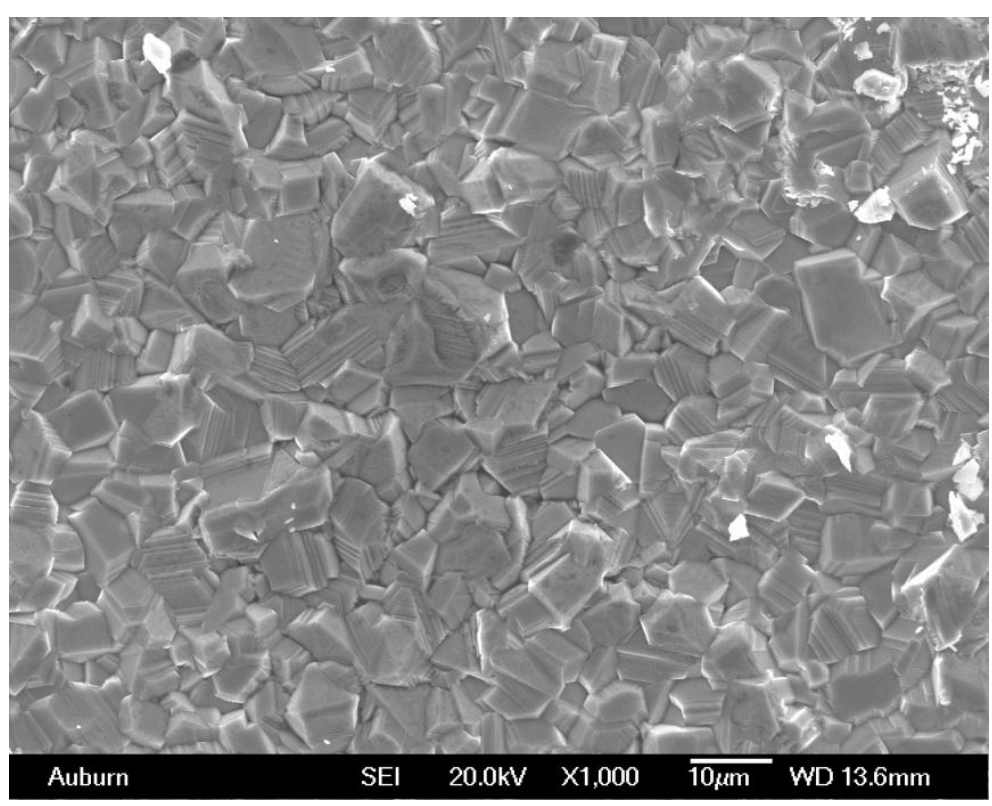

Figure 32b. Micrograph of sintered $\mathrm{Mn}_{1.5} \mathrm{Co}_{0.6} \mathrm{Ni}_{0.9} \mathrm{O}_{4}$ after annealing at $950^{\circ} \mathrm{C}$ showing change in morphology.

Although the surface microstructures of the nickel-doped compositions appear homogeneous after prolonged annealing, the polished cross section of the sintered pellets, Figure $33 \mathrm{a}$ and $33 \mathrm{~b}$, showed brighter regions in the microstructure. The EDS analysis of these regions confirmed that they are rich in nickel. The morphology of the separated nickel-rich phase suggests that they are precipitated at the grain boundaries. Modification of the annealing temperature and process helped in complete 
suppression of nickel-rich phase in $\mathrm{Mn}_{1.5} \mathrm{Co}_{0.9} \mathrm{Ni}_{0.6} \mathrm{O}_{4}$ (Figure 34a) and considerable reduction in case of $\mathrm{Mn}_{1.5} \mathrm{Co}_{0.6} \mathrm{Ni}_{0.9} \mathrm{O}_{4}$ as evident from Figure 34b.

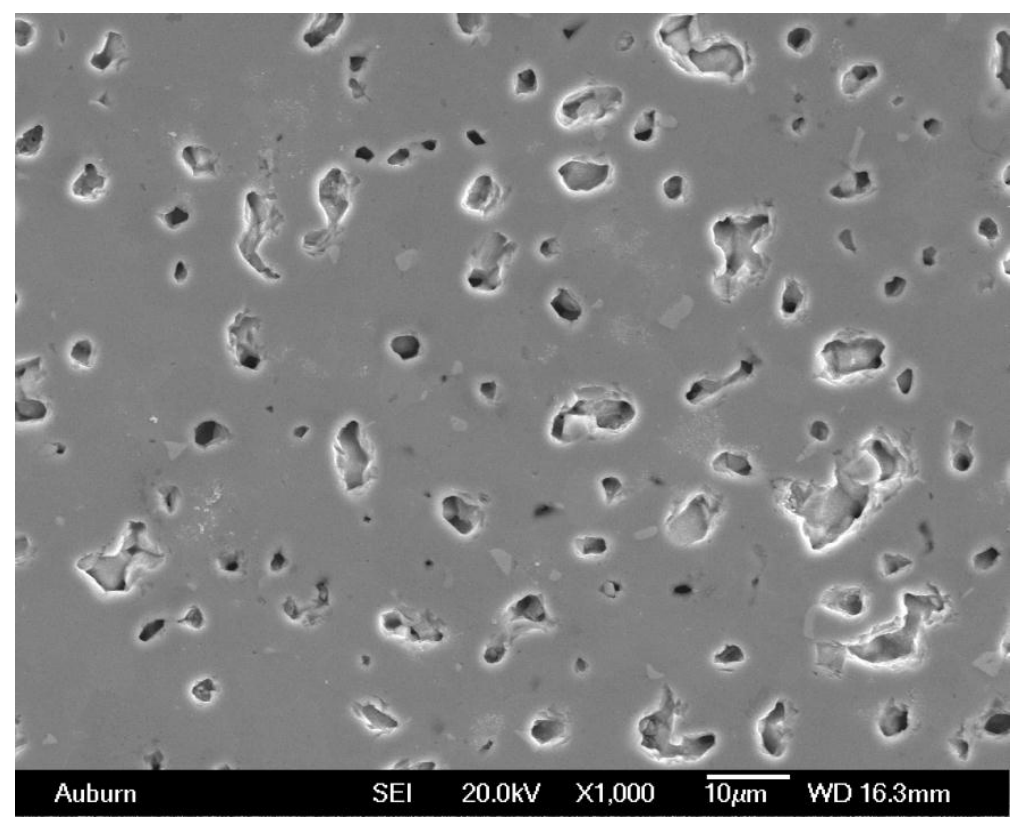

Figure 33a. Cross section of $1200^{\circ} \mathrm{C}$ sintered $\mathrm{Mn}_{1.5} \mathrm{Co}_{0.9} \mathrm{Ni}_{0.6} \mathrm{O}_{4}$ with Ni-rich separate phase

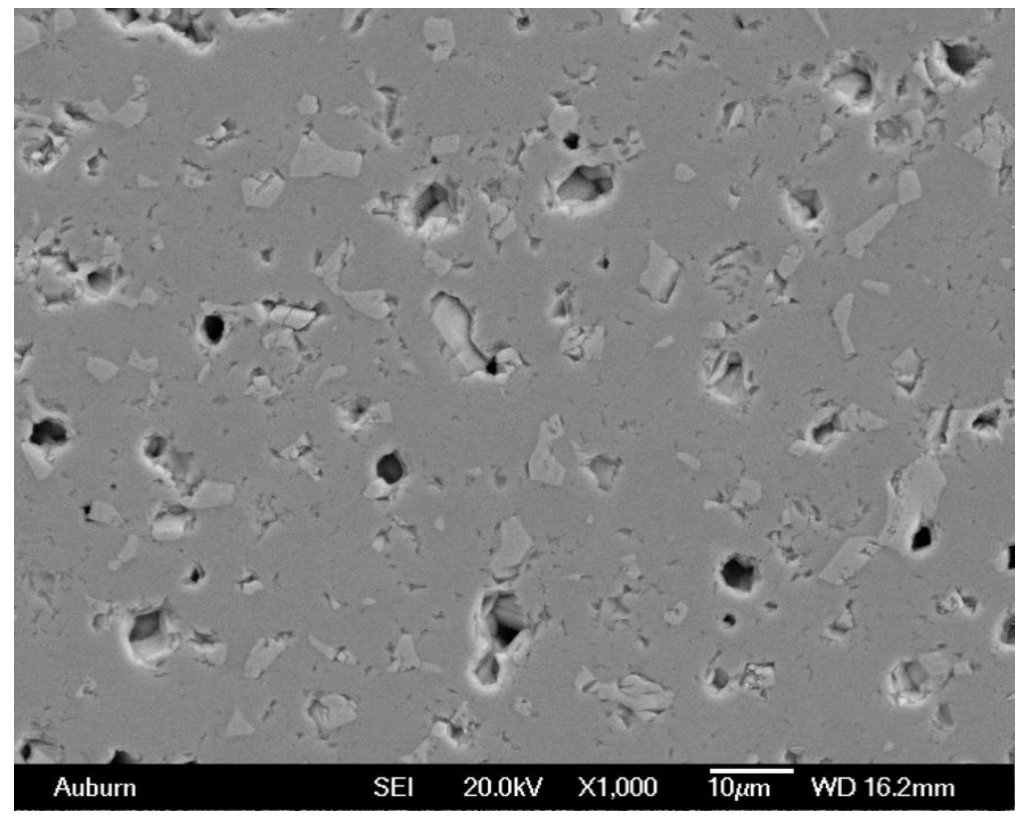

Figure 33b. Considerable amount of $\mathrm{Ni}$ rich phase in sintered $\mathrm{Mn}_{1.5} \mathrm{Co}_{0.6} \mathrm{Ni}_{0.9} \mathrm{O}_{4}$ annealed at $950^{\circ} \mathrm{C}$ 


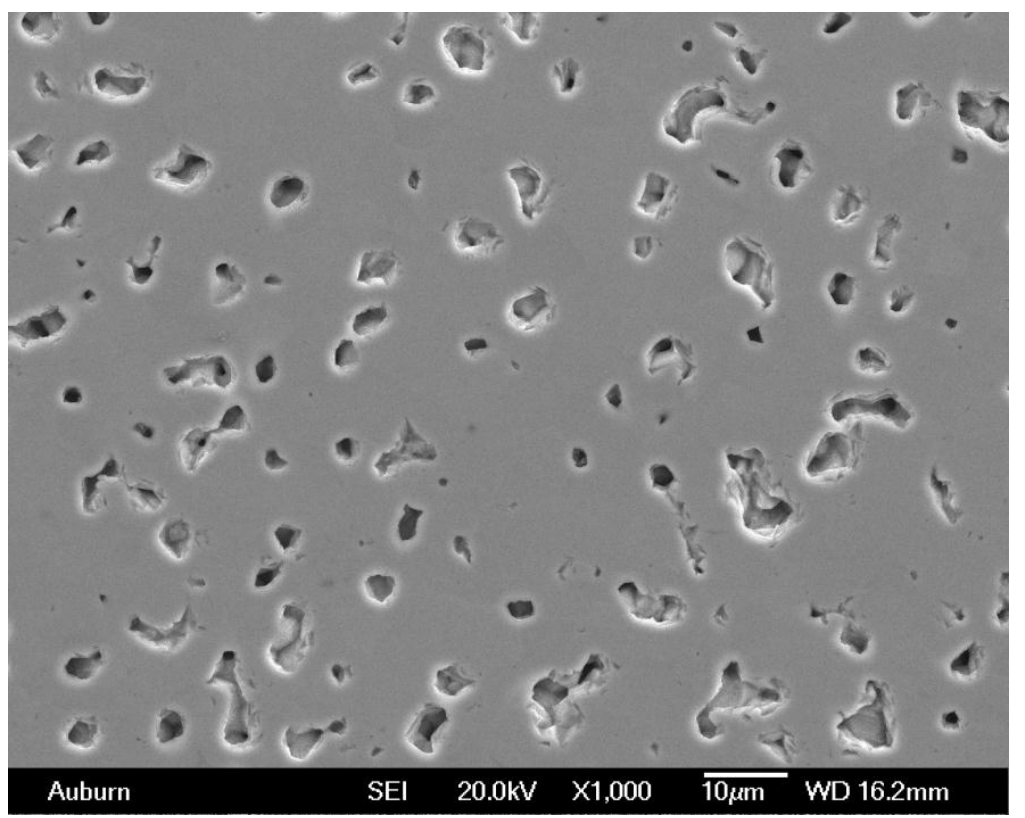

Figure 34a. $\mathrm{Mn}_{1.5} \mathrm{Co}_{0.9} \mathrm{Ni}_{0.6} \mathrm{O}_{4}$ after modified annealing showing absence of $\mathrm{Ni}$ rich separate phase.

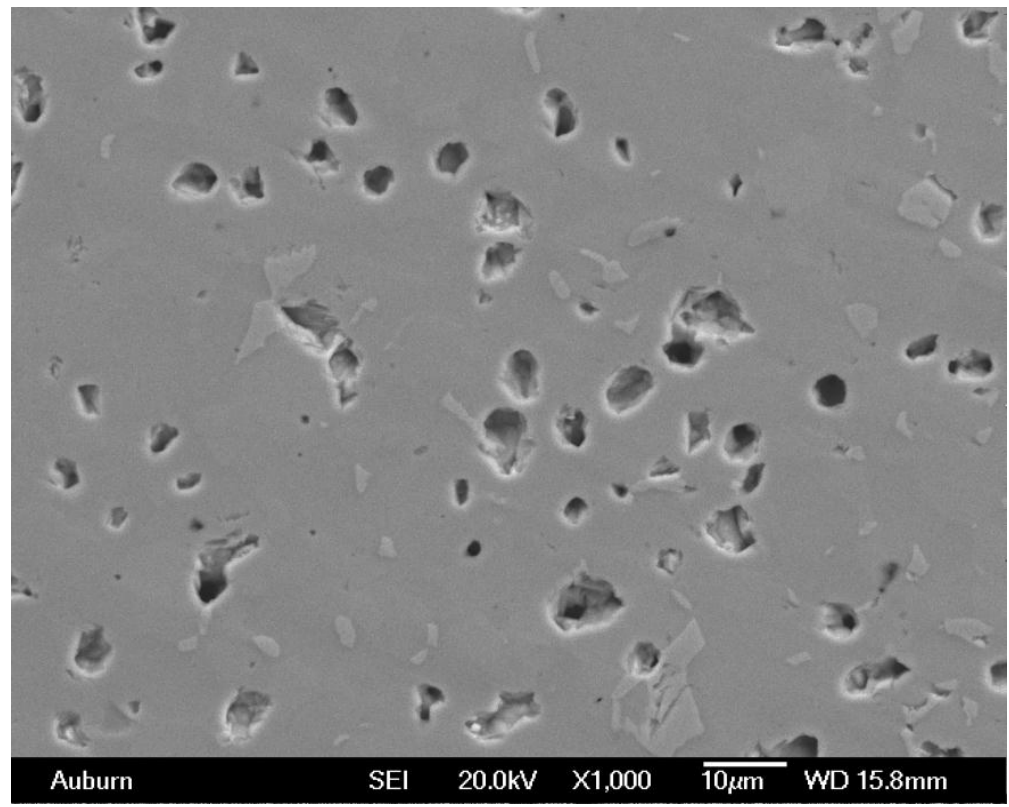

Figure 34b. Polished cross section of $\mathrm{Mn}_{1.5} \mathrm{Co}_{0.6} \mathrm{Ni}_{0.9} \mathrm{O}_{4}$ after annealing showing reduction in $\mathrm{Ni}$ rich phase

The replacement of cobalt with nickel in $\mathrm{Mn}_{1.5} \mathrm{Co}_{1.5} \mathrm{O}_{4}$ leads to a small decrease in conductivity. However, as shown in Figure 35, the conductivity is still in the same range as $(\mathrm{Mn}, \mathrm{Co})_{3} \mathrm{O}_{4}$ and is higher than chromium-containing composition. The reactivity of nickel-doped composition $\mathrm{Mn}_{1.5} \mathrm{CoNi}_{0.5} \mathrm{O}_{4}$ was evaluated using a diffusion couple with $\mathrm{Cr}_{2} \mathrm{O}_{3}$. Figure 36 shows the chromium concentration gradient for undoped and nickel-doped spinel samples and indicates that the thickness of the high-chromium spinel 
is less in the nickel-doped sample. This is similar to results for iron and titanium additions shown in previous reports. One difference between the behavior of nickel-doped samples and iron- or titaniumdoped samples, is that in the latter cases, the dopant, iron or titanium, was not observed in the highchromium spinel layer, but, as shown in Figure 37, nickel is present in the high-chromium spinel layer. As previously observed for diffusion couples with $\mathrm{Cr}_{2} \mathrm{O}_{3}$, the surface of the high-chromium spinel layer is faceted, but in this case $2 \%$ nickel was observed at the surface.

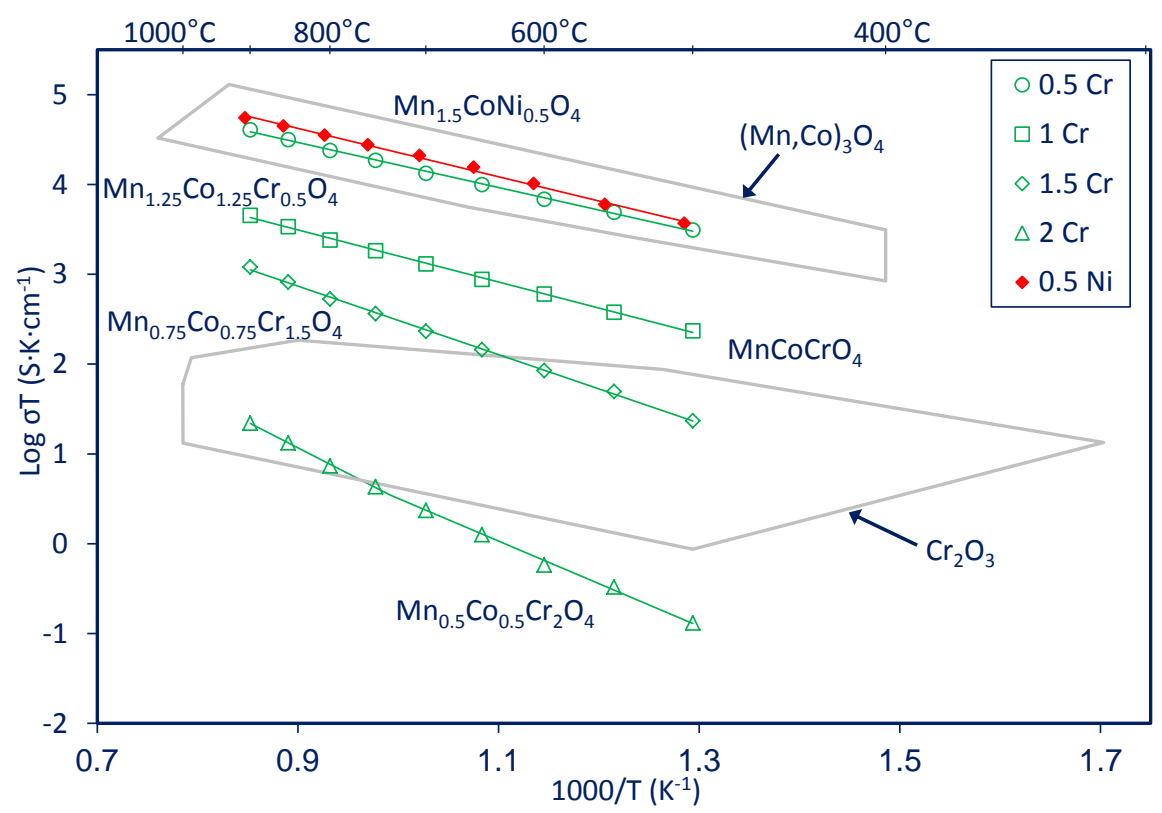

Figure 35. Conductivity of $(\mathrm{Mn}, \mathrm{Co})_{3-\mathrm{x}} \mathrm{Cr}_{x} \mathrm{O}_{4},(\mathrm{Mn}, \mathrm{Co})_{3} \mathrm{O}_{4}$ and $(\mathrm{Mn}, \mathrm{Co}, \mathrm{Ni})_{3} \mathrm{O}_{4}$ in air.

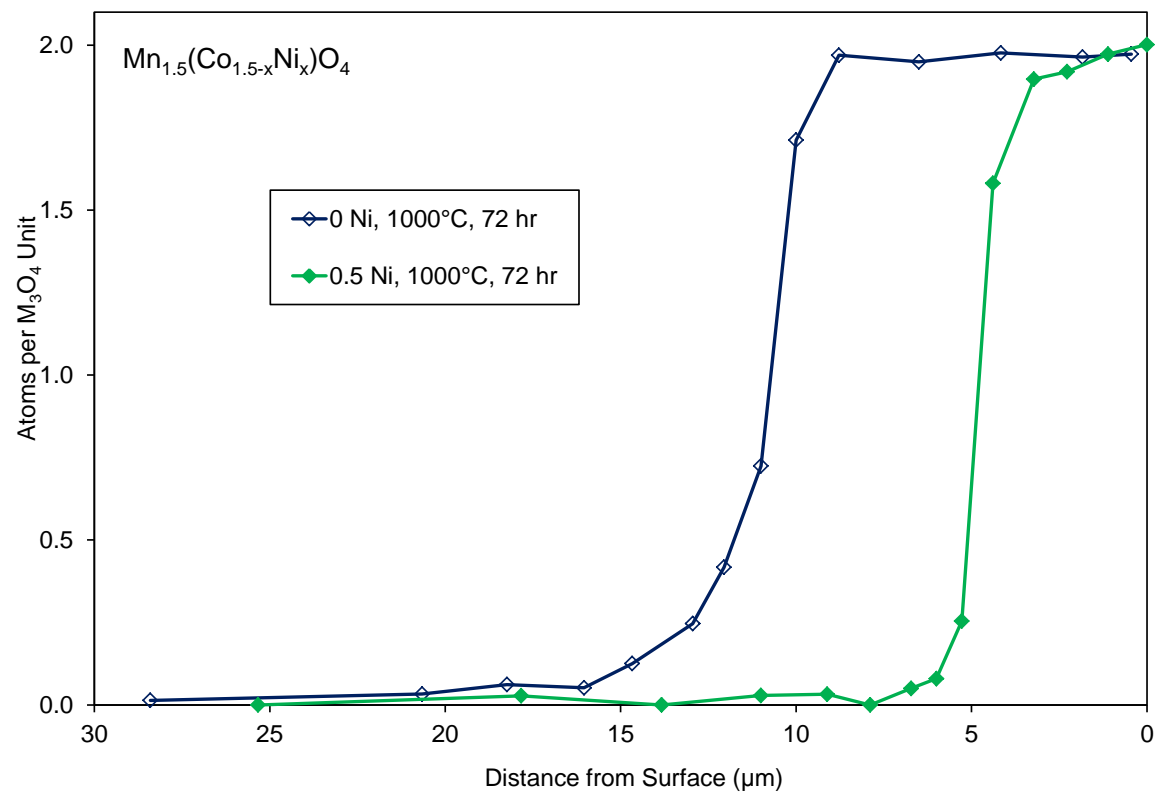

Figure 36. Chromium concentration gradient in $\mathrm{Mn}_{1.5} \mathrm{Co}_{1.5} \mathrm{O}_{4}$ and $\mathrm{Mn}_{1.5} \mathrm{CoNi}_{0.5} \mathrm{O}_{4}$ after reaction with $\mathrm{Cr}_{2} \mathrm{O}_{3}$ for 72 hours in air at $1000^{\circ} \mathrm{C}$. 

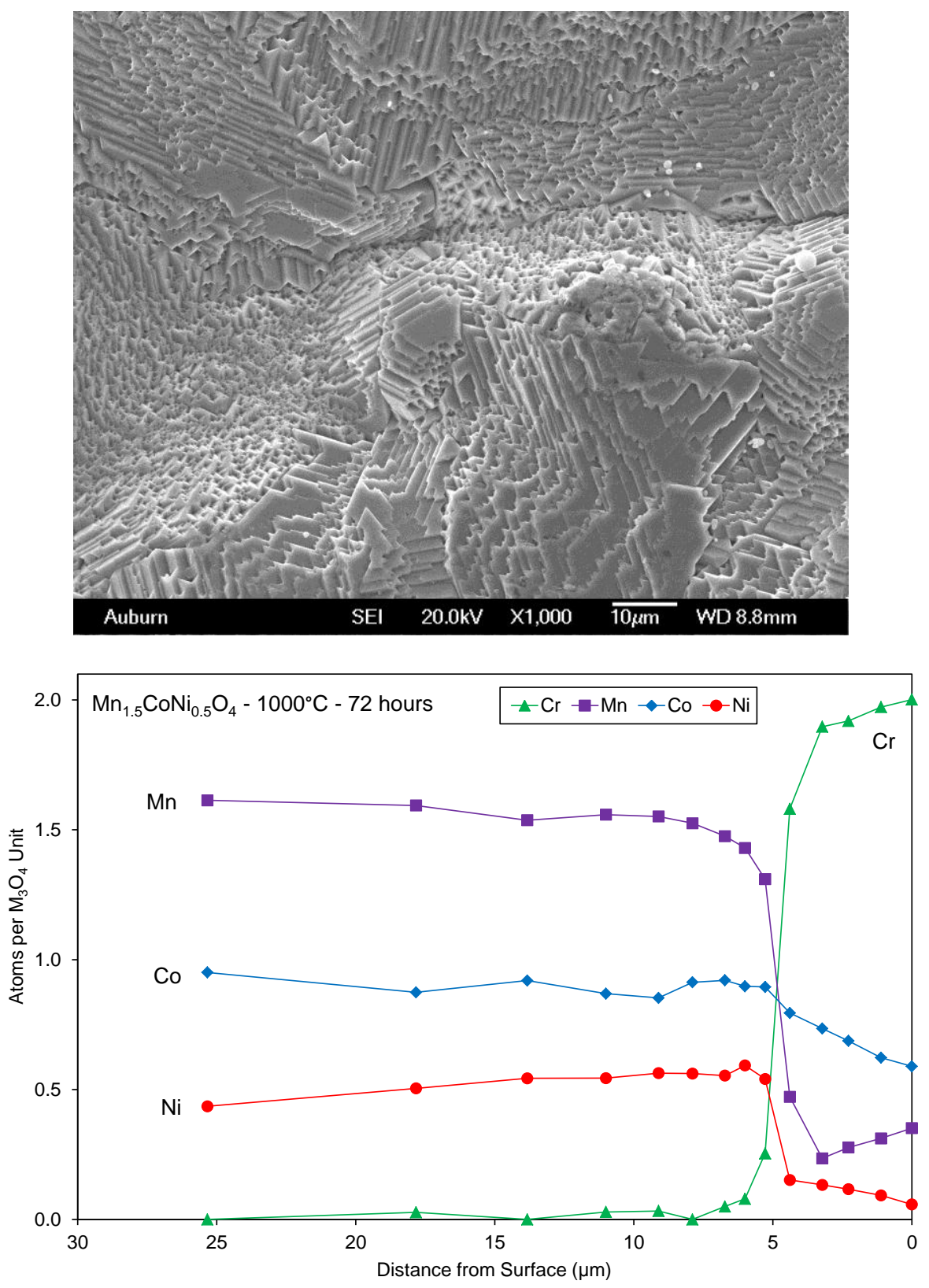

Figure 37. SEM micrograph of surface morphology (a) and cross section EDS composition profile (b) of $\mathrm{Mn}_{1.5} \mathrm{CoNi}_{0.5} \mathrm{O}_{4}$ after reaction with $\mathrm{Cr}_{2} \mathrm{O}_{3}$ for 72 hours in air at $1000^{\circ} \mathrm{C}$. 


\section{Alloy-Spinel Diffusion Couples}

The diffusion couples discussed above were between spinel oxide pellets and $\mathrm{Cr}_{2} \mathrm{O}_{3}$ pellets. This is similar to an alloy and allows for high temperature accelerated tests, but there are some differences. One is that the chromia scale can contain elements from the steel. In particular, manganese in typically observed in the scales formed on ferritic stainless steel used for SOFC interconnects. The manganese is usually present as a spinel phase on the surface of the chromia scale, but is not observed in the chromia phase. In this work, the solubility of manganese in chromia was evaluated by heating a diffusion couple of $\mathrm{Cr}_{2} \mathrm{O}_{3}$ and $\mathrm{MnO}$ to $1200^{\circ} \mathrm{C}$ for 72 hours. A spinel phase formed between at the interface and only a small amount (less than 1\%) of manganese was present in the chromia phase. This is consistent with the results from oxidation tests and indicates that only small amount of manganese can dissolve in chromia, but the diffusion rate is relatively fast. Thus, in a diffusion couple between the ferritic stainless steel and the spinel phase, the alloy is an additional source of manganese. Other important alloy additions in SS 441 are titanium and niobium, which have also been observed in the oxide scales.

To evaluate possible differences between $\mathrm{Cr}_{2} \mathrm{O}_{3}$ and the oxide scale on stainless steels, diffusion couples between a ferritic stainless steel (SS 441) and the spinel oxide pellets were also studied. Sintered pellets of spinel oxides and the metal plate were ground in several steps using SiC abrasive paper to obtain smooth and flat surfaces, and the final polishing was done at 2000 grit. To ensure proper contact between the surfaces a weight of 50 grams was placed on the pellet during the heat treatment process. The heat treatment was carried out in a tube furnace at $800^{\circ} \mathrm{C}$ or $900^{\circ} \mathrm{C}$ for 100 hours in air.

The diffusion couple experiments revealed important similarities and differences between the reaction of dense spinel oxide pellets with chromia and with the chromia scale formed on interconnect alloys. There was good adhesion between spinel pellet and metal plate in case of the diffusion couple between $\mathrm{Mn}_{1.5} \mathrm{Co}_{1.5} \mathrm{O}_{4}$ and SS-441 heat treated at $800^{\circ} \mathrm{C}$ for 100 hours and the cross section of this interface is shown in Figure 38. $\mathrm{A} \mathrm{Cr}_{2} \mathrm{O}_{3}$ layer with a thickness of about $1 \mu \mathrm{m}$ forms on the alloy surface as indicated by the region with a high constant chromium concentration. Between this $\mathrm{Cr}_{2} \mathrm{O}_{3}$ layer and the original spinel composition an interaction layer having high chromium spinel composition with Co: $\mathrm{Mn}$ ratio higher than that in the original composition is formed. This resembles the behavior observed in diffusion couple experiments involving pure chromium oxide and sintered pellets described above, although the thickness of the chromium rich spinel layer is relatively thinner.

Similar behavior was observed in the case of a diffusion couple involving the $\mathrm{Ni}$ doped composition $\left(\mathrm{Mn}_{1.5} \mathrm{Co}_{0.9} \mathrm{Ni}_{0.6} \mathrm{O}_{4}\right)$ and SS-441 as evident from Figure 39. A chromia scale of about $1 \mu \mathrm{m}$ thickness followed by a high chromia spinel region with decreasing chromium content and higher cobalt 
content is formed. As in the diffusion couples with $\mathrm{Cr}_{2} \mathrm{O}_{3}$, nickel is present in the high-chromium spinel layer, which can alter the electrical characteristics of the interaction layer and affect the degradation mechanism. Although there is good adhesion between the pellet and plate a discontinuous gap between the chromia scale and the high chromium spinel layer is also observed as in the case of the diffusion couple with un-doped spinel.

The cross section of the diffusion couple between $\mathrm{Mn}_{1.5} \mathrm{Co}_{1.5} \mathrm{O}_{4}$ and $\mathrm{SS}-441$ heat treated at $900^{\circ} \mathrm{C}$ for 100 hours as well as the concentration of the different constituents across the interface are shown in Figure 40. The behavior is different from that of the $800^{\circ} \mathrm{C}$ diffusion couples in that the high chromium spinel layer is absent. A relatively thicker $\mathrm{Cr}_{2} \mathrm{O}_{3}$ scale fills the space between the alloy and spinel layers, which indicates that there are differences in the growth kinetics between the chromia scale and the high-chromium spinel layer at $800^{\circ}$ and $900^{\circ} \mathrm{C}$. 


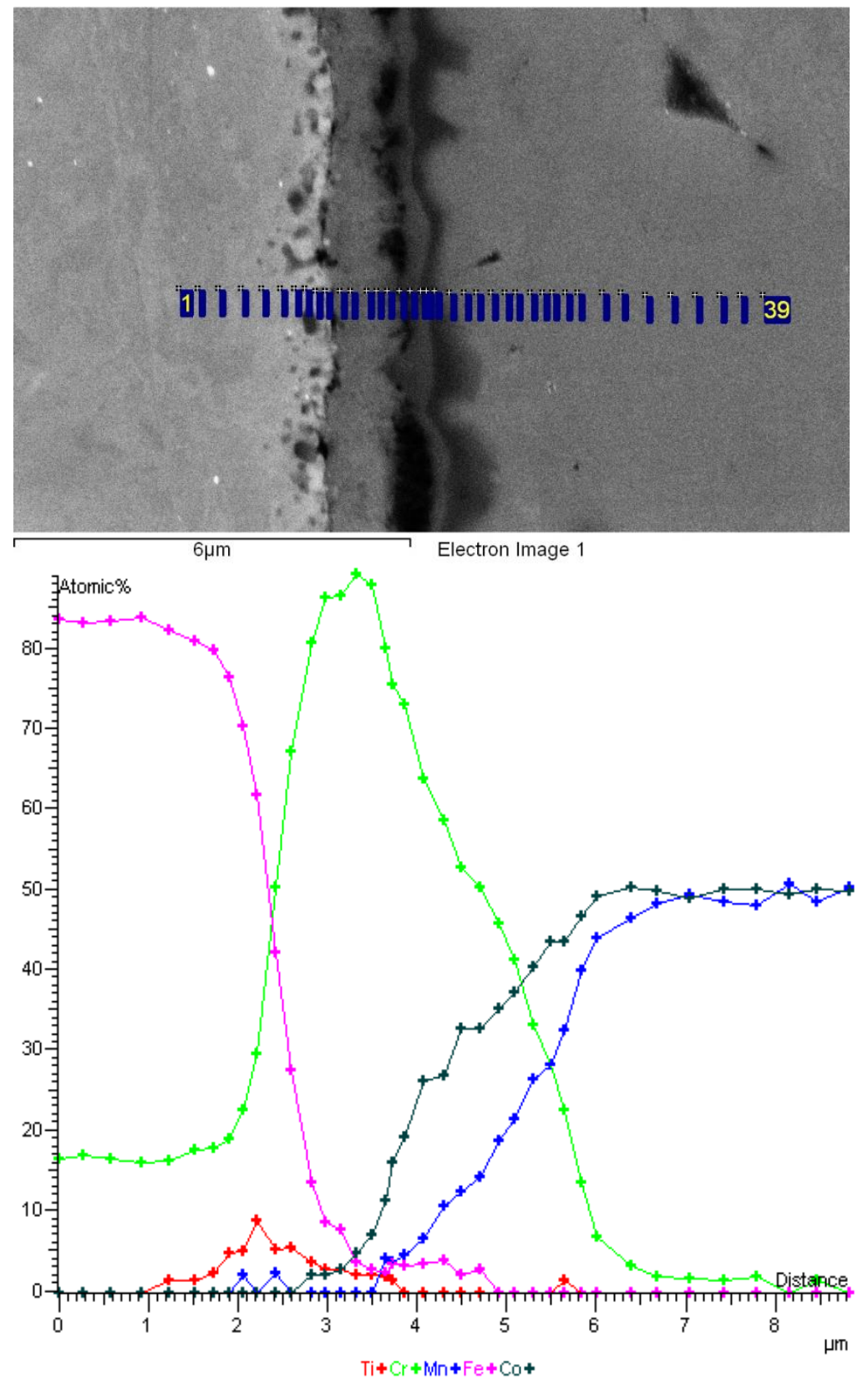

Figure 38 Cross section of the diffusion couple between $\mathrm{Mn}_{1.5} \mathrm{Co}_{1.5} \mathrm{O}_{4}$ and SS-441 after $100 \mathrm{~h}$ at $800^{\circ} \mathrm{C}$ (a), and the corresponding concentration gradient of constituents across the interface (b) 

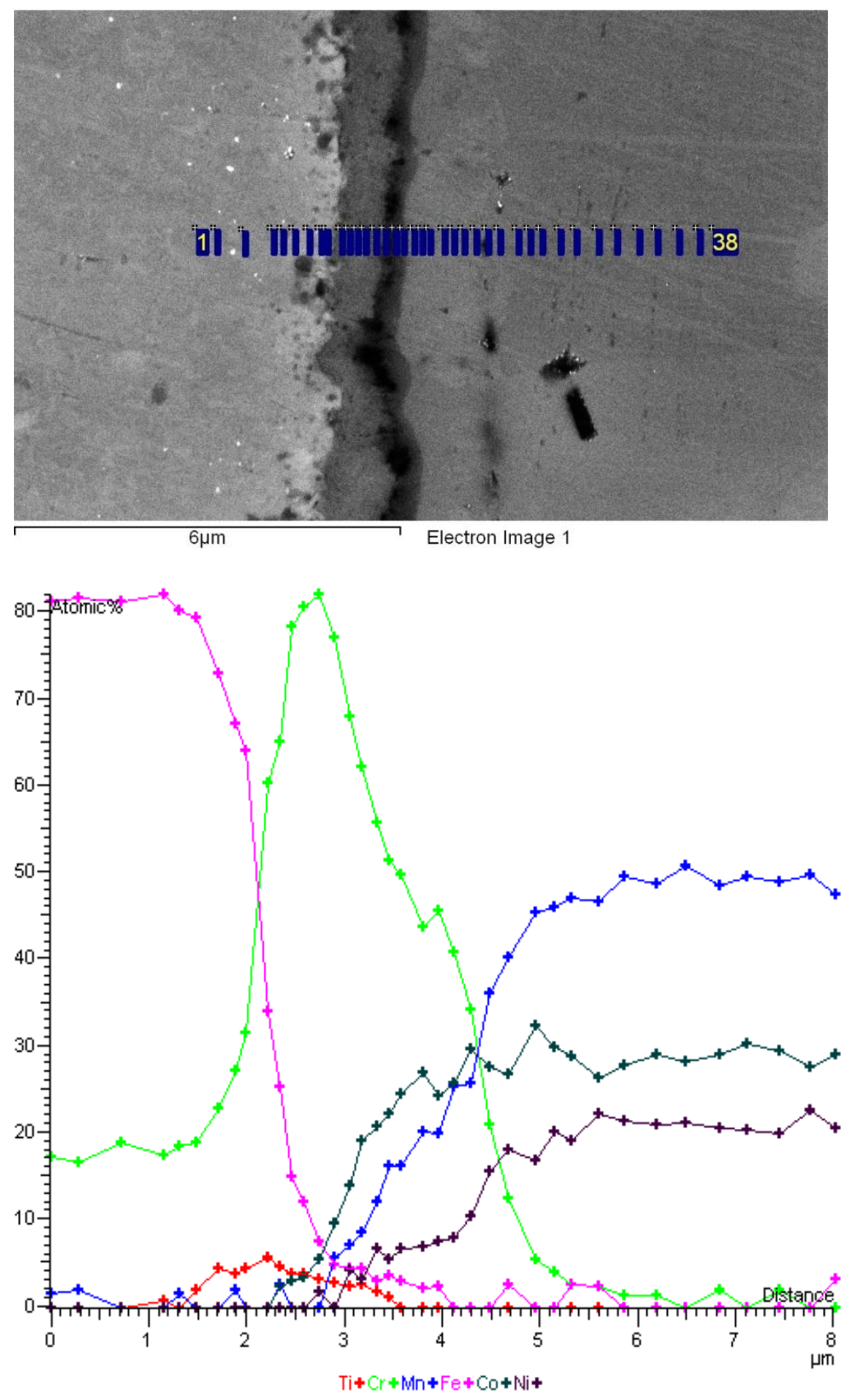

Figure 39. Interface of the $\mathrm{Mn}_{1.5} \mathrm{Co}_{0.9} \mathrm{Ni}_{0.6} \mathrm{O}_{4}$ - alloy diffusion couple after $100 \mathrm{~h}$ at $800^{\circ} \mathrm{C}$ with a high chromium spinel reaction layer with nickel content. 

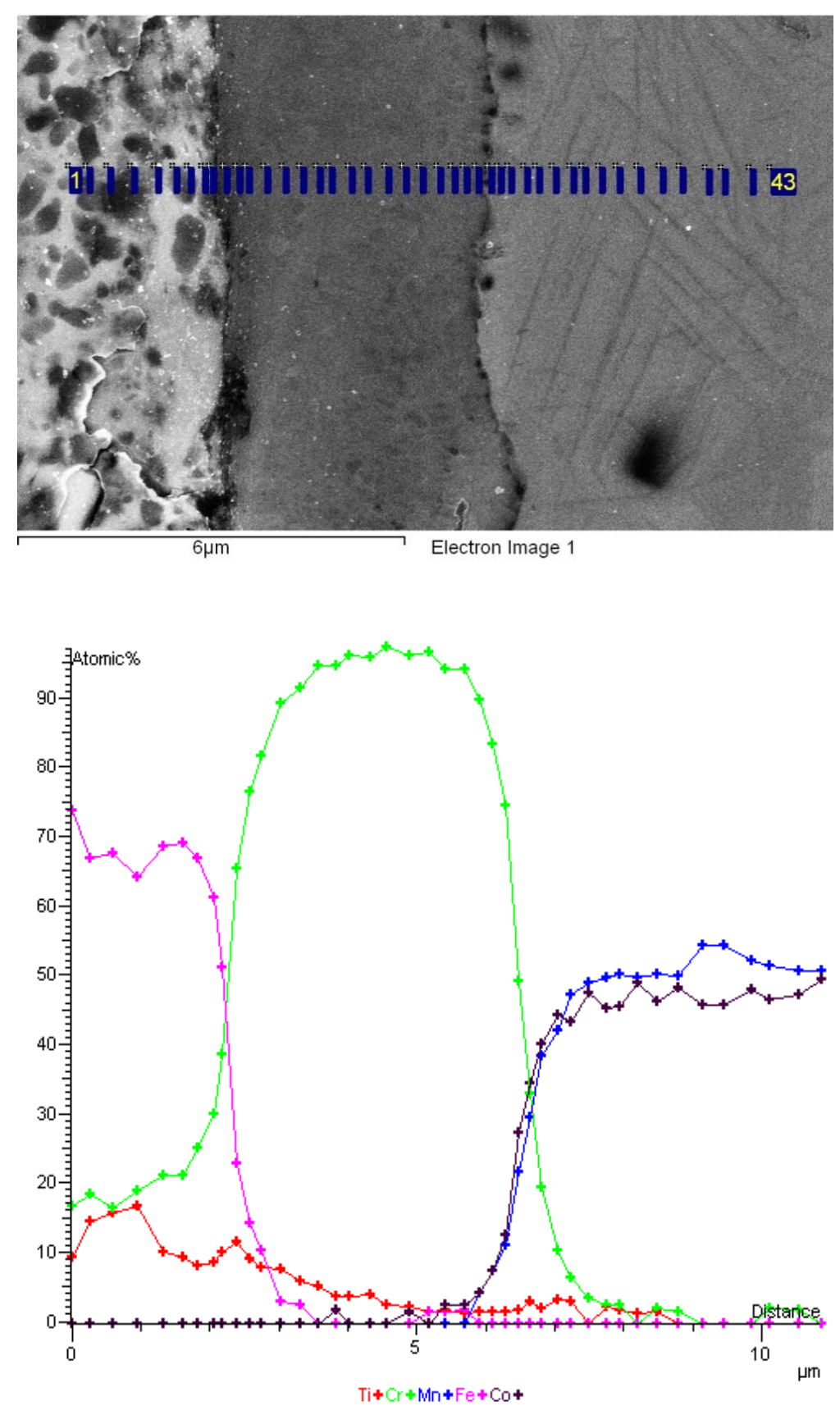

Figure $40 . \mathrm{Mn}_{1.5} \mathrm{Co}_{1.5} \mathrm{O}_{4}-\mathrm{SS} 441$ diffusion couple after $100 \mathrm{~h}$ at $900^{\circ} \mathrm{C}$ showing a thicker oxide scale at interface (a) and the change in concentration of the components showing an absence of chromium rich spinel layer (b) 
In the case of the diffusion couple involving $\mathrm{Mn}_{1.5} \mathrm{Co}_{0.9} \mathrm{Ni}_{0.6} \mathrm{O}_{4}$, after 100 hours at $900^{\circ} \mathrm{C}$, a relatively thinner oxide scale is observed compared to the un-doped composition as evident from Figure 41. The chromium content decreases sharply beyond the $\mathrm{Cr}_{2} \mathrm{O}_{3}$ scale indicating absence of the highchromium spinel layer. The cross section of the SS441- $\mathrm{Mn}_{1.5} \mathrm{Co}_{0.9} \mathrm{Cu}_{0.6} \mathrm{O}_{4}$ diffusion couple heat treated at $900^{\circ} \mathrm{C}$ for 100 hours, shown in Figure 42 , also has a thinner chromia scale as in case of nickel-doped composition. The chromium-rich spinel region is also not observed. These experiments confirm that the doping of the spinel can influence the growth of chromia scale on the alloy and is suppressed in case of nickel- and copper-doped Mn-Co spinel oxides.

Even though the initial experiment involving $\mathrm{Mn}_{1.5} \mathrm{Co}_{0.6} \mathrm{Ni}_{0.9} \mathrm{O}_{4}$ and the alloy at $900^{\circ} \mathrm{C}$ for 100 hours resulted in poor adhesion, the composition of the reaction layer formed on the surface of the spinel pellet provides insight on the mechanism of high-chromium spinel formation. The profile of the elements from the edge of the pellet, which was in contact with the alloy, is shown in Figure 43. A thick high-chromium spinel layer with increased Co:Mn ratio as compared to the original spinel phase is present. This is similar to the behavior observed in the case of experiments involving pure $\mathrm{Cr}_{2} \mathrm{O}_{3}$ and spinel pellets described above. The diffusion couples heat treated at $800^{\circ} \mathrm{C}$ discussed earlier also showed a similar behavior, but with a high-chromium spinel layer that is thinner due to the slower kinetics. Interestingly, a repeat of the experiment with $\mathrm{Mn}_{1.5} \mathrm{Co}_{0.6} \mathrm{Ni}_{0.9} \mathrm{O}_{4}$ and alloy resulted in a diffusion couple with good adhesion. The cross section shown in Figure 39 does not contain the high-chromium spinel layer, and contains a thinner chromia scale as in the case of $\mathrm{Mn}_{1.5} \mathrm{Co}_{0.9} \mathrm{Ni}_{0.6} \mathrm{O}_{4}$. This variability in the formation of the high-chromium spinel is in contrast to the diffusion couple experiments involving $\mathrm{Cr}_{2} \mathrm{O}_{3}$ and spinel pellets where a high-chromium spinel phase was always observed.

Although the original spinel oxide composition and the high-chromia spinel reaction layer both form the spinel structure, the sharp concentration gradients at the interface between these two layers suggests that there is a miscibility gap in the spinel solid solution. In this case, the high-chromium spinel layer needs to nucleate as a separate phase, rather than result from a continuously increasing chromium composition. If chromium is transported to the spinel oxide surface, a new high-chromium spinel phase can nucleate on the surface. If however, the spinel oxide is in intimate contact with the chromium source, nucleation of the high-chromium spinel phase may be inhibited, perhaps by mechanical constraints. Thus, even for the same composition (e.g. $\mathrm{Mn}_{1.5} \mathrm{Co}_{0.6} \mathrm{Ni}_{0.9} \mathrm{O}_{4}$ ) the high chromium spinel phase forms in areas where a gap is present (e.g. Figure 43), but not in those where the contact is good (e.g. Figure 44). In the case of diffusion couples with $\mathrm{Cr}_{2} \mathrm{O}_{3}$ pellets the poor sinterability of $\mathrm{Cr}_{2} \mathrm{O}_{3}$ will prevent good contact between the two pellets, so gas phase transport will likely dominate. 

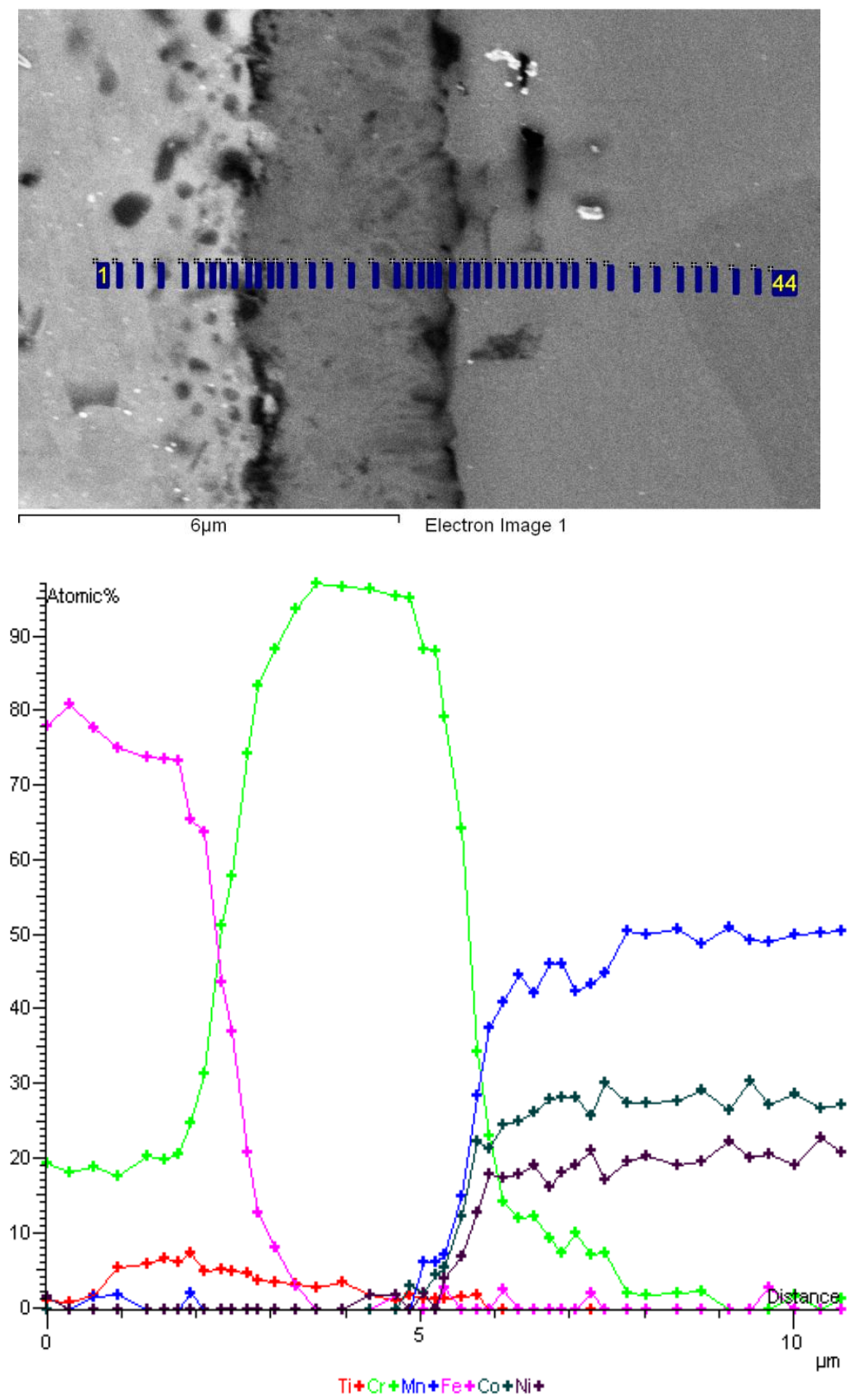

Figure 41. Cross section of the SS441- $\mathrm{Mn}_{1.5} \mathrm{Co}_{0.9} \mathrm{Ni}_{0.6} \mathrm{O}_{4}$ diffusion couple after $100 \mathrm{~h}$ at $900^{\circ} \mathrm{C}(\mathrm{a})$ and the corresponding profile of elements across the interface (b) 

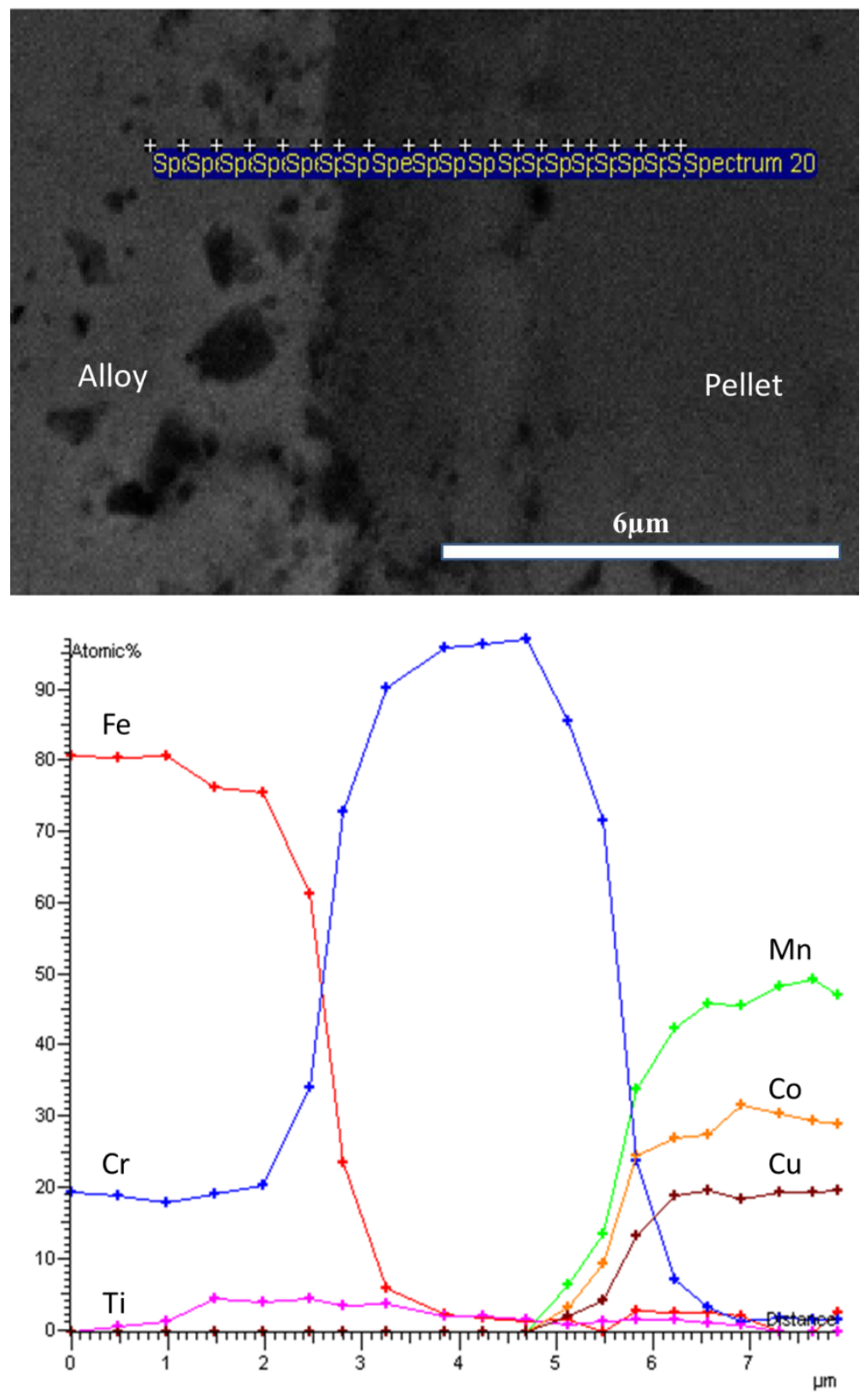

Figure 42. SS $441-\mathrm{Mn}_{1.5} \mathrm{Co}_{0.9} \mathrm{Cu}_{0.6} \mathrm{O}_{4}$ diffusion couple showing a thinner $\mathrm{Cr}_{2} \mathrm{O}_{3}$ layer (a) and the absence of chromium rich spinel layer in the EDS profile (b). 

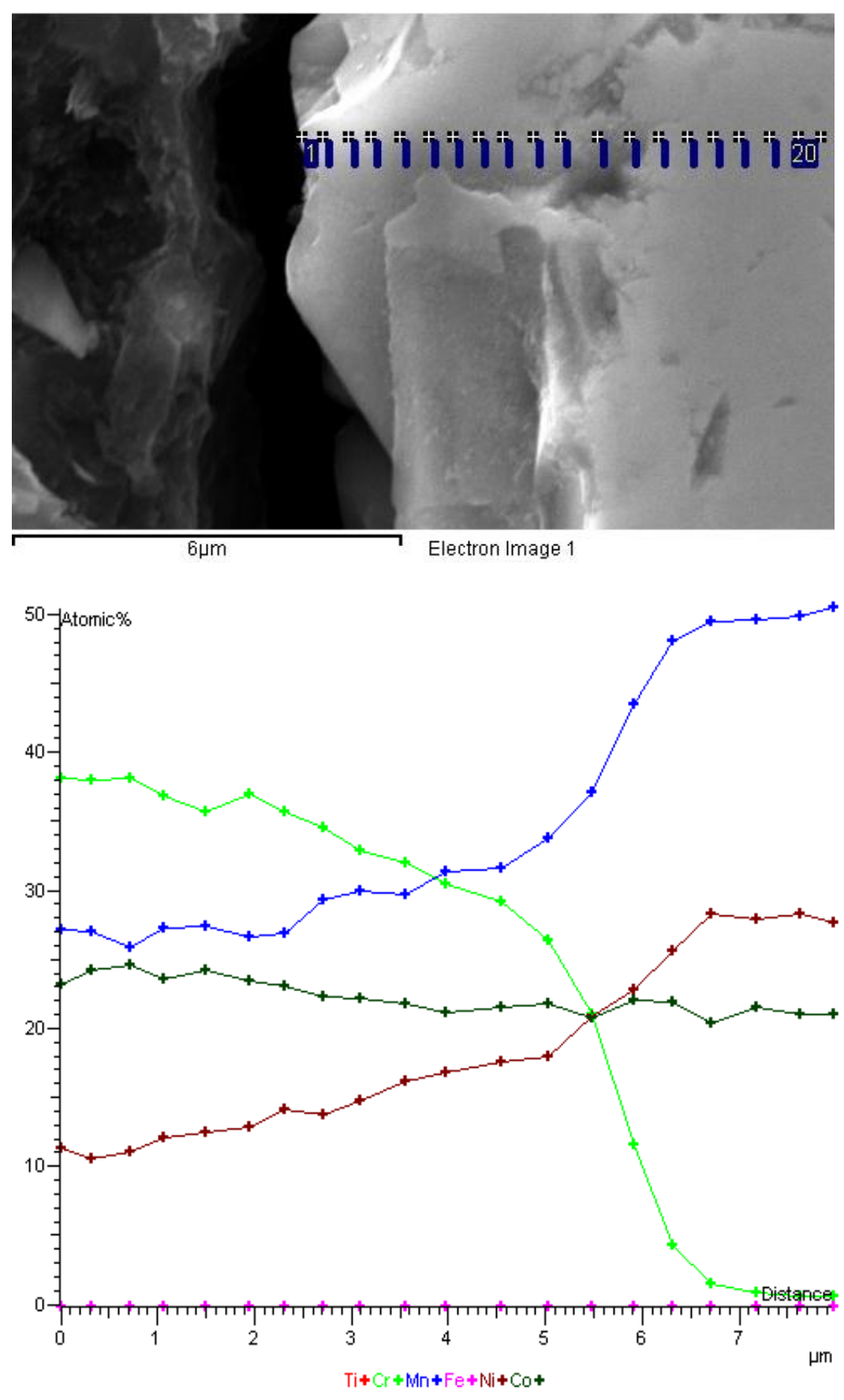

Figure 43.The cross section of the $\mathrm{Mn}_{1.5} \mathrm{CO}_{0.6} \mathrm{Ni}_{0.9} \mathrm{O}_{4}$ pellet that was in contact with chromia scale (a) and the corresponding elemental profile showing high chromium spinel formation (b) 

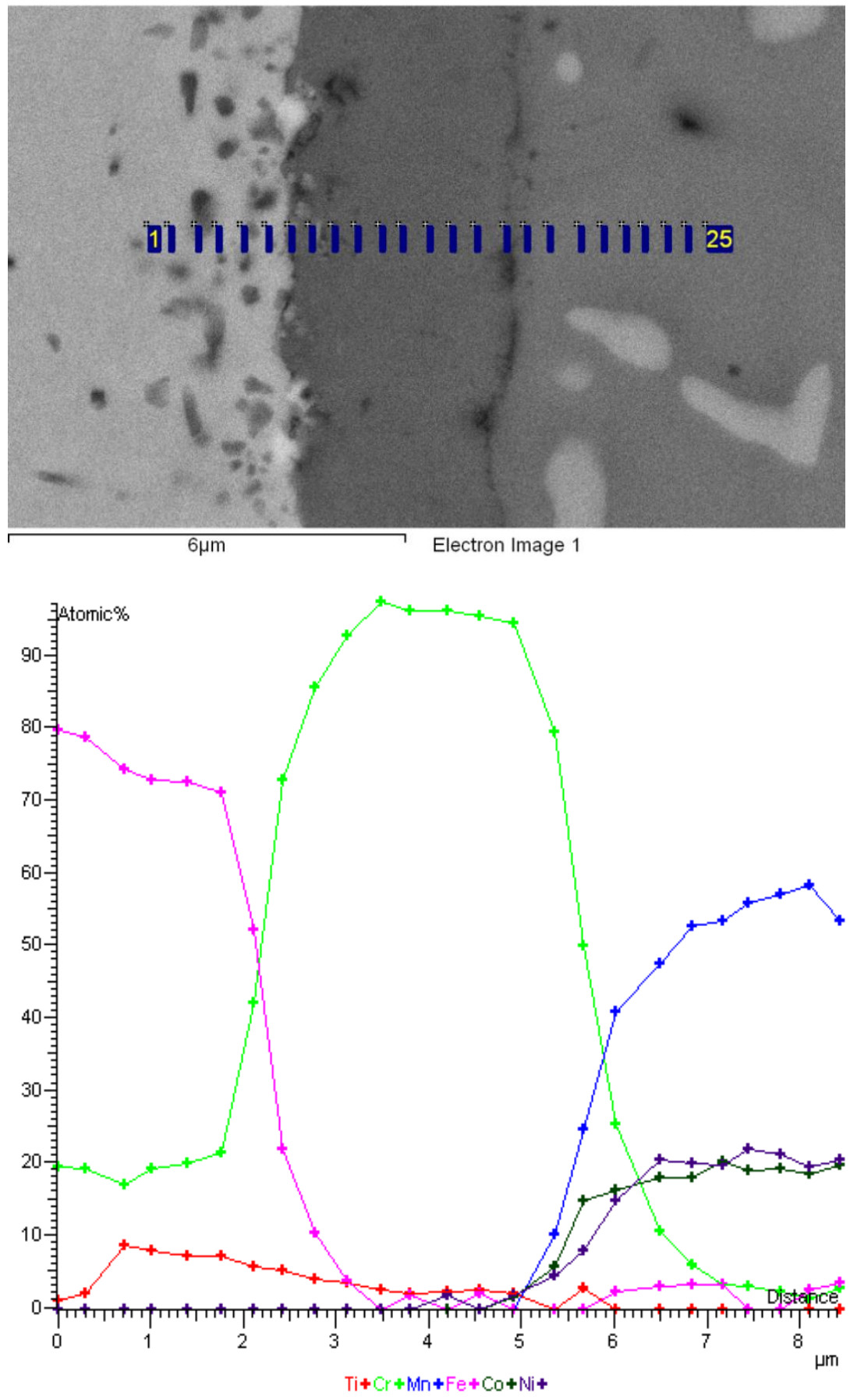

Figure 44. Interface of the SS $441-\mathrm{Mn}_{1.5} \mathrm{Co}_{0.6} \mathrm{Ni}_{0.9} \mathrm{O}_{4}$ diffusion couple after $100 \mathrm{~h}$ at $900^{\circ} \mathrm{C}$ showing good adhesion (a) and the absence of high chromium spinel in the EDS profile (b) 
The gap size needed to allow nucleation of the high chromium spinel phase will likely depend on temperature. At high temperatures, rapid growth of the chromia scale may close the gap faster than at low temperatures. This is evident in the results above, since a high-chromium scale was consistently observed in the diffusion couples heat treated at $800^{\circ} \mathrm{C}$. However, at $900^{\circ} \mathrm{C}$ the high chromium spinel phase was observed only for large gaps indicating that the relatively high growth rate of chromia scale could close small gaps and inhibit nucleation of the spinel phase.

To understand the reason for different reaction layer characteristics observed in the case of the spinel/alloy diffusion couples at $800^{\circ} \mathrm{C}$ and $900^{\circ} \mathrm{C}$ another experiment was performed. In this case an undoped spinel $\left(\mathrm{Mn}_{1.5} \mathrm{CO}_{1.5} \mathrm{O}_{4}\right) /$ alloy diffusion couple was heat treated at $800^{\circ} \mathrm{C}$ for 100 hours followed by 100 hours at $900^{\circ} \mathrm{C}$. The interphase of the diffusion couple (Figure 45) contains a thick chromia scale and the absence of a high-chromium spinel region, as in the case of the spinel alloy diffusion couple at $900^{\circ} \mathrm{C}$. This indicates that the high chromium spinel layer formed at $800^{\circ} \mathrm{C}$ is transformed at $900^{\circ} \mathrm{C}$. Interestingly the thickness of the chromium scale $(\sim 3 \mu \mathrm{m})$ is closer to the total thickness of $\mathrm{Cr}_{2} \mathrm{O}_{3}$ scale and high chromium spinel region in the spinel/alloy diffusion couple after $800^{\circ} \mathrm{C}$ for 100 hours (Figure 38).

\section{Reaction Mechanism}

The high-chromium spinel phase is consistently formed in diffusion couples between $\mathrm{Cr}_{2} \mathrm{O}_{3}$ and $(\mathrm{Mn}, \mathrm{Co})_{3} \mathrm{O}_{4}$ at $800-1200^{\circ} \mathrm{C}$, but is not reported in alloys with $(\mathrm{Mn}, \mathrm{Co})_{3} \mathrm{O}_{4}$ coatings, which should be similar since a chromia scale forms between the alloy and coating. The results in this project on diffusion couples between ferritic stainless steel and $(\mathrm{Mn}, \mathrm{Co})_{3} \mathrm{O}_{4}$ show that the high-chromium spinel phase forms in some cases but not others. The formation of the high-chromium spinel phase appears to be associated with a gap present at the beginning of the diffusion experiments. The high-chromium spinel phase is present after 100 hours at $800^{\circ} \mathrm{C}$, but not at $900^{\circ} \mathrm{C}$. Previous results indicate that the high-chromium spinel phase is stable to $1200^{\circ} \mathrm{C}$, so this is not likely a thermodynamic effect, but could be explained by the more rapid scale growth at $900^{\circ} \mathrm{C}$ filling the gap and preventing formation of the high-chromium phase. However, the high-chromium layer was also not present in a diffusion couple annealed for 100 hours at $800^{\circ} \mathrm{C}$ and then 100 hours at $900^{\circ} \mathrm{C}$, which suggests that the high-chromium spinel phase may form and then disappear. 

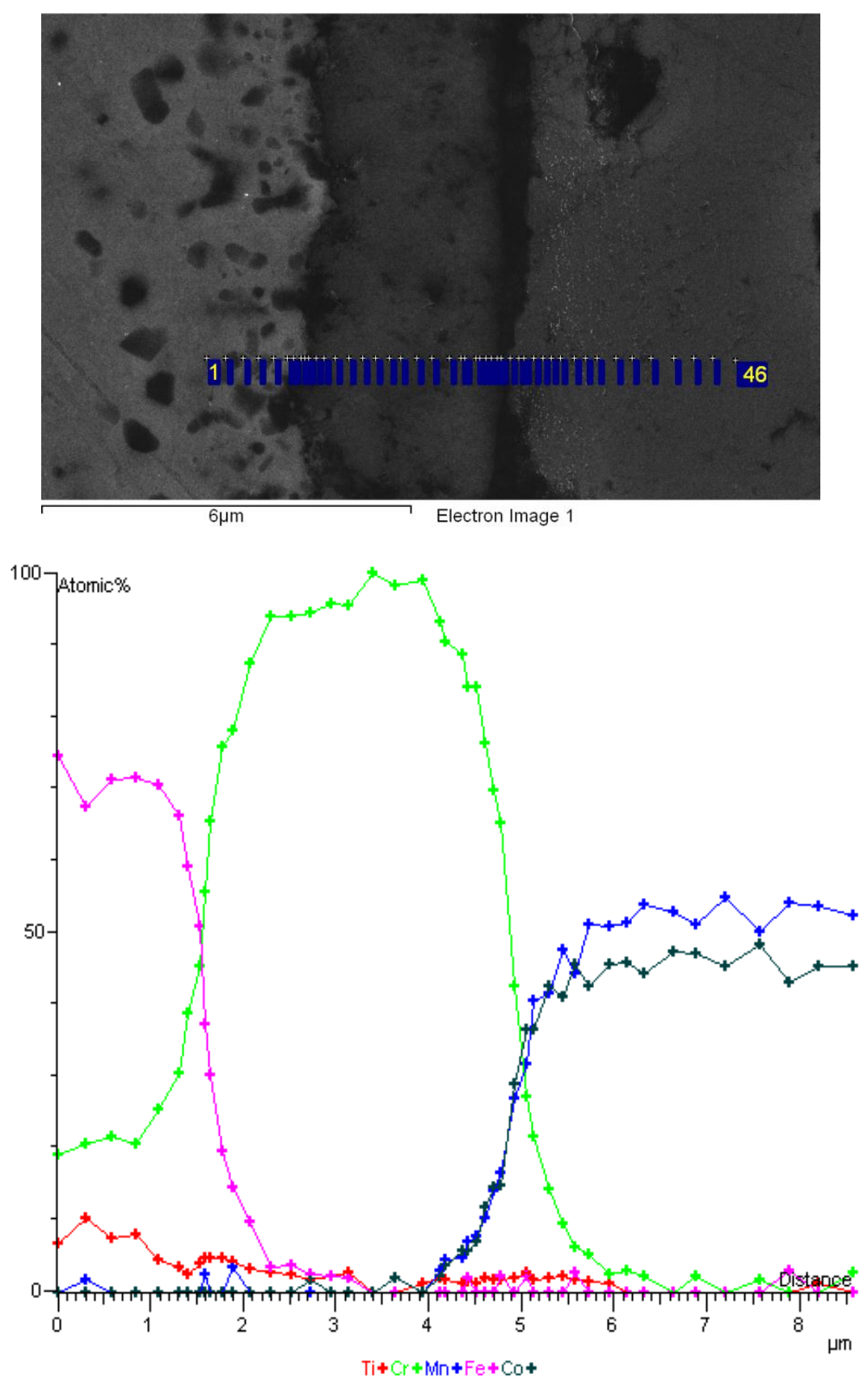

Figure 45. The interface of the undoped spinel/alloy diffusion couple after $800^{\circ} \mathrm{C}-100 \mathrm{~h}$ and $900^{\circ} \mathrm{C}-$ $100 \mathrm{~h}$ treatment (a), the line profile showing a thick chromia scale and absence of high chromium spinel layer. 
To understand this unexpected behavior it is helpful to separate the process into two parts. Figure 46 a illustrates the oxidation of an uncoated stainless steel alloy in which the growth of the chromia scale is generally attributed to outward chromium diffusion by chromium vacancies, which are formed when new chromia is formed on the scale surface. At the same time chromium is vaporized from the surface by the oxidation of $\mathrm{Cr}_{2} \mathrm{O}_{3}$ to $\mathrm{Cr}^{6+}$-containing species, such as $\mathrm{CrO}_{3}$ or $\mathrm{CrO}_{2}(\mathrm{OH})_{2}$. Figure $46 \mathrm{~b}$ illustrates the reactions that occur in diffusion couples between $(\mathrm{Mn}, \mathrm{Co})_{3} \mathrm{O}_{4}$ and $\mathrm{Cr}_{2} \mathrm{O}_{3}$ leads where a high-chromium spinel is formed at temperatures from $800-1200^{\circ} \mathrm{C}$. Although, a gap is not intentionally added, the poor sinterability of chromia results in a gap and the growth mechanism has been shown to be similar to cases in which chromium is supplied by vapor phase transport and a high-chromium spinel grows by diffusion of $\mathrm{Mn}$ and $\mathrm{Co}$ through the reaction layer. In the case of the alloy-(Mn,Co $)_{3} \mathrm{O}_{4}$ diffusion couples described above, the chromia scale is the source of chromium, so if a gap is present, the situation can be described by Figure 46c. In this case the growth of chromia from the alloy and the growth of high-chromium spinel from the spinel oxide pellet will fill the gap, at which point the growth mechanism must change as illustrated in Figure $46 \mathrm{~d}$. Chromia could grow at the expense of the high- $\mathrm{Cr}$ spinel or the high-Cr spinel could grow at the expense of chromia, but not both. The apparent disappearance of the high-chromium layer after annealing at $800^{\circ} \mathrm{C}$ for 100 hours and $900^{\circ} \mathrm{C}$, suggests the former case. The most reasonable explanation is that this, apparently thermodynamically-stable, phase is not present, and can be eliminated if formed intermittently, because it is consumed by the chromia scale and "dissolves" into the spinel phase due to diffusion of chromium.

An important implication of this growth mechanism is that the chromia scale is both growing as chromium from the alloy is being oxidized and also being consumed as chromium diffuses into the spinel coating. At steady-state it is possible that the thickness of the chromia layer could remain relatively constant. Since the area specific resistance (ASR) is likely dominated by this layer, the ASR may reach a constant value. Such behavior has been observed in a recent reports indicating that the ASR becomes constant after long exposure times (e.g. 5,000-18,000 hours) [24]. 


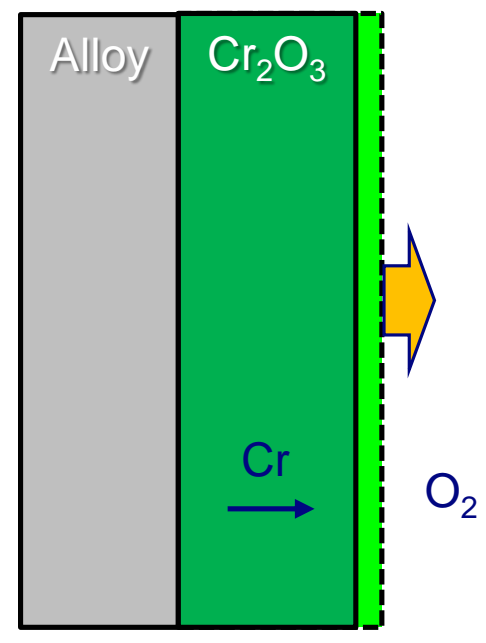

a Growth of chromia on uncoated alloy.

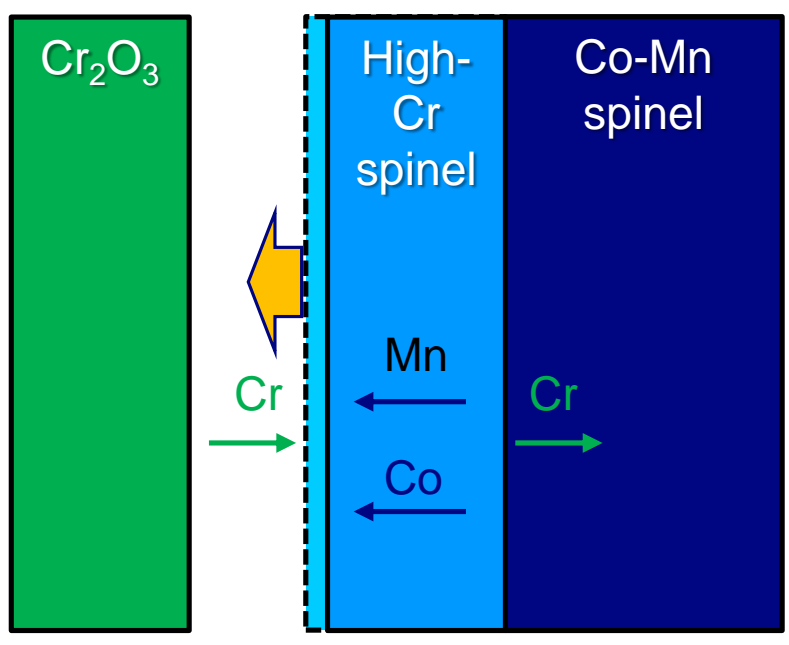

b. Growth of high-Cr spinel during reaction between chromia and Mn-Co spinel.

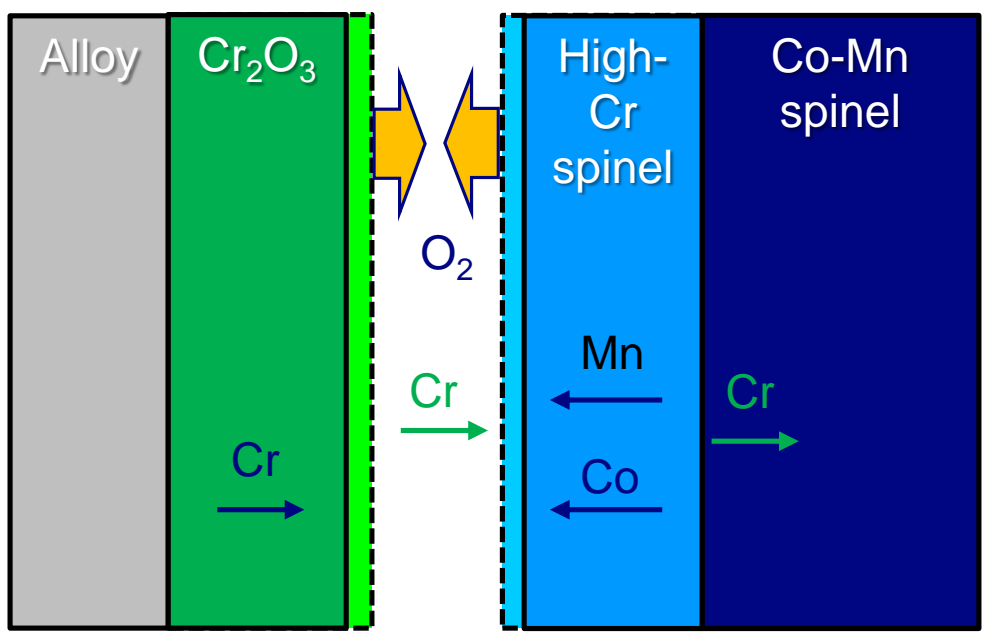

c. Reaction at alloy-spinel diffusion couple with gap.

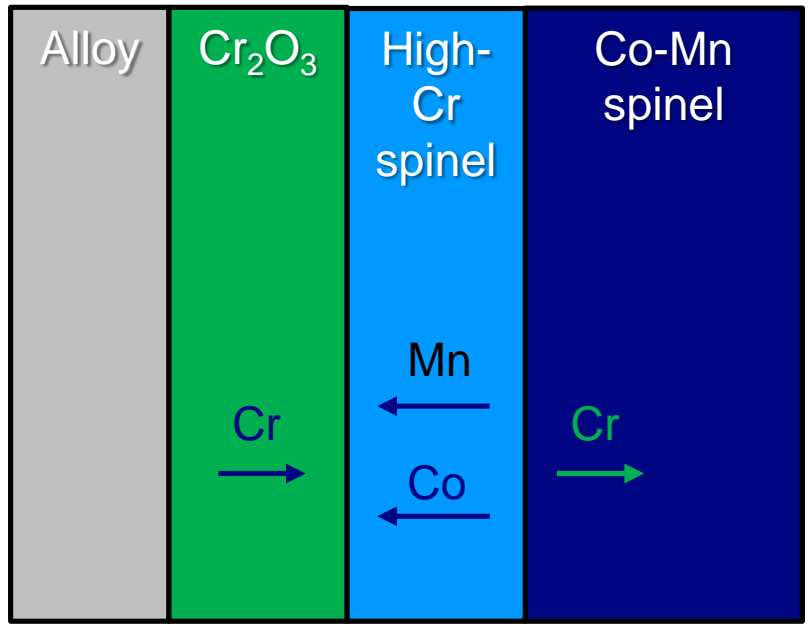

d. Diffusion couple after gap is filled.

Figure 46. Model for disappearance of high-chromium spinel phase. 


\section{Low-Cr Alloys}

In addition to evaluating the coating materials, the possibility of using lower chromium content in the alloy was investigated. A spinel oxide is typically present on the scale formed during oxidation of ferritic stainless steels containing manganese as an alloying addition and when the alloy is coated with a $(\mathrm{Mn}, \mathrm{Co})_{3} \mathrm{O}_{4}$ the scale and coating merge together. To evaluate if this structure will allow for a lower chromium content in the alloy, a series of experimental alloys containing the alloying additions in AISI 441 with varying chromium contents were prepared by Allegheny Technologies Inc. The compositions of these experimental alloys are summarized in Table 5. Some of the alloys were coated with $\mathrm{Mn}_{1.5} \mathrm{Co}_{1.5} \mathrm{O}_{4}$ at Pacific Northwest National Laboratory (PNNL) using a slurry coating process.

\begin{tabular}{|c|c|c|c|c|c|c|}
\hline \multirow{2}{*}{ Alloy } & \multicolumn{7}{|c|}{ Concentration (wt\%) } \\
\cline { 2 - 7 } & $\mathrm{Fe}$ & $\mathrm{Cr}$ & $\mathrm{Mn}$ & $\mathrm{Si}$ & $\mathrm{Ti}$ & $\mathrm{Nb}$ \\
\hline H52 & Bal. & 13 & 0.3 & 0.4 & 0.2 & 0.4 \\
\hline H53 & Bal. & 15 & 0.3 & 0.4 & 0.2 & 0.4 \\
\hline H54 & Bal. & 17 & 0.3 & 0.4 & 0.2 & 0.4 \\
\hline H55 & Bal. & 18 & 0.3 & 0.4 & 0.2 & 0.4 \\
\hline AISI 441 & Bal. & 18 & 0.4 & 0.3 & 0.2 & 0.5 \\
\hline
\end{tabular}

The oxidation resistances of coated and uncoated alloys were evaluated with both cyclic and isothermal exposures to air at $800^{\circ} \mathrm{C}$. The results of 25 -hour cyclic exposures are shown in Figure 47. The coated alloys exhibited a large initial weight gain, which was presumably due to re-oxidation of cobalt that was formed during the final sintering of the coating in a reducing atmosphere. The parabolic rate constants were determined by fitting the results beginning with 50-hour exposures and are summarized in Figure 48. The parabolic rate constant does not appear to vary significantly with chromium content. However, the parabolic rate constants for the experimental alloys are significantly higher than that measured for AISI 441. These differences are presumably related to the small production sizes in the experimental alloys, as compared to commercial steels, but the specific cause for the difference is not clear. 


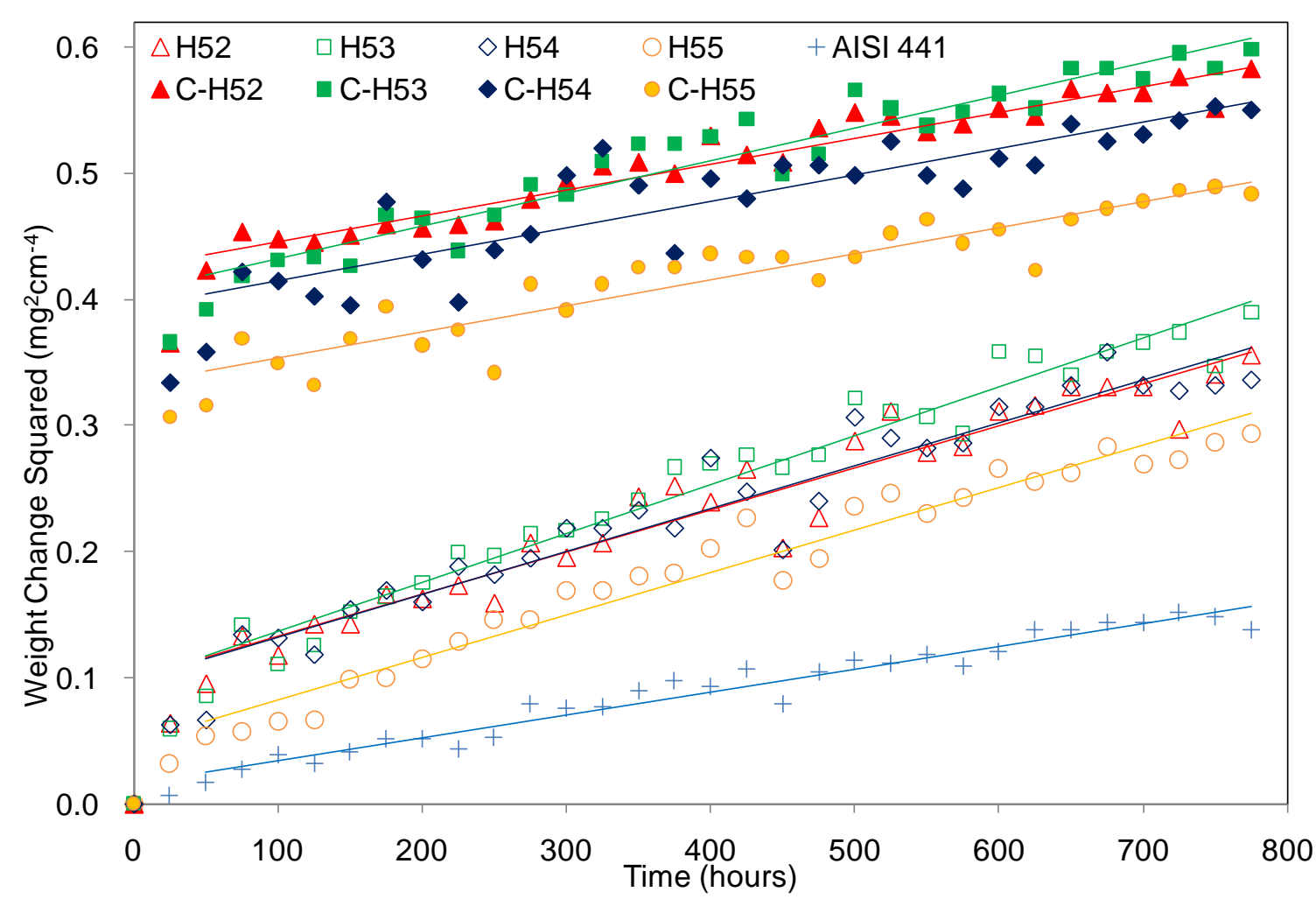

Figure 47. Cyclic oxidation behavior of coated and uncoated experimental alloys in air at $800^{\circ} \mathrm{C}$.

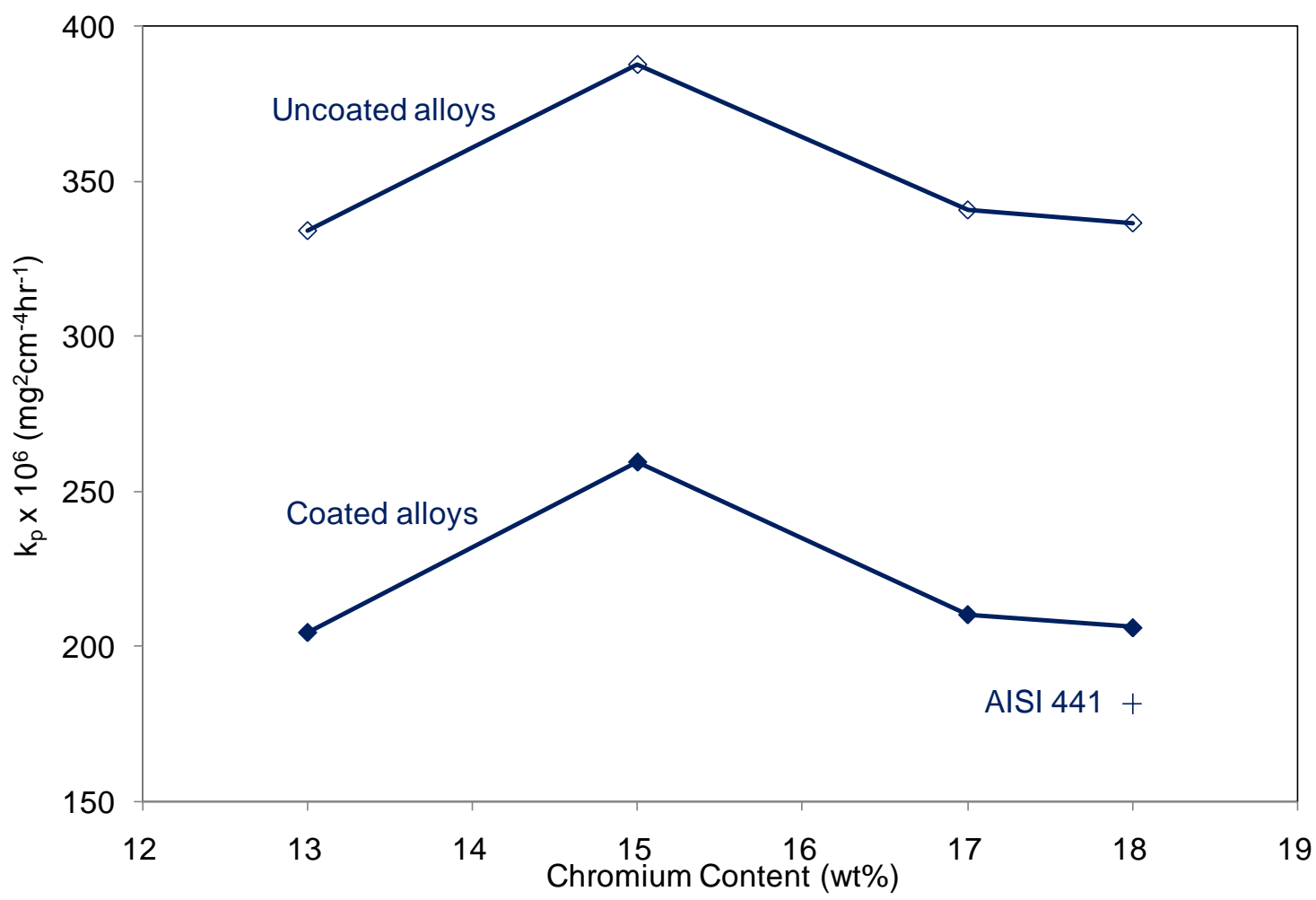

Figure 48. Parabolic rate constants for cyclic oxidation of coated and uncoated experimental alloys in air at $800^{\circ} \mathrm{C}$ for data shown in Figure 3. 
A scanning electron microscope micrograph of the cross-section of coated H52 after an isothermal exposure of 800 hours at $800^{\circ} \mathrm{C}$ in air is shown in Figure 49a. The concentration gradients as determined by EDS are shown in Figure 49b. Figure 49 is for the alloy containing $13 \% \mathrm{Cr}(\mathrm{H} 52)$, but the features were similar for other chromium contents. There appears to be little or no high-chromium spinel phase at the interface, which is consistent with the reaction model discussed above. As the chromium content increased in the spinel phase, the Co:Mn ratio increased, which is presumably related to site occupancy preference as chromium and manganese have stronger preference for the octahedral site as compared to cobalt. Titanium was sometimes observed at the alloy-scale interface, while niobium was typically not present in the reaction layer.

The general features of the reaction layer were similar for different chromium contents, but there were differences in the amount of the reaction. Figure 50 shows the reaction layer thickness as determined by the average of 50 measurements. Although the standard deviations of the measurements overlap, a student t-test indicates that the thicknesses for $13-15 \% \mathrm{Cr}$ were statistically different from those of $17-18 \% \mathrm{Cr}$ to greater than $99 \%$ confidence.

Some of the alloys that were coated with $\mathrm{Mn}_{1.5} \mathrm{Co}_{1.5} \mathrm{O}_{4}$ at $\mathrm{PNNL}$ were exposed to air at $800^{\circ} \mathrm{C}$ for 1600 hours. One notable effect of chromium content, shown in Figure 51, was that a significant amount of iron was observed on the surface of the coating for the alloys with low chromium contents (13 and 15 $\% \mathrm{Cr}$ ), while iron was not observed for higher chromium contents (17 and $18 \% \mathrm{Cr}$ ).

The alloys were exposed to dual-atmosphere conditions, in which one side of the alloy was exposed to air and the other side to argon with $5 \%$ hydrogen. In each of these experiments a control sample that was exposed to air on all sides was place in the reaction chamber to provide comparison for evaluating the effect of the dual-atmosphere exposure. Figure 52a shows that the iron content in the samples exposed to a dual atmosphere ("air side") is higher than that in the sample exposed only to air ("control"), which is consistent with other reports in the literature [25-27]. The surfaces of the oxide scales contained a network of ridges, which corresponded to the alloy grain boundaries. Figure 52b shows that the manganese concentration in these ridges is higher for both exposure conditions, which suggests that the grain boundaries in the alloy provide a path for manganese diffusion.

In summary, these results indicate that $17-18 \% \mathrm{Cr}$ is needed to provide good performance for SOFC applications even if an $(\mathrm{Mn}, \mathrm{Co})_{3} \mathrm{O}_{4}$ coating is applied to the surface. 

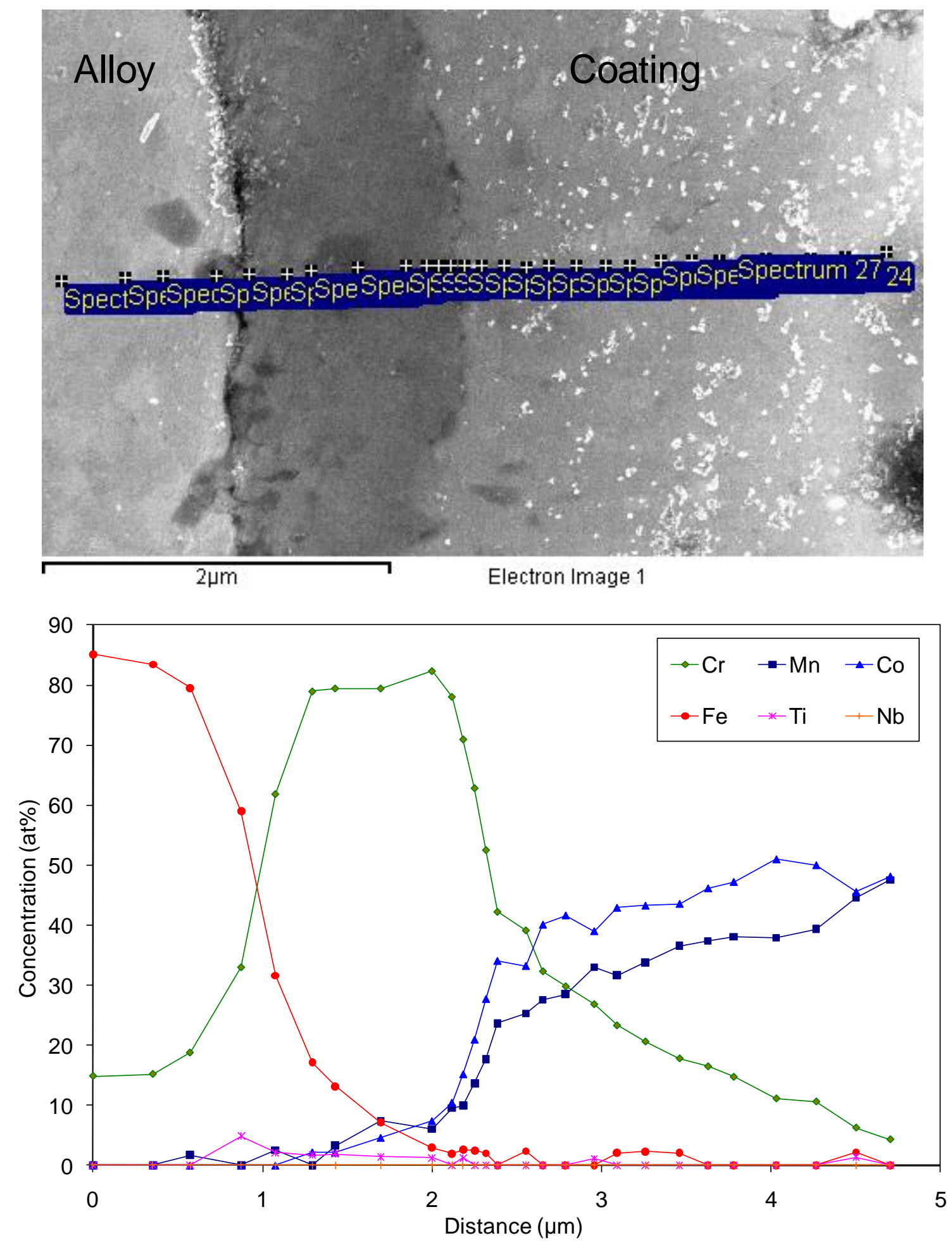

Figure 49. SEM cross section and concentration gradients at the interface between $\mathrm{H} 52(13 \% \mathrm{Cr})$ and the $\mathrm{Mn}_{1.5} \mathrm{Co}_{1.5} \mathrm{O}_{4}$ coating after 800 hours at $800^{\circ} \mathrm{C}$ in air. 


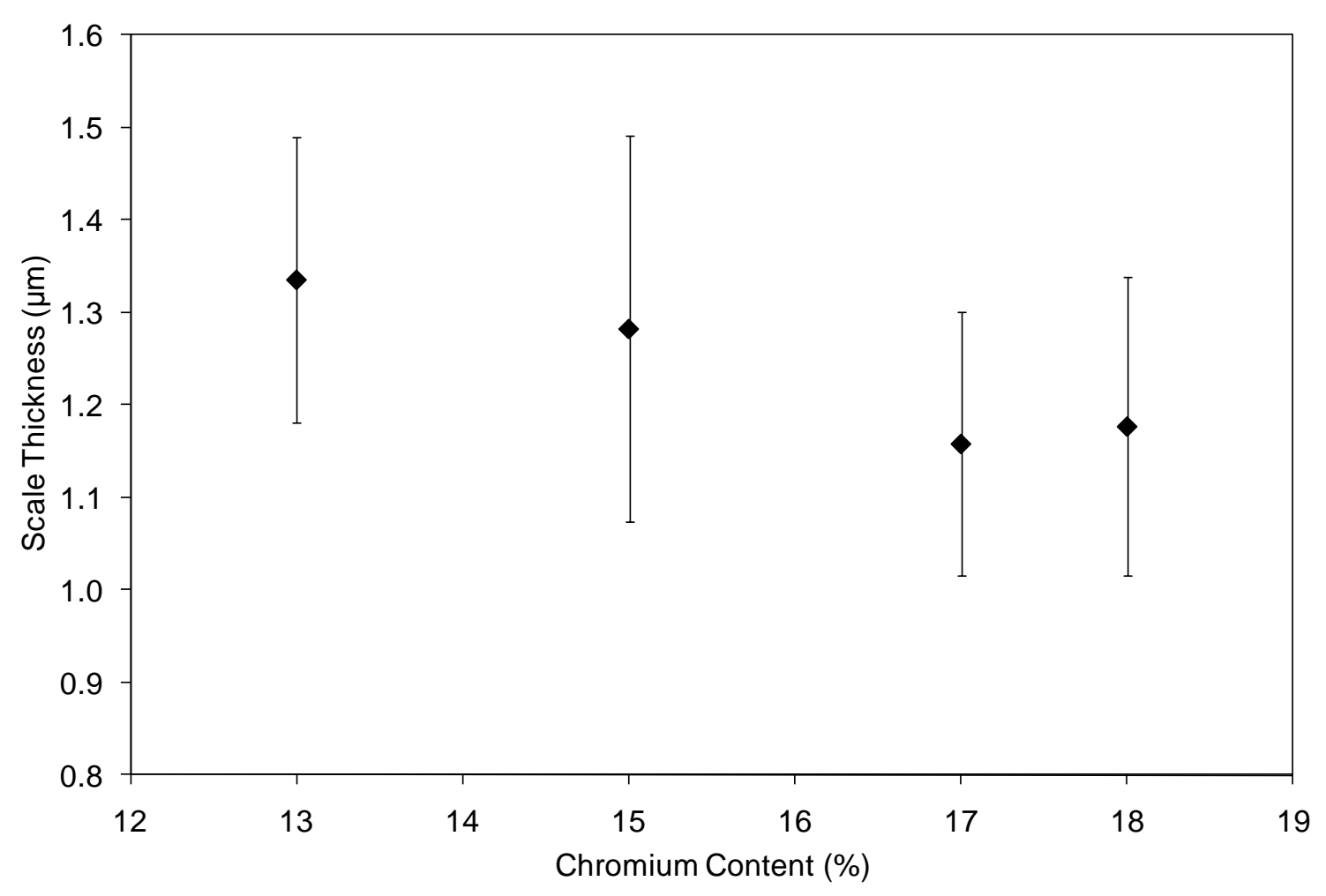

Figure 50. Thicknesses of reaction layers between experimental alloys and $\mathrm{Mn}_{1.5} \mathrm{Co}_{1.5} \mathrm{O}_{4}$ coatings after 800 hours at $800^{\circ} \mathrm{C}$ in air. The error bars represent the standard deviation of 50 measurements.

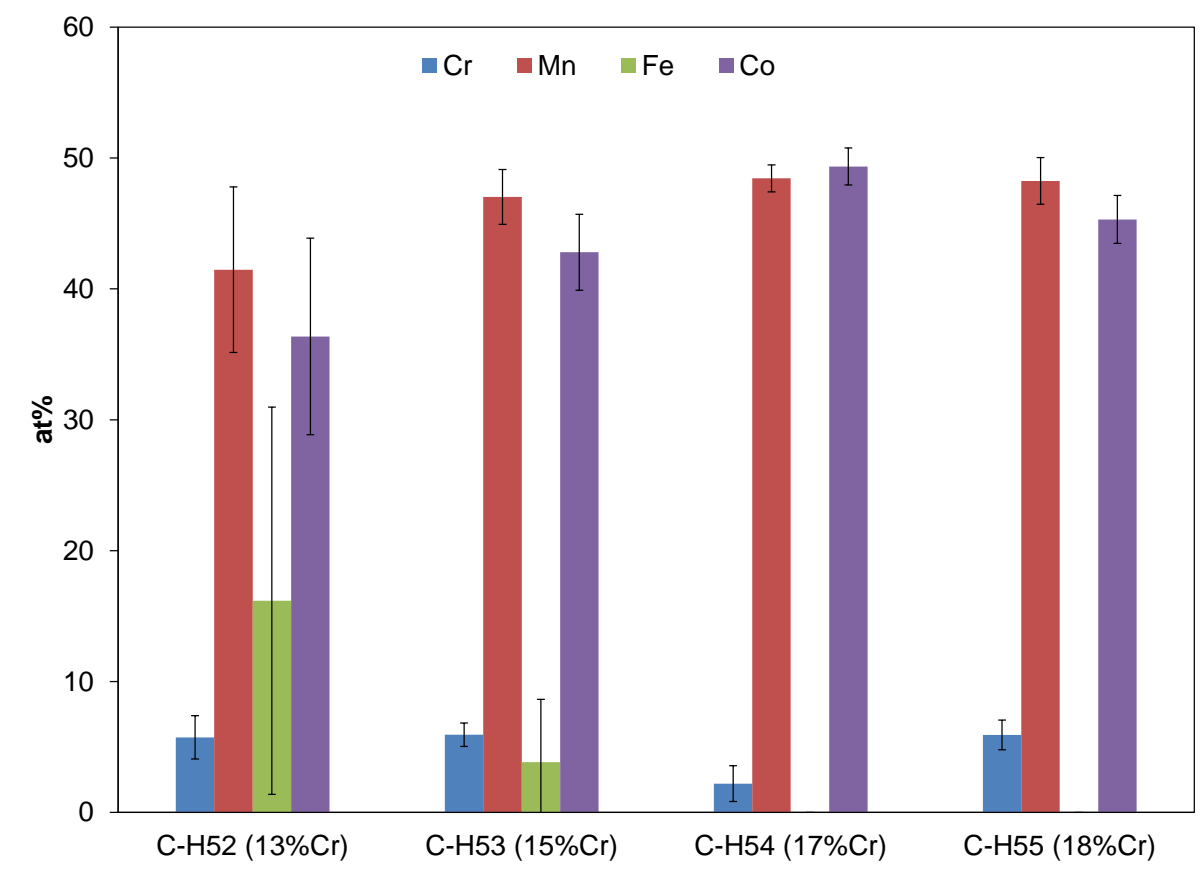

Figure 51. Surface composition of $\mathrm{Mn}_{1.5} \mathrm{Co}_{1.5} \mathrm{O}_{4}$-coated alloys with $13-18 \% \mathrm{Cr}$ after 1600 hours in air at $800^{\circ} \mathrm{C}$. 

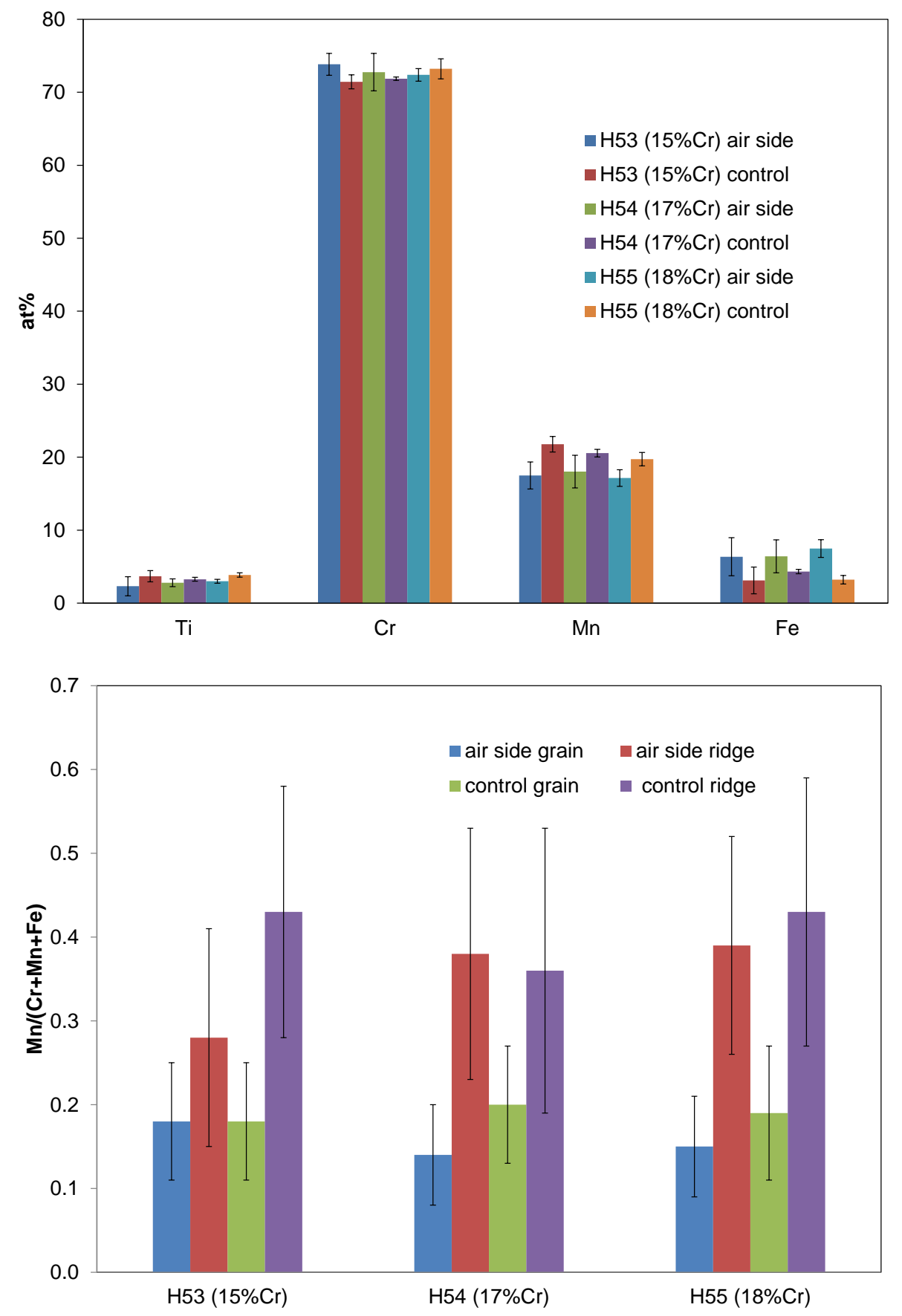

Figure 52. Surface composition (a) and manganese and manganese proportion (b) in scale formed on uncoated alloys with $13-18 \% \mathrm{Cr}$ after 200 hours in air at $800^{\circ} \mathrm{C}$ under dual atmosphere (air side) or single atmosphere (control) exposures. 


\section{References}

1. Y. Larring and T. Norby, J. Electrochem. Soc. 147, 3251 (2000).

2. Z. Yang, G.-G. Xia, G.D. Maupin and J.W. Stevenson, Surf. Coating Tech. 201, 4476 (2006).

3. M.R. Bateni, P. Wei, X. Deng and A. Petric, Surf. Coating Tech. 201, 4677 (2007).

4. M.J. Garcia-Vargas, M. Zahid, F. Tietz and A. Aslanides, Electrochem. Trans. 7, 2399 (2007).

5. H. Kurokawa, C.P. Jacobson, L.C. DeJonghe and S.J. Visco, Solid State lonics 178, 287 (2007).

6. C. Collins, J. Lucas, T.L. Buchanan, M. Kopczyk, A. Kayani, P.E. Gannon, M.C. Deibert, R.J. Smith, D.-S. Choi and V.I. Gorokhovsky, Surf. Coating Tech. 201, 4467 (2006).

7. Z. Yang, G.-G. Xia, H.-H. Li and J.W. Stevenson, Int. J. Hydrogen Energy 32, 3648 (2007).

8. Z. Yang, G. Xia and J.W. Stevenson, Electrochem. Solid-State Lett. 8, A168 (2005).

9. A. Navrotsky, O.J. Kleppa, J. Inorg. Nucl. Chem. 29, 2701 (1967).

10. Z. Yang, G. Xia, S. P. Simmer, J. W. Stevenson, J. Electrochem. Soc. 152, A1896 (2005).

11. A. Purwanto, A. Fajar, H. Mugirahardjo, J.W. Fergus and K. Wang, J. Appl. Cryst, 43, 394 (2010).

12. X. Chen, P.Y. Hou, C.P. Jacobson, S.J. Visco and L.D. De Jonghe, Solid State Ionics 176, 425 (2005).

13. T. Sasamoto, N. Sumi, A. Shimaji, O. Yamamoto, and Y. Abe, J. Mater. Sci. Soc. Jpn. 33[1], 32 (1996).

14. K. Hauff and J. Block, Z. Phys. Chem., 198, 232 (1951).

15. A. Holt and P. Kofstad, Solid State lonics, 69, 127 (1994).

16. W.C. Hagel and A.U. Seybolt, J. Electrochem. Soc., 108, 1146 (1961).

17. H. Nagai, T. Fujikawa, K.-i. Shoji, Trans. Japan Inst. Met., 24, 581 (1983).

18. W. Qu, L. Jian, J.M. Hill and D.G. Ivey, J. Power Sources, 153, 114 (2006).

19. T. Uehara, A. Toji, K. Inoue, M. Yamaguchi, T. Ohno, in S.C. Singhal, M. Dokiya (Eds.), Solid Oxide Fuel Cells VIII-Electrochem. Soc. Proc. PV 2003-07 (The Electrochemical Society, Pennington, NJ, 2003) p. 914.

20. M. Ueda, H. Taimatsu, A.J. McEvoy (Ed.), European Solid Oxide Fuel Cell Forum Proceedings, Vol. 2 (The European Fuel Cell Forum, Lucerne, Switzerland, 2000) p. 837.

21. J. Pirón-Abbellán, V. Shemet, F. Tietz, L. Singheiser, W.J. Quadakkers, A. Gil, H. Yokokawa, S.C. Singhal (Eds.), Solid Oxide Fuel Cells VII-Electrochem. Soc. Proc. PV 2001-16 (The Electrochemical Society, Pennington, NJ, 2001) p. 811.

22. J.W. Fergus, Mater. Sci. Eng. A 397[1-2], 271 (2005).

23. Figure 9127, Phase Diagrams for Ceramists (American Ceramics Society, Westerville, OH).

24. J.W. Stevenson, G.G. Xia, J.P. Choi, Y.S Chou, E.C. Thomsen, K.J. Yoon, R.C. Scott, X. Li and Z. Nie, Proc. $12^{\text {th }}$ Ann. SECA Workshop (DOE, 2011). 
25. Z.G. Yang, M.S. Walker, P. Singh and J.W. Stevenson, Electrochem. Solid-State Lett. 6, B35 (2003).

26. Z. Yang, G.-G. Xia, M. S. Walker, C.-M. Wang, J.W. Stevenson and P. Singh, Int. J. Hydrogen Energy, 32, 3770 (2007).

27. J. Rufner, P. Gannon, P. White, M. Deibert, S. Teintze, R. Smith and H. Chen , Int. J. Hydrogen Energy, 33, 1392 (2008), 